ERICA CORINA DA SILVA

Dupla modificação química do amido de mandioca com potencial uso como biomaterial

São Paulo

2019 

ERICA CORINA DA SILVA

\section{Dupla modificação química do amido de mandioca com potencial uso como biomaterial}

\section{Versão Corrigida}

Dissertação apresentada ao Programa de Pós-graduação em Engenharia Química da Escola Politécnica da Universidade de São Paulo para obtenção do título de Mestre em Ciências

Área de concentração: Engenharia Química

Orientadora: Dra. Carmen Cecilia Tadini

São Paulo

2019 

Autorizo a reprodução e divulgação total ou parcial deste trabalho, por qualquer meio convencional ou eletrônico, para fins de estudo e pesquisa, desde que citada a fonte.

Este exemplar foi revisado e corrigido em relação à versão original, sob responsabilidade única do autor e com a anuência do coordenador suplente do programa, Prof. Jorge Andrey Whilhelms Gut.

São Paulo, 18 de Dezembro de 2020

Assinatura do autor: rical Silua

Assinatura do coordenador suplente do programa:

\section{Catalogação-na-publicação}

\section{Silva, Erica}

Dupla modificação química do amido de mandioca com potencial uso como biomaterial / E. Silva -- versão corr. -- São Paulo, 2020. $136 \mathrm{p}$.

Dissertação (Mestrado) - Escola Politécnica da Universidade de São Paulo. Departamento de Engenharia Química.

1.Bioengenharia 2.Biomateriais 3.Polissacarídeos 4.Amido 5.Esterificação I.Universidade de São Paulo. Escola Politécnica. Departamento de Engenharia Química II.t. 

DEDICATÓRIA

A Elenilda Corina 



\section{AGRADECIMENTOS}

A minha orientadora Carmen Tadini pelos ensinamentos e pela oportunidade de crescimento.

A Bianca Maniglia, a Elizabeth Fernandes e ao Reinaldo Guidici pelo olhar apreciativo, pelas correções e sugestões no exame de qualificação.

A Fernanda Carli pelo companheirismo, foram muitas horas me ajudando no laboratório, e por me lembrar que sempre existe uma forma diferente de ver o mesmo problema.

A Auta Narjara pelo carinho e pela convivência.

A Tânia Shiga, a Larissa Castelo Branco e ao Davi Éber pelo apoio com as análises térmicas e com o tratamento dos dados.

Ao Paulo Moreira por toda a ajuda com a montagem experimental.

Ao Thiago Abreu pelo constante companheirismo, cuidado e carinho.

A Heloísa Ribeiro, Nilmara Spressola, Patrícia Metolina, Mariana Palacios, Mariana Paes, Natália Habib, Carla Ivonne, Lina Rayo, Cristiane Léis, Roberta Antunes, Robert Franzoi, Isabella Zamboni, Maria Guiliana Torraga, Thiago Hewer e Ana Paula Silvestre pelos momentos em que se fizeram presente.

Aos professores Rômulo Ando, Dalva Farias e Márcia Temperini do Laboratório de Espectroscopia Vibracional Hans Stammreich por terem disponibilizado os equipamentos para as análises de infravermelho e de Raman.

Aos professores Aldo Tonso, Pedro Alcântara e a Maria Robustillo do Laboratório de Engenharia de Bioprocessos por terem disponibilizado a infraestrutura do laboratório e o microcalorímetro para as análises térmicas.

Aos funcionários do LEA e do FORC por toda ajuda.

À Fundação de Amparo à Pesquisa do Estado de São Paulo pela oportunidade de treinamento em análise térmica diferencial (Processo 2017/22260-5). 

"One accurate measurement is worth a thousand expert opinions." Grace B. M. Hopper 


\section{RESUMO}

SILVA, E C. Dupla modificação química do amido de mandioca com potencial uso como biomaterial. 2019. 136 p. Dissertação (Mestrado em Engenharia Química) - Escola Politécnica, Universidade de São Paulo, São Paulo, 2019.

A modificação química é a chave para transformar polissacarídeos em biomateriais. Amido modificado para aplicações biomédicas é sintetizado em condições nas quais a quantidade de grupos funcionais inseridos nas moléculas dever ser limitada e a estrutura do grânulo deve ser preservada. Entretanto, a literatura trata o sistema de síntese química como caixa-preta. Este trabalho questionou essa abordagem por meio da síntese de derivados de amido de mandioca em uma montagem experimental capaz de monitorar o meio de reação e de controlar o pH por intermédio de microcontroladores. $\mathrm{O}$ amido de mandioca nativo foi reticulado em quatro condições distintas, variando $\circ \mathrm{pH}$ e a proporção de trimetafosfato trisódio por amido. Os derivados reticulados foram então acetilados com anidrido acético nas mesmas condições de reação. Os parâmetros de gelatinização foram estimados por microcalorimetria exploratória diferencial e as mudanças na estrutura molecular foram avaliadas por espectroscopia vibracional. Os resultados demonstraram que os ânions fosfato interagem com as moléculas do amido e alteram o padrão de inchamento. A temperatura e a entalpia de gelatinização dos derivados reticulados, em média, foram iguais e os espectros vibracionais semelhantes. A temperatura de gelatinização dos derivados acetilados foi menor que a temperatura de gelatinização dos derivados reticulados e a entalpia de gelatinização também foi menor, mas esta diferença não alcançou significância estatística. Concluiu-se que as condições do meio de reticulação comprometem a estrutura do grânulo, levando à gelatinização e que as moléculas do amido não reticulam nas condições estudadas. Além disso, a estabilidade térmica do grânulo diminuiu quando as moléculas estavam acetiladas devido ao abaixamento do ponto de fusão da amilopectina, por sua vez, causado pela presença de moléculas hidrolisadas na fase fundida. No mais, a unidade química montada assegurou a repetibilidade das condições de síntese dos derivados de amido de mandioca.

Palavras-Chave: Bioengenharia. Biomateriais. Polissacarídeos. Amido. Esterificação. 


\section{ABSTRACT}

\section{SILVA, E. C. Double-chemically modified cassava starch as potential biomaterial.}

2019. 136 p. Dissertação (Mestrado em Engenharia Química) - Escola Politécnica, Universidade de São Paulo, São Paulo, 2019.

Modification of polysaccharide macromolecules provides control over chemical functionality to fabricate biomaterials. Pharmaceutical grade starch derivatives are modified by appending a limited number of functional groups to starch molecules while curtailing granule rupture. The research into the chemical modification of starch approaches the chemical reaction system as a black box. This work challenged this approach by synthesizing modified cassava derivatives in an experimental assembly enabled by microcontrollers to monitor the reacting medium conditions and to control the $\mathrm{pH}$. Native cassava starch was cross-linked at four conditions varying the $\mathrm{pH}$ and the proportion of trisodium trimetaphosphate to starch. Subsequently, the cross-linked derivatives were acetylated with acetic anhydride in the same reaction conditions. The gelatinization parameters were evaluated by differential scanning microcalorimetry and the structural changes were assessed by vibrational spectroscopy. It was observed anions phosphate interaction with starch molecules changed the granule swelling pattern. The gelatinization temperature and enthalphy, and the vibrational spectra of cross-linked derivatives did not differ. The gelatinization temperature of acetylated derivatives was lower than the gelatinization temperature of cross-linked derivatives, and the enthalpy was also lower, but this difference did not reach statistical significance. These findings are associated with activity of anions phosphate that can disrupt gelatinization and with lack of cross-linked bonds between starch molecules. It can be inferred the underlying cause of lower thermal stability of acetylated derivative granules was the melting point depression of amylopectin owing to hydrolized molecules present in the melted phase. Furthermore, the automated experimental assembly prevented losses of experiments and guaranteed batch to batch reproducibility.

Keywords: Bioengineering. Biomaterials. Polysaccharides. Starch. Esterification. 


\section{LISTA DE FIGURAS}

Figura 1 - Modificação química do amido para a síntese do hidroxietilamido utilizado como expansor de plasma do sangue.

Figura 2 - Estrutura molecular da amilopectina (a), mostrando um ponto de ramificação e da isomaltose seu dissacarídeo básico. Estrutura molecular da amilose (b), mostrando sua estrutura linear e da maltose seu dissacarídeo básico.

Figura 3 - Grânulos de amido vistos em um microscópio de luz polarizada, mostrando os padrões de interferência cruzada. Magnificação 250x.

Figura 4 - Esquema de uma molécula de amilopectina mostrando as ramificações das cadeias que originam as regiões cristalinas....

Figura 5 - Camada de crescimento das moléculas de amilopectina no amido de mandioca de acordo com o modelo backbone de organização.

Figura 6 - Esquema de comparação das características estruturais das macromoléculas de amido.

Figura 7- Relação entre o inchamento do grânulo e o sinal de birrefringência da suspensão do amido de trigo-água (1:2) aquecida a taxa de $10^{\circ} \mathrm{C} \mathrm{min}^{-1}$.

Figura 8 - Esquema ilustrativo da reticulação e posterior acetilação do amido de mandioca.

Figura 9 - Tela de interface do programa de monitoramento da temperatura e do $\mathrm{pH}$ do meio de reação no LabVIEW.

Figura 10 - Desenho ilustrativo do sistema de reação para a síntese do amido de mandioca quimicamente modificado.

Figura 11 - Esquema do sistema de adição automática de anidrido acético.

Figura 12 - Esquema do sistema de controle do pH do meio de reação.......

Figura 13 - Esquema do novo sistema de controle do $\mathrm{pH}$ do meio de acetilação.

Figura 14 - Diagrama de blocos das etapas dos experimentos de reticulação do amido de mandioca nativo.

Figura 15 - Diagrama de blocos das etapas dos experimentos de acetilação do amido de mandioca reticulado. 
Figura 16 - Exemplo de deconvolução de uma transição exotérmica. .....

Figura 17 - Representação de dois sistemas de massas pontuais ligadas por molas executando movimento oscilatório.

Figura 18- Movimentos vibracionais das ligações químicas do grupo funcional (- $\mathrm{CH} 2-)$.

Figura 19 - Representação esquemática do caminho de um raio de luz infravermelha em um elemento de reflectância interna.

Figura 20 - Esquema identificando os tipos de espalhamento da luz quando um material é irradiado por um laser.

Figura 21 - Variação do pH (a) e da temperatura (b) do meio de reticulação em função do tempo de síntese do derivado reticulado $\mathrm{R}_{1}(\mathrm{pH}$ 10,0 e Rstmp:Agu 0,03).

Figura 22 - Variação do pH (a) e da temperatura (b) do meio de reticulação em função do tempo de síntese do derivado reticulado $\mathrm{R}_{4}(\mathrm{pH}$ 11,0 e Rstmp:Agu 0,08).

Figura 23 - Variação do pH (a) e da temperatura (b) do meio de reticulação em função do tempo de síntese do derivado reticulado $\mathrm{R}_{16}(\mathrm{pH}$ 11,0 e RstMP:Agu 0,08).

Figura 24 - Variação do pH (a) e da temperatura (b) do meio de acetilação em função do tempo de síntese do derivado acetilado $\mathrm{RA}_{1}(\mathrm{pH}$ 10,0 e RstMP:Agu 0,03).

Figura 25 - Variação do pH (a) e da temperatura (b) do meio de acetilação em função do tempo de síntese do derivado acetilado $\mathrm{RA}_{2}(\mathrm{pH}$ 11,0 e RstMP:Agu 0,03).

Figura 26 - Variação do pH (a) e da temperatura (b) do meio de acetilação em função do tempo de síntese do derivado acetilado $\mathrm{RA}_{15}(\mathrm{pH}$ 10,0 e Rstmp:Agu 0,08).

Figura 27 - Espectros normalizados de absorção no infravermelho do (a) amido de mandioca nativo e dos derivados reticulados a $\mathrm{pH} 10,0$ e Rstmp:Agu 0,03, e dos (b) derivados reticulados a pH 11,0 e $R_{\text {StMP:AGU }} 0,03$, e dos derivados (c) reticulados a pH 10,0 e

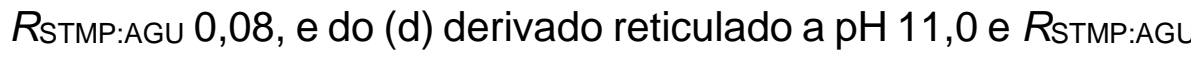
0,08 . 
Figura 28 - Comparação dos espectros deconvoluídos de absorção no infravermelho do amido de mandioca nativo nas faixas de frequência de (a) 1500 a $1100 \mathrm{~cm}^{-1}$, de (b) 1120 a 940) $\mathrm{cm}^{-1} \mathrm{e}$ de (c) 940 a $820 \mathrm{~cm}^{-1}$ e do derivado $\mathrm{R}_{1}$ (pH 10,0 e Rstmp:AGu 0,03) nas faixas de frequência de (d) $1500 \mathrm{a} 1100 \mathrm{~cm}^{-1}$, de (e) $1120 \mathrm{a}$ $940 \mathrm{~cm}^{-1}$ e de (f) 940 a $820 \mathrm{~cm}^{-1}$.

Figura 29 - Comparação dos espectros deconvoluídos de absorção no infravermelho do amido de mandioca nativo nas faixas de frequência de (a) 1500 a $1100 \mathrm{~cm}^{-1}$, de (b) 1120 a $940 \mathrm{~cm}^{-1}$ e de (c) 940 a $820 \mathrm{~cm}^{-1}$ e do derivado $R_{16}(\mathrm{pH} 11,0$ e Rstmp:AGu 0,08) nas faixas de frequência de (d) 1500 a $1100 \mathrm{~cm}^{-1}$, de (e) $1120 \mathrm{a}$ $940 \mathrm{~cm}^{-1}$ e de (f) 940 a $820 \mathrm{~cm}^{-1}$

Figura 30 - Espectros normalizados de absorção no infravermelho do (a) amido de mandioca nativo e dos derivados acetilados $(\mathrm{pH} 10,0$ e Rstmp:AGU 0,03), e dos (b) derivados acetilados (pH 11,0 e Rstmp:Agu 0,03), e dos (c) derivados acetilados (pH 10,0 e RStMP:AGU 0,08), e do (d) derivado acetilado $R_{16}(\mathrm{pH} 11,0$ e RSTMP:AGU 0,08).

Figura 31 - Comparação dos espectros deconvoluídos de absorção no infravermelho do derivado $\mathrm{RA}_{1}(\mathrm{pH} 10,0$ e RSTMP:AGU 0,03) na faixa de frequência de (a) 3900 a $1500 \mathrm{~cm}^{-1}$ e na faixa de frequência de (b) 1500 a $1100 \mathrm{~cm}^{-1}$ com os espectros do derivado $\mathrm{RA}_{16}(\mathrm{pH} 11,0$ e RSTMP:AGu 0,08$)$ na faixa de frequência de (c) 3900 a $1500 \mathrm{~cm}^{-1}$ e na faixa de frequência de (d) $1500 \mathrm{a}$ $1100 \mathrm{~cm}^{-1}$.

Figura 32 - Comparação dos espectros deconvoluídos de absorção no infravermelho na faixa de frequência de 1500 a $1100 \mathrm{~cm}^{-1}$ do (a) amido de mandioca nativo, do (b) derivado $\mathrm{RA}_{13}(\mathrm{pH} 10,0$ e Rstmp:AGU 0,03), do derivado (c) RA2 (pH 11,0 e Rstmp:AGU 0,03) e do (d) derivado $\mathrm{RA}_{15}$ (pH 10,0 e RSTMP:AGu 0,08), destacando a área da banda associada com o modo vibracional de $\delta_{\mathrm{s}}\left(-\mathrm{CH}_{3}\right)$ e de $\delta_{s}(\mathrm{O}-\mathrm{H})$

Figura 33 - Curvas de $\mu$ DSC com a linha de base corrigida do primeiro (a) e do segundo ensaio (b) do amido de mandioca nativo na razão mássica amido:água 1:3. 
Figura 34 - Curvas de $\mu \mathrm{DSC}$ com a linha de base corrigida do (a) derivado $\mathrm{R}_{1}(\mathrm{pH} 10,0$ e RSTMP:AGU 0,03) na razão mássica água:amido de 3,0 e do (b) derivado $R_{10}\left(\mathrm{pH} 11,0\right.$ e $R_{\text {StMP:AGu }} 0,03$ ) na razão mássica amido:água 1:3.

Figura 35 - Curvas de $\mu \mathrm{DSC}$ com a linha de base corrigida do primeiro (a) e do segundo ensaio (b) do derivado $\mathrm{R}_{11}$ (pH 10,0 e RSTMP:AGU 0,03) na razão mássica amido:água 1:3.

Figura 36 - Curvas de $\mu \mathrm{DSC}$ com a linha de base corrigida do primeiro ensaio do derivado $\mathrm{R}_{11}$ ( $\mathrm{pH}$ 10,0 e RstMP:AGu 0,03) deconvoluída no tempo (a) e do segundo ensaio de $R_{11}$ deconvoluída na temperatura (b) na razão mássica amido:água 1:3

Figura 37 - Curvas de $\mu \mathrm{DSC}$ com a linha de base corrigida do primeiro (a) e do segundo ensaio (b) do derivado $\mathrm{RA}_{1}$ (pH 10,0 e RSTMP:AGU $0,03)$ na razão mássica amido:água 1:3.

Figura 38 - Curvas de $\mu \mathrm{DSC}$ com a linha de base corrigida do primeiro (a) e do segundo ensaio (b) do derivado $\mathrm{RA}_{2}$ (pH 11,0 e RSTMP:AGU $0,03)$ na razão mássica amido:água 1:3.

Figura 39 - Curvas de $\mu \mathrm{DSC}$ com a linha de base corrigida do primeiro (a) e do segundo ensaio (b) do derivado $\mathrm{RA}_{11}(\mathrm{pH}$ 10,0 e RSTMP:AGU 0,08 ) na razão mássica amido:água 1:3.

Figura 40 - Curvas de $\mu \mathrm{DSC}$ com a linha de base corrigida do primeiro ensaio do derivado $\mathrm{RA}_{1}(\mathrm{pH} 10,0$ e RSTMP:AGU 0,03$)$ deconvoluída (a) no tempo e do segundo ensaio deconvoluída (b) na temperatura na razão mássica amido:água $1: 3$, e do primeiro ensaio do derivado $\mathrm{RA}_{14}(\mathrm{pH} 11,0$ e RSTMP:AGu 0,03 ) deconvoluída (c) no tempo e do segundo ensaio deconvoluída (d) na temperatura

Figura 41 - Espectro Raman normalizado das moléculas gelatinizadas e na forma granular do (a) derivado reticulado $R_{13}(\mathrm{pH} 10,0$ e

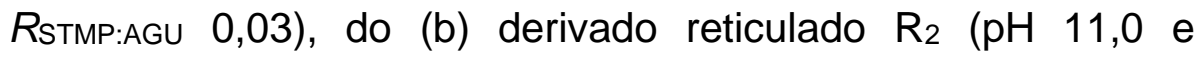
Rstmp:Agu 0,03), do (c) derivado reticulado $R_{15}(\mathrm{pH} 10,0$ e Rstmp:Agu 0,08) e do (d) derivado reticulado $\mathrm{R}_{16}(\mathrm{pH} 11,0$ e RSTMP:AGU 0,08)

Figura 42 - Relação entre os volumes gastos de $\mathrm{NaOH}(\mathrm{aq})$ a $3,0 \mathrm{~mol} \mathrm{~L}^{-1}$ para manter o meio de acetilação alcalino próximo de 10,0 do (a) 
sistema de reação sem amido de mandioca nativo e do (b) sistema de reação com amido de mandioca nativo.

Figura 43 - Curva de $\mu \mathrm{DSC}$ com a linha de base corrigida no resfriamento do (a) derivado $\mathrm{R}_{13}\left(\mathrm{pH} 10,0\right.$ e $R_{\text {StMP:AGu }} 0,03$ ), do (b) derivado $\mathrm{R}_{2}$ (pH 11,0 e RstMP:AGu 0,03), do (c) derivado $\mathrm{R}_{15}(\mathrm{pH} 10,0$ e

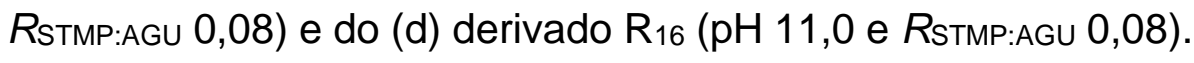

Figura 44 - Espectro Raman da (a) placa de Petri de poliestireno cristal na frequência de 3200 a $400 \mathrm{~cm}^{-1}$ adquirido nas condições em que os ensaios dos derivados acetilados foram realizados e o espectro Raman do (b) derivado RAs na frequência de 3200 a $400 \mathrm{~cm}^{-1}$ no qual as bandas do substrato predominaram. 


\section{LISTA DE TABELAS}

Tabela 1 - Composição do amido de mandioca nativo utilizado nos experimentos de reticulação e acetilação

Tabela 2 - Matriz do planejamento experimental $2^{2}$ fatorial com quatro réplicas $(N=4)$, identificando as condições do meio de reticulação dos experimentos de síntese do amido de mandioca reticulado

Tabela 3 - Comparação entre as condições do meio de acetilação e de processo da síntese do amido de mandioca acetilado do protocolo original e deste trabalho

Tabela 4 - Matriz completa dos experimentos de síntese dos derivados reticulados e acetilados de amido de mandioca

Tabela 5 - Programa de temperatura aplicado nos ensaios de microcalorimetria exploratória diferencial

Tabela 6 - Ordem randomizada de execução dos experimentos de síntese dos do amido de mandioca reticulado, com as respectivas condições de $\mathrm{pH}$, temperatura e razão molar de trimetafosfato trisódio (STMP) por unidade de anidroglicose (AGU) do meio de reticulação

Tabela 7 - Valores medidos de temperatura e pH (Média \pm Desvio Padrão) do meio de acetilação dos experimentos de síntese dos derivados acetilados de amido de mandioca

Tabela 8 - Valores médios dos parâmetros de gelatinização dos derivados reticulados de amido de mandioca separados por condição de reação nos experimentos de síntese dos derivados reticulados

Tabela 9 - Valores médios dos parâmetros de gelatinização dos derivados acetilados de amido de mandioca separados por condição de reação na reticulação

Tabela 10 - Valores (Média \pm Desvio Padrão) dos parâmetros de gelatinização dos derivados de amido de mandioca comparados com base nas condições de reação da reticulação e na acetilação dos derivados reticulados de amido de mandioca. 
Tabela 11 - Matriz final dos experimentos de síntese dos derivados reticulados de amido de mandioca, com os respectivos $\mathrm{pH}$ de reação e razão molar de trimetafosfato trisódio por unidade de anidroglicose 
AACC American Association of Cereal Chemists.

AAc Anidrido acético.

AGU Unidade de anidroglicose.

ANVISA Agência Nacional de Vigilância Sanitária.

ASTM American Society for Testing and Materials.

AOAC Association of Official Agricultural Chemists.

EMA European Medicines Agency.

FDA Food and Drug Administration.

ISO International Standard Organization.

L Transição de fase de cristal líquido.

M Transição do estado sólido para o líquido.

NA Amido de mandioca nativo.

STMP Trimetafosfato trisódio.

ua Unidade arbitrária.

HDSC Differential scanning microcalorimetry. 


\section{LISTA DE SÍMBOLOS}

$\Phi$

$\Delta \mathrm{m} \boldsymbol{H}$

$T_{m}$

$T_{m}^{0}$

$\mathbf{R}$

Vu

$\mathrm{V}_{1}$

$v_{1}$

$\chi_{1}$

$\mathbf{N}$

RSTMP:AGU

$\boldsymbol{R}_{\text {AAc:AGU }}$

ao

a1

22

$\boldsymbol{A}$

$\boldsymbol{\sigma}$

FWHM
Extremidade redutora das moléculas de amido (-).

Entalpia de gelatinização ou de fusão $\left(\mathrm{J} \mathrm{g}^{-1}\right)$.

Temperatura gelatinização ou de fusão na presença de diluente $\left({ }^{\circ} \mathrm{C}\right)$.

Temperatura de fusão do polímero puro $\left({ }^{\circ} \mathrm{C}\right)$.

Constante dos gases (arbitrária).

Volume molar por unidade polimérica (arbitrária).

Volume molar da água (arbitrária).

Fração volumétrica da água (-).

Parâmetro de interação entre a água e o polímero (-).

Tamanho de amostra (-).

Razão entre o número de mol de trimetafosfato trisódio e o número de mol de unidades de anidrogliose (-).

Razão entre o número de mol de anidrido acético e o número de mol de unidades de anidrogliose (-).

Altura da função gaussiana.

Centro da função gaussiana.

Meia largura à meia altura da função gaussiana.

Altura do pico de transição $(\mathrm{mW})$.

Desvio padrão da função gaussiana (-).

Largura à meia altura do pico da transição (s). 


\begin{tabular}{|c|c|}
\hline$T_{\mathrm{m}, \mathrm{i}}$ & $\begin{array}{l}\text { Temperatura inicial de gelatinização ou de fusão na presença de } \\
\text { diluente }\left({ }^{\circ} \mathrm{C}\right) \text {. }\end{array}$ \\
\hline$T_{\mathrm{m}, \mathrm{f}}$ & $\begin{array}{l}\text { Temperatura final de fusão ou de gelatinização na presença de } \\
\text { diluente }\left({ }^{\circ} \mathrm{C}\right) \text {. }\end{array}$ \\
\hline $\mathbf{u}$ & Modo vibracional de estiramento (-). \\
\hline Us & Modo vibracional de estiramento simétrico (-). \\
\hline Oas & Modo vibracional de estiramento assimétrico (-). \\
\hline$\delta$ & Modo vibracional de deformação (-). \\
\hline$\delta_{s}$ & Modo vibracional de deformação simétrica (-). \\
\hline$\delta_{\text {as }}$ & Modo vibracional de deformação assimétrica (-). \\
\hline$\delta_{\text {axial }}$ & Modo vibracional de deformação axial (-). \\
\hline$\eta_{1}$ & Índice de refração do elemento de reflectância interna (-). \\
\hline$\eta_{2}$ & Índice de refração da amostra (-). \\
\hline$D_{\mathrm{p}}$ & Profundidade de penetração da radiação infravermelha $(\mu \mathrm{m})$. \\
\hline $\boldsymbol{\theta}$ & $\begin{array}{l}\text { Ângulo de incidência da luz infravermelha na face interna do } \\
\text { elemento de reflectância }\left(^{\circ}\right) \text {. }\end{array}$ \\
\hline$\lambda$ & Comprimento de onda da luz infravermelha $(\mathrm{nm})$. \\
\hline $\boldsymbol{\mu}$ & Força iônica (mol L-1). \\
\hline$c_{i}$ & Concentração do íon i (mol L-1). \\
\hline $\mathbf{z}_{\mathbf{i}}$ & Carga ou número de oxidação do íon i (-). \\
\hline
\end{tabular}





\section{SUMÁRIO}

1 INTRODUÇÃO

2 OBJETIVO

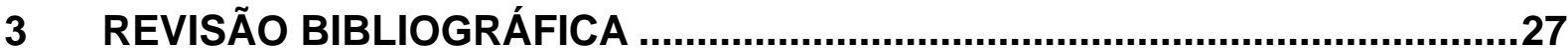

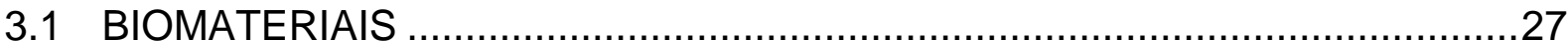

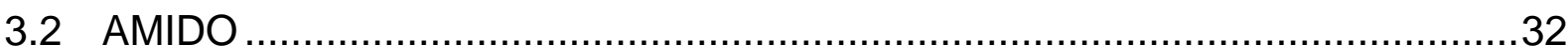

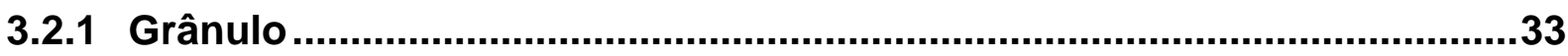

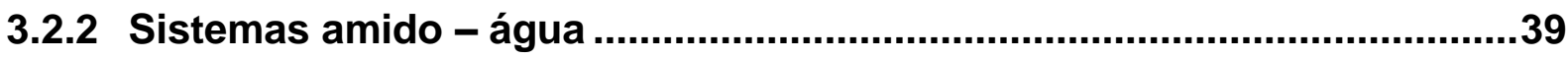

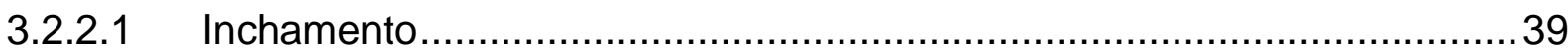

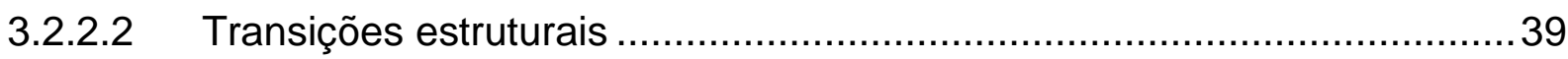

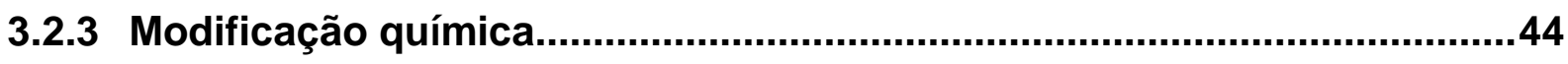

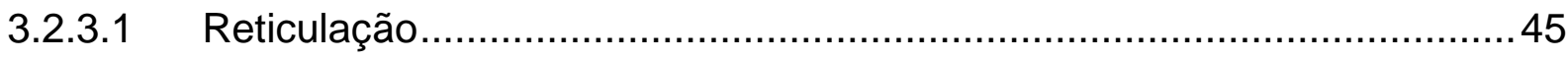

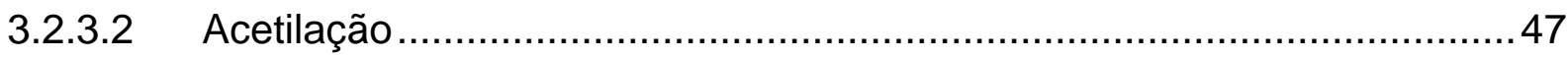

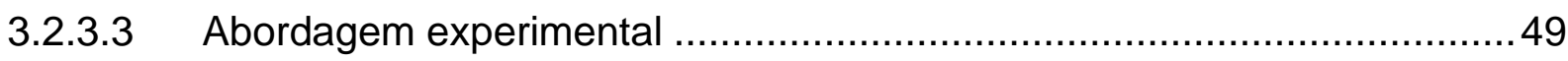

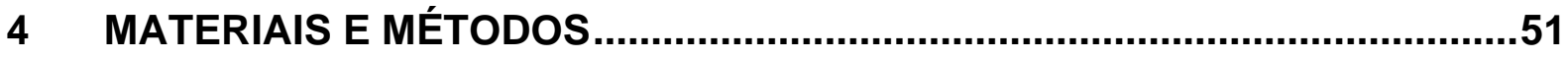

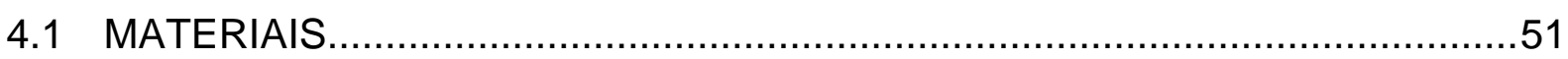

4.1.1 Síntese do amido de mandioca quimicamente modificado .....................51

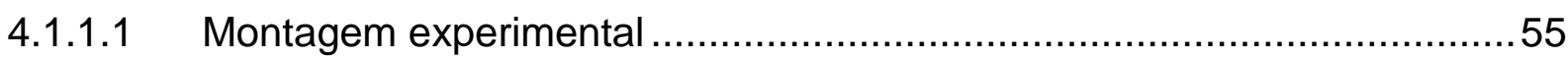

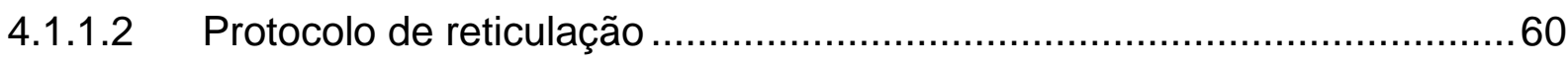

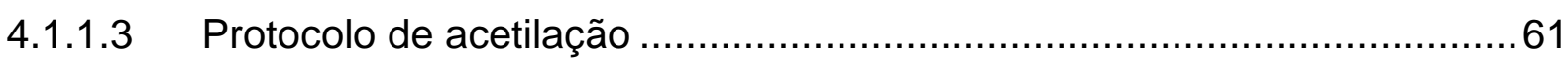

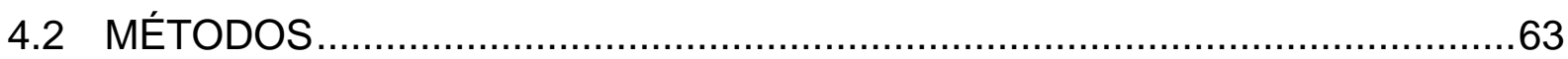

4.2.1 Parâmetros de gelatinização do amido de mandioca quimicamente modificado

4.2.2 Estrutura molecular do amido de mandioca quimicamente

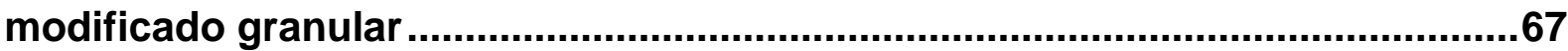

4.2.3 Estrutura molecular do amido de mandioca quimicamente modificado gelatinizado..............................................................................70

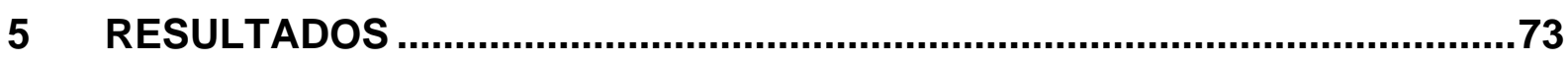

5.1 SÍNTESE DO AMIDO DE MANDIOCA QUIMICAMENTE MODIFICADO.........73 
5.2 ESTRUTURA MOLECULAR DO AMIDO DE MANDIOCA QUIMICAMENTE MODIFICADO GRANULAR.

5.3 PARÂMETROS DE GELATINIZAÇÃO DO AMIDO DE MANDIOCA QUIMICAMENTE MODIFICADO

5.4 ESTRUTURA MOLECULAR DO AMIDO DE MANDIOCA QUIMICAMENTE MODIFICADO GELATINIZADO

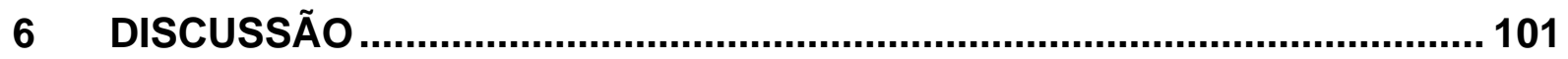

6.1 SÍNTESE DO AMIDO DE MANDIOCA QUIMICAMENTE MODIFICADO ...... 101

6.2 ESTRUTURA MOLECULAR DO AMIDO DE MANDIOCA QUIMICAMENTE MODIFICADO GRANULAR

6.3 PARÂMETROS DE GELATINIZAÇÃO DO AMIDO DE MANDIOCA QUIMICAMENTE MODIFICADO

6.4 ESTRUTURA MOLECULAR DO AMIDO DE MANDIOCA QUIMICAMENTE

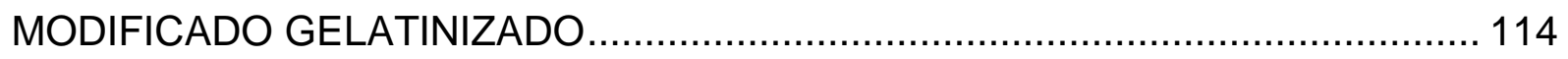

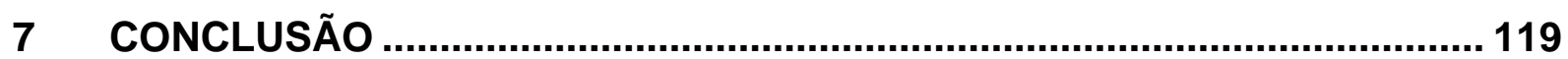

SUGESTÕES PARA TRABALHOS FUTUROS................................................ 121

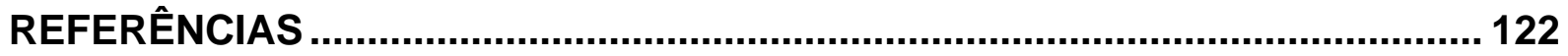




\section{INTRODUÇÃO}

Os polissacarídeos compreendem uma classe de materiais com propriedades químicas que se situam entre as propriedades dos polímeros sintéticos e as dos biopolímeros com funções biológicas no corpo humano, e a modificação química das moléculas dos polissacarídeos permite o controle sobre essas propriedades para fabricar biomateriais (TIBBITT; LANGER, 2017; WILSON, 2019).

Polissacarídeos quimicamente modificados são empregados em diferentes áreas da medicina. Como exemplos, podem ser mencionados os géis de ácido algínico usados para regenerar pele e ossos; as nanopartículas de quitosana usadas para transportar e liberar insulina no intestino; e as soluções de hidroxietilamido usadas para manter o volume do sangue em pacientes de unidades de terapia intensiva (KWON; LO; BHATIA, 2016; MARIJNISSEN et al., 2002; STEVENS et al., 2005; ZARYCHANSKI et al., 2013).

O hidroxietilamido é um amido de milho quimicamente modificado capaz de expandir na corrente sanguínea sem causar resposta adversa do sistema imunológico. Por essas características, este amido modificado tem o potencial para transportar moléculas-fármaco pela corrente sanguínea até às células doentes nos tratamentos de câncer (SLEIGHTHOLM et al., 2017; ZHAO et al., 2017).

Entretanto, os artigos de Myburgh et al. (2012 e 2016) e o de Zarychanski et al. (2013) mostraram que a eficácia e a segurança do hidroxietilamido como expansor de volume de plasma sanguíneo foram mal avaliadas por estudos tendenciosos. Como consequência disso, as principais agências de saúde alertaram sobre os riscos à saúde pública associados com o uso do hidroxietilamido (ANVISA, 2013a; ANVISA, 2013b; EMA, 2013a; EMA, 2013b; EMA, 2018; FDA, 2013).

Esses artigos também inspiraram este trabalho: a complexidade da interação organismo-biomaterial e a necessidade de desenvolvimento de um trabalho com metodologia precisa e confiável são desafios nos estudos sobre biomateriais. Em outras palavras, mesmo sem mencionarem qual seria a causa dos problemas com o hidroxietilamido nos artigos supracitados, foi possível deduzir que as condições do meio como variações de $\mathrm{pH}$, atividade de proteínas e a presença de íons influenciam o comportamento das moléculas de hidroxietilamido e a sua interação com os componentes do sangue. 
As moléculas do amido se organizam em grânulos que incham na presença de água e de íons e, durante o processo de modificação, a estrutura do grânulo deve ser preservada para o produto ser utilizado como medicamento (FDA, 2017).

A acetilação e a reticulação são os processos de modificação química do amido mais estudados (SINGH; KAUR; MCCARTHY, 2007). Apesar disso, poucos estudos na literatura específica se preocuparam com a integridade do grânulo na modificação, por meio do monitoramento e do controle das condições do meio de reação, e com a eficácia do processo de modificação das moléculas do amido (AGUIAR, 2014; JETTEN; STAMHUIS; OOSTEN,1980; PHILLIPS et al., 1999).

Aguiar (2014) sintetizou amido reticulado a partir do amido de mandioca nativo e do trimetafosfato trisódio para utilizar o derivado como matéria-prima na fabricação de plástico biodegradável, o qual foi testado como suporte em um sistema de liberação controlada de óxido nítrico, para uma aplicação biomédica. Contudo, os resultados para comprovar a reticulação das moléculas do amido de mandioca foram inconclusivos.

Por isso, este trabalho propôs uma abordagem experimental diferente na qual o amido de mandioca nativo foi reticulado e, posteriormente, acetilado em uma unidade de síntese química automatizada construída em laboratório capaz de monitorar a temperatura e o pH, com controle do $\mathrm{pH}$ do meio de reação.

Neste contexto, o objetivo deste trabalho foi sintetizar amido de mandioca reticulado e acetilado em condições de reação monitoradas com o propósito de avaliar se as condições do meio reacional causam alteração física ou química no grânulo que comprometa a sua estrutura e, consequentemente, a eficácia do processo de modificação química. 


\section{OBJETIVO}

Sintetizar amido de mandioca reticulado e acetilado sob condições de reação monitoradas e com controle de $\mathrm{pH}$. Verificar a relação entre as condições do meio de reação e a estabilidade do grânulo com o propósito de avaliar potenciais aplicações dos produtos na área biomédica.

Para tanto, as etapas deste trabalho foram:

- Montar uma unidade de síntese química automatizada para conduzir os experimentos de modificação química do amido de mandioca;

- Reticular o amido de mandioca nativo com trimetafosfato trisódio variando $\circ \mathrm{pH}$ e a razão molar trimetafosfato trisódio por unidade de anidroglicose, mantidos constantes a temperatura e o tempo de reação;

- Acetilar o amido de mandioca reticulado com anidrido acético, mantendo nas mesmas condições de $\mathrm{pH}$, razão molar anidrido acético por unidade de anidroglicose, temperatura e tempo de reação;

- Caracterizar os derivados de amido de mandioca por meio da microcalorimetria exploratória diferencial, da espectroscopia de absorção no infravermelho e da microscopia Raman. 


\section{REVISÃO BIBLIOGRÁFICA}

\subsection{BIOMATERIAIS}

Biomateriais são materiais utilizados pela medicina para diagnosticar e tratar doenças, e para substituir partes de sistemas do corpo humano sem provocar resposta imune que comprometa a eficácia do procedimento médico e a saúde do paciente (RATNER, 2015; WILLIAMS, 2008).

Os biomateriais são feitos de metais, de cerâmicas, de plásticos ou de composições de mais de um material. Como exemplos, podem ser citados nanopartículas de óxido de ferro para diagnosticar câncer por imagem, nanocarreadores de fármacos de poli (óxido de etileno) para tratar tumores e estruturas de aço inoxidável e poli (metil metacrilato) para substituir ossos (ANDERSON; BURDICK; LANGER, 2004; CHENG et al., 2015; HARISINGHANI et al., 2003; PEER et al., 2007).

A presença do biomaterial sempre desencadeará uma resposta imunológica (TIBBITT; LANGER, 2017). Isto é um desafio para a medicina que enfrenta problemas como a rejeição e o depósito excessivo de proteínas sobre os implantes, os quais, por sua vez se traduzem nas principais causas de fracasso de testes clínicos (LANGER; TIRREL, 2004; TIBBITT; LANGER, 2017).

Desse modo, é importante que os biomateriais sejam desenvolvidos de forma a garantir a segurança e a melhor resposta do corpo. A biocompatibilidade é a propriedade chave dos biomateriais que garante a efetividade desse processo (WILLIAMS, 2008).

Esperava-se dos primeiros biomateriais-juntas ósseas de metal e poli (metacrilato de metila) e lentes de contato de vidro-que fossem inertes no corpo humano e não quebrassem, a preocupação era com a resistência mecânica (CHARNLEY, 1960; COPELAND et al., 2012; TIBBIT; LANGER, 2017).

Nos últimos anos, a busca é por materiais bioativos que interajam com as células e os sistemas do corpo e sejam capazes de interpretar sinais químicos e elétricos para induzir respostas biológicas que ajudem o próprio corpo humano a restabelecer a saúde e a promover a sua reparação (KWON; LO; BHATIA, 2016; TIBBIT; LANGER, 2017). 
Os ossos possuem a capacidade de regeneração, que diminui ao longo da vida, e pode ser estimulada por alguns materiais cerâmicos e vítreos. Por exemplo, reações químicas ocorrem na superfície de vidros bioativos quando estes estão em contato com os ossos, formando a hidroxi-carbonato-apatita. Esta última, ao interagir com as células, impulsiona uma sequência de reações bioquímicas responsáveis pelo crescimento de células específicas que direcionam o sistema esquelético à autorreparação (ALSBERG et al., 2002; WINKLER et al., 2018).

Áreas pequenas costumam responder melhor a tratamentos que as áreas grandes, pois a interface biomaterial-células é menor sem a presença de componentes do sangue. Nem todo biomaterial é compatível com o sangue, a incompatibilidade se revela quando o sistema imune não reconhece o material e tenta isolar ou destruí-lo (SHAH et al., 2014; WILLIAMS, 2008).

O enxerto ósseo é o procedimento mais usado para reparar áreas grandes. Nesse caso, a área danificada é reconstruída usando um pedaço de osso removido do quadril do próprio paciente, que é caracterizado como um procedimento sem risco de rejeição. As desvantagens o tornam inadequado para crianças, nas quais 0 tamanho do osso retirado do quadril é limitado, o procedimento é agressivo e a recuperação é dolorosa (SHAH; JUNG; SKIRBOLL, 2014; TOLLEMAR et al., 2016).

A engenharia de tecidos propõe uma abordagem alternativa que consiste em abrir buracos em regiões dos ossos onde as células não-diferenciadas são abundantes e preencher essas cavidades com hidrogéis, contendo substâncias que estimulam a diferenciação e o crescimento celular. Os testes em animais usaram hidrogéis de polissacarídeos para mostrar a eficácia da técnica que, atualmente, é a alternativa para reparar crânios de crianças (PEK et al., 2008; STEVENS et al., 2005; TOLLEMAR et al., 2016; WINKLER et al., 2018).

Hidrogéis à base de ácido algínico ou de ácido hialurônico são os utilizados como suporte para células na engenharia de tecidos, nanopartículas de quitosana são utilizadas como transportadoras de insulina para o intestino em sistemas de liberação controlada de fármacos, e medicamentos à base de amido são utilizados em tratamentos médicos intensivos (MARIJNISSEN et al., 2002; MCCULLENS; CHOW; STEVENS, 2011; MIZRAHY; PEER, 2012; MOSER, 1986;

O uso dos polissacarídeos como biomateriais não é direto; as macromoléculas precisam ser quimicamente modificadas para serem testadas como biomateriais. Os grupos funcionais existentes nas unidades básicas de cada molécula são substituídos 
por outros grupos funcionais para aumentar a resistência mecânica dos hidrogéis, tornar as moléculas menos sujeitas ao ataque de proteínas presentes no sangue ou torná-las moléculas ativas no tratamento de doenças (HEINZE; LIEBERT; KOSCHELLA, 2003; SLEIGHTHOLM et al., 2017).

O grau de inchamento e a resistência mecânica dos hidrogéis podem ser controlados por meio da reticulação das macromoléculas. Ao reagir o polissacarídeo com trimetafosfato trisódio (STMP), grupos fosfato são introduzidos nas moléculas e podem servir de ponte entre elas, unindo-as por meio de ligações covalentes. Várias pontes formam uma rede que impede as moléculas de se deformarem e incharem, conferindo maior resistência mecânica aos hidrogéis (FLORY, 1953; STEVENS et al., 2005).

A susceptibilidade das macromoléculas de amido ao ataque das proteínas do sangue diminui por meio da hidroxietilação ou da acetilação. A presença dos grupos funcionais como o hidroxietila $\left(-\mathrm{CH}_{2}-\mathrm{CH}_{2}-\mathrm{OH}\right)$ ou o acetila $\left(\mathrm{CH}_{3} \mathrm{CO}-\right)$ inibe 0 ataque da $\alpha$-amilase que não consegue se acoplar às moléculas por não reconhecer o grupo funcional (MOSER, 1986; TREIB et al., 1996).

A atividade biológica das macromoléculas é também potencializada por meio da substituição dos grupos funcionais por moléculas inativas de fármacos. Nesse caso, a macromolécula do polissacarídeo é o veiculo de transporte do fármaco pela corrente sanguínea até ao local onde estão as células doentes. Nesse local, alterações fisiológicas como expressão enzimática aumentada, variação na concentração de íons ou mudança de $\mathrm{pH}$ causadas pelas células doentes irão facilitar a liberação do fármaco (KWON; LO; BHATIA, 2016; SLEIGHTHOLM et al., 2017; ZHAO et al., 2017).

O hidroxietilamido é um biomaterial de amido constituído por macromoléculas de amilopectina que são hidrolisadas com ácido para padronizar a massa molecular antes de serem modificadas. Depois de hidrolisadas, grupos hidroxietila $\left(-\mathrm{CH}_{2}-\mathrm{H}_{2}-\right.$ $\mathrm{OH})$ são inseridos nas moléculas, reagindo o amido com o óxido de eteno $\left(\mathrm{C}_{2} \mathrm{H}_{4} \mathrm{O}\right)$ em meio alcalino, como mostrado na Figura 1, cujo derivado pode ser manufaturado como expansor de plasma do sangue. 
Figura 1 - Modificação química do amido para a síntese do hidroxietilamido utilizado como expansor de plasma do sangue.

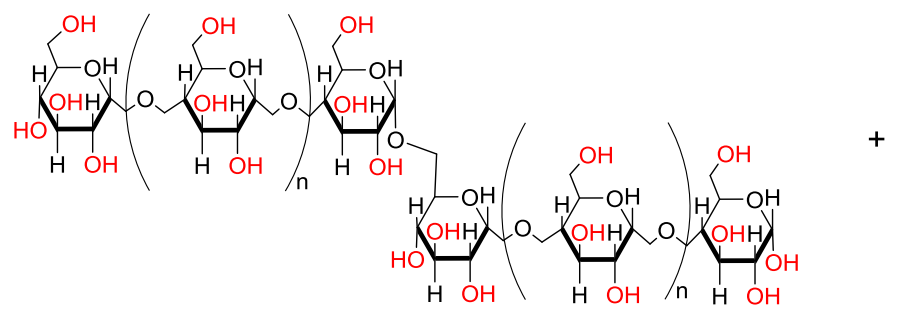

Amilopectina
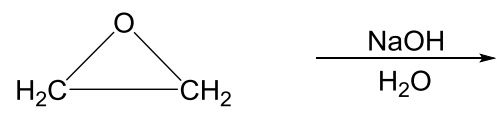

Óxido de eteno

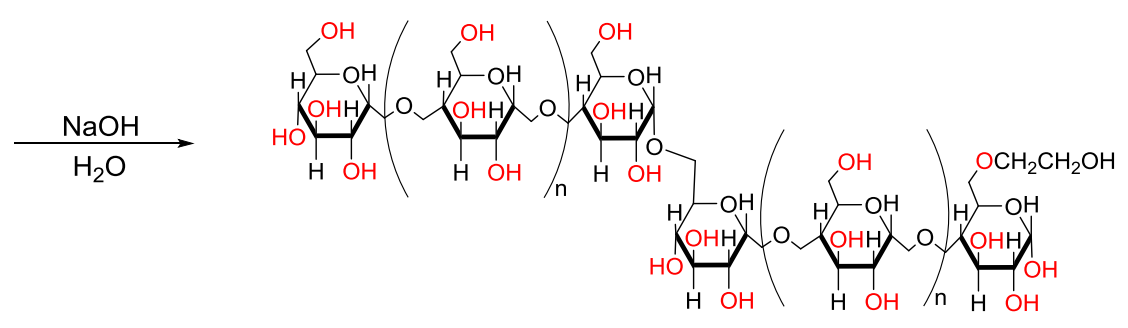

Hidroxietilamido

A quantidade dos novos grupos funcionais determina o tempo de vida do hidroxietilamido na corrente sanguínea (MOSER, 1986; TREIB et al., 1996). Qualquer grupo hidroxila $(-\mathrm{OH})$ nos carbonos 2, 3 e 6 na unidade de anidroglicose pode ser substituído por grupos hidroxietila e a razão molar de substituição (número de mols de hidroxietila ligado ao amido por unidade de anidroglicose) é o parâmetro que informa a quantidade de posições substituídas por unidade de anidroglicose. Este parâmetro, a relação entre as quantidades de grupos hidroxietila de cada posição e a massa molecular média das moléculas de amilopectina são as informações que os profissionais de saúde usam para decidir em quais situações usar esse expansor de plasma (MYBURGH et al., 2012; ZARYCHANSKI et al., 2013).

Essas informações também são levadas em consideração para decidir qual hidroxietilamido é o mais indicado para sofrer nova modificação e ser empregado como droga polimérica. Um exemplo é a modificação química do hidroxietilamido com razão molar de substituição de 0,5 por fármacos usados para tratar câncer de pâncreas e próstata (SLEIGHTHOLM et al., 2017; ZHAO et al., 2017).

Soluções à base de hidroxietilamido foram apresentadas à comunidade médica como potencial substitutos de plasma sanguíneo na década de 1960. Mais tarde, as 
agências regulatórias de saúde de diferentes partes do mundo aprovaram tais soluções como medicamento seguro e eficaz para manter o volume sanguíneo em casos de choque hemorrágico, trauma e infeção do sangue em pacientes de unidades de terapia intensiva, fazendo do hidroxietilamido o expansor coloidal de plasma mais utilizado no mundo (HARTOG; KOHL; REINHART, 2011; IRIKURA et al., 1976; KNORPP et al., 1967; MOSER, 1986; MYBURGH et al., 2012; TREIB et al., 1996).

Entretanto, registros na literatura mencionam que o uso prolongado do expansor pode mudar o comportamento reológico do sangue, causar problema de coagulação ou acumular nos órgãos do sistema circulatório (HARTOG; KOHL; REINHART, 2011; TREIB et al., 1996). Testes clínicos com pacientes de unidades de terapia intensiva mostraram que o expansor coloidal de hidroxietilamido está associado com o aumento do risco de morte e problemas renais (HARTOG; KOHL; REINHART, 2011; KUPFERSCHMIDT, 2012a; KUPFERSCHMIDT, 2012b; MYBURGH et al., 2012; MYBURGH et al., 2016; ZARYCHANSKI et al., 2013).

O maior dos testes comparou o estado de saúde de 7000 pacientes adultos de unidades de terapia intensiva durante 90 dias para avaliar a eficácia e a segurança do hidroxietilamido como expansor de plasma do sangue. Os pacientes foram divididos em dois grupos, solução a $6 \mathrm{mg} / 100 \mathrm{~mL}$ de hidroxietilamido-massa molecular média de $1,3 \times 10^{5} \mathrm{~kg} \mathrm{kmol}^{-1}$ e razão molar de substituição igual a $0,4 \mathrm{em} \mathrm{NaCl} \mathrm{a} 0,9 \mathrm{mg} / 100$ $\mathrm{mL}$-foi dada para um grupo enquanto soro—solução de $\mathrm{NaCl}$ a $0,9 \mathrm{mg} / 100 \mathrm{~mL}$-foi dado ao grupo de controle. Os resultados mostraram que o uso da solução de hidroxietilamido está associado com mais efeitos colaterais como a falência dos rins $(4,6 \%$ versus $3,3 \%, p=0,006)$ e não está associado com menor número de mortes (MYBURGH et al., 2012; MYBURGH et al., 2016).

Zarychanski et al. (2013) selecionaram 38 testes clínicos nos quais o hidroxietilamido-a 6 ou $10 \mathrm{mg} / 100 \mathrm{~mL}$ em solução salina, massa molecular variando de 1,2 a $4,5 \times 10^{5} \mathrm{~kg} \mathrm{kmol}^{-1}$ e a razão molar de substituição de 0,4 a 0,7 -foi comparado com soluções salinas de $\mathrm{NaCl}$ ou Ringer e com soluções coloidais de albumina e gelatina, envolvendo 10290 pacientes adultos. Os pesquisadores mostraram que o hidroxietilamido está associado com o aumento do risco de morte de pacientes muito debilitados (risco relativo: 1,09; intervalo de confiança $95 \%, 1,02$ a 1,17 ; risco absoluto: $1,51 \%$, intervalo de confiança $95 \%, 0,02 \%$ a $3,00 \%$ ) e 
desaconselharam o uso do medicamento como expansor de plasma do sangue nesses pacientes.

A partir disto, ações foram tomadas. No Brasil, a AGÊNCIA NACIONAL DE VIGILÂNCIA SANITÁRIA (ANVISA, 2013) emitiu um alerta do sistema nacional de saúde proibindo o uso de soluções de hidroxietilamido em pacientes com maior risco de sangramento e de doenças renais. Já a agência americana FOOD AND DRUG ADMINISTRATION (FDA, 2013) proibiu o uso do medicamento em pacientes muito doentes com infecção no sangue e de unidades de terapia intensiva, enquanto que e a agência européia EUROPEAN MEDICINES AGENCY (EMA, 2013) proibiu o uso em pacientes com infecção no sangue, queimaduras graves e debilitados com risco de vida ou problemas renais e solicitou a retirada do medicamento do mercado (ANVISA, 2013a; ANVISA, 2013b; EMA, 2013a; EMA, 2013b; EMA, 2018; FDA, 2013).

O potencial de ameaça do hidroxietilamido à saúde pública é proporcional ao desconhecimento de como as moléculas de amido crescem e se cristalizam na forma de grânulo, caracterizado como uma estrutura insolúvel em água, mas que se dissolve à medida que moléculas de água se difundem para o interior do grânulo por meio do aumento da temperatura ou da interação com íons (BILIADERIS, 2009; CALVERT; 1997).

\subsection{AMIDO}

O amido é um biopolímero de glicose formado de duas macromoléculas a amilopectina e a amilose, que são a reserva de energia dos vegetais superiores. Elas são sintetizadas no interior de organelas celulares denominadas amiloplastos, e à medida que crescem ganham a forma única de uma estrutura semicristalina e mais densa que a água chamada grânulo (JANE, 2009; JARVIS; LÓPEZ-JUEZ; 2013).

A amilopectina é o componente de maior quantidade pode chegar a $80 \mathrm{~g} / 100 \mathrm{~g}$ da composição total do amido nativo. As ligações glicosídicas $\alpha-D-(1 \rightarrow 4)$ e $\alpha$-D-(1 $\rightarrow$ 6) unem as unidades de anidroglicose. Os locais em que ocorrem as ligações $\alpha$-D-(1 $\rightarrow 6$ ) são os pontos de ramificação das moléculas de amilopectina, como visualiza-se na Figura 2 (JANE, 2009; PÉREZ, BERTOFT; 2010). 
Figura 2 - Estrutura molecular da (a) amilopectina, com destaque para um ponto de ramificação, e do seu dissacarídeo básico a isomaltose. Estrutura molecular da (b) amilose, mostrando sua estrutura linear e do seu dissacarídeo básico a maltose.

(a)

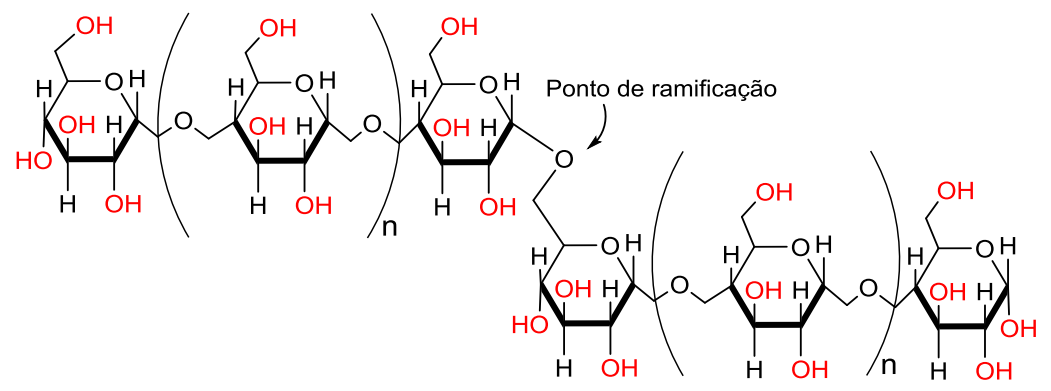

Amilopectina

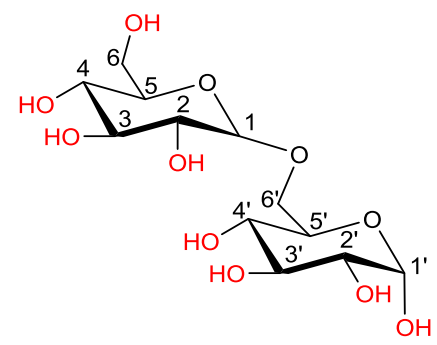

Isomaltose

(b)

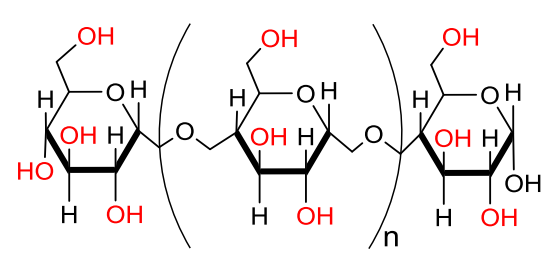

Amilose

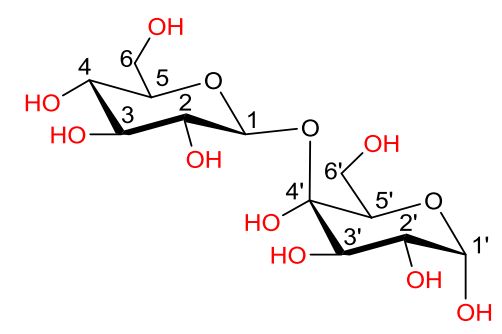

Maltose

A amilose compõe geralmente até $30 \mathrm{~g} / 100 \mathrm{~g}$ do amido nativo, suas unidades de anidroglicose estão unidas principalmente por ligações $\alpha-D-(1 \rightarrow 4)$ e com poucos pontos de ramificação, como mostrado na Figura 2 (JANE, 2009).

Entre amilopectina e a amilose, água, lipídios, proteínas, e mono-ésteres de fosfato são os outros componentes do grânulo (BILIADERIS, 2009; JANE, 2009; PÉREZ; BALDWIN; GALLANT, 2009). O grânulo é uma estrutura multicomponente em que as moléculas de amilopectina revelam suas principais propriedades físicas. (BILIADERIS, 2009; JANE, 2009; ZOBEL, 1988).

\subsubsection{Grânulo}

A amilopectina é uma das maiores macromoléculas naturais. Elas são assimétricas e crescem lado a lado com tal organização que partes das moléculas formam regiões cristalinas dispersas na porção amorfa do grânulo (JANE, 2009; 
OOSTERGETEL; VAN BRUGGEN, 1993; PÉREZ; BALDWIN; GALLANT, 2009). Por isso, o amido é um material birrefringente, como visto na micrografia da Figura 3, e a medida dessa propriedade indica a presença de cristais de amilopectina (BILIADERIS, 2009; GHIASI; HOSENEY; VARRIANO-MARSTON, 1982).

Figura 3 - Grânulos de amido vistos em um microscópio de luz polarizada, mostrando os padrões de interferência cruzada. Magnificação 250x

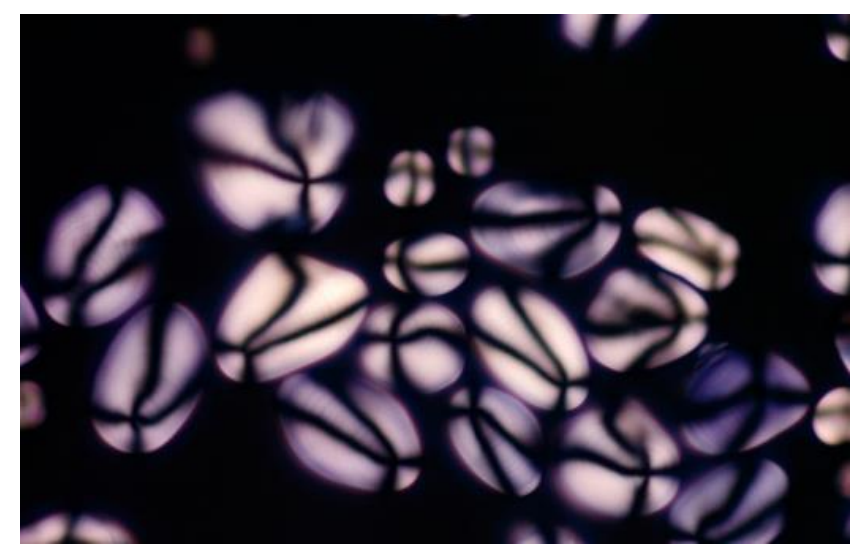

Fonte: Getty Images (DeAgostini), 2003.

A estrutura ramificada da amilopectina é formada por três tipos de cadeias: A, $B$ e $C$. As cadeias $A$ se ligam por uma das extremidades redutoras às cadeias $B$ ou $C$ e não ligam entre si, as cadeias $B$ se ligam a $A$ ou a $C$ no carbono 6 da unidade de anidroglicose ( $A G U$ ) e há apenas uma cadeia $C$ que carrega a extremidade redutora (Ф) da molécula (HIZUKURI, 1985; JANE, 2009).

As cadeias $A$ e $B$ têm comprimentos que variam em faixas características. As cadeias A podem ter o comprimento equivalente de 6 a 12 unidades de anidroglicose enquanto os comprimentos das cadeias $B$ variam em faixas maiores. Tais faixas acima de 12 unidades são assim divididas: cadeias com 13 a 24 unidades de anidroglicose correspondem a B1; com 25 a 36 unidades de anidroglicose correspondem a B2; e com 37 ou mais unidades de anidroglicose a B3 (Figura 4) (HIZUKURI, 1986; JANE, 2009). 
Figura 4 - Esquema de uma molécula de amilopectina mostrando as ramificações das cadeias que originam as regiões cristalinas.

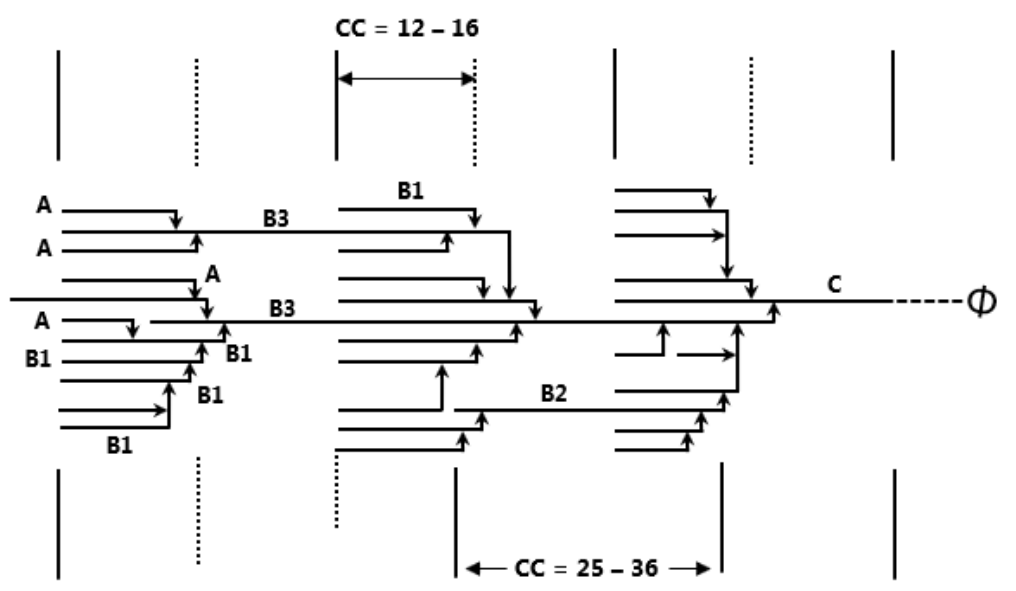

Fonte: Adaptado de Hizukuri (1986)

CC é o comprimento de cadeia em número de unidades de anidroglicose.

Essas cadeias se entrelaçam com giro para a esquerda e formam as hélices duplas. Tais hélices conferem rigidez às moléculas de amilopectina e isso auxilia as hélices a se emparelharem, dando assim origem aos cristais (BERTOFT, 2004; BERTOFT et al., 2016; HIZUKURI; KANEKO; TAKEDA, 1983; PÉREZ; BALDWIN; GALLANT, 2009). Os cristais, por sua vez, se agrupam em regiões cristalinas chamadas de clusters, as quais podem se organizar em dois arranjos: o monoclínico ou o hexagonal (PÉREZ; BALDWIN; GALLANT, 2009).

As hélices duplas estão compactadas de tal modo que não há espaço vazio no arranjo monoclínico. Elas estão unidas por ligações de hidrogênio de forma direta uma a outra e indiretamente por meio de quatro moléculas de água alocadas no interior de cada célula unitária do cristal.

No arranjo hexagonal, seis hélices duplas formam um hexágono no qual 18 moléculas de água formam ligações de hidrogênio que mantêm as hélices unidas. No espaço central da célula unitária, mais 18 moléculas de água formam uma estrutura em rede, organizada com número de coordenação próximo de quatro (BRUBACH, 2005; LECHERT, 1981; PÉREZ; BALDWIN; GALLANT, 2009; WARREN et al., 2013).

As moléculas de amilopectina avançam mergulhadas na porção amorfa sem uma delimitação firme entre o que é essencialmente amorfo ou cristalino, como mostrado na Figura 5. O modelo building block backbone de organização da 
amilopectina prevê que uma rede de cadeias lineares, localizada na porção amorfa da camada de crescimento, determina a organização da região cristalina (BERTOFT et al., 2010; BERTOFT, 2013; PÈREZ; BERTOFT, 2010).

Figura 5 - Camada de crescimento das moléculas de amilopectina no amido de mandioca de acordo com o modelo backbone de organização.

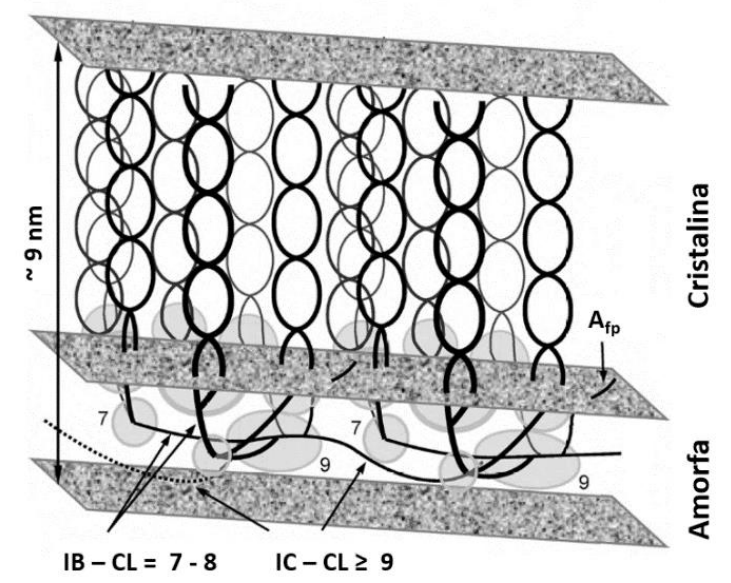

Fonte: BERTOFT et al. (2010).

$A_{f p}$ é a menor cadeia backbone ramificada que pode avançar para regiões cristalinas.

IB - CL é a cadeia backbone de 7 a 8 unidades de anidroglicose, interligando blocos de hélices duplas.

IC - CL é a cadeia backbone de 9 ou mais unidades de anidroglicose, interligando clusters.

Cada cadeia linear tem um comprimento específico para cada tipo de amido e cada uma une hélices duplas de pares de arranjos cristalinos também específicos (BERTOFT et al., 2010; BERTOFT, 2013; GOREN, 2017).

As moléculas de amilopectina param pouco a pouco de crescer por conflito estérico nas regiões de maior cristalinidade, esparsando cristais no domínio amorfo e assim o grânulo ganha forma sobrepondo camadas-como uma cebola—de 300 a $400 \mathrm{~nm}$ de espessura, alternando entre regiões cristalinas e amorfas, como visualizase no esquema da Figura 6 (BERTOFT et al., .2010; BERTOFT, 2013; BILIADERIS, 2009; GOREN, 2017). 
Figura 6 - Esquema de comparação das características estruturais das macromoléculas de amido.

\section{Amilopectina}

Amilose

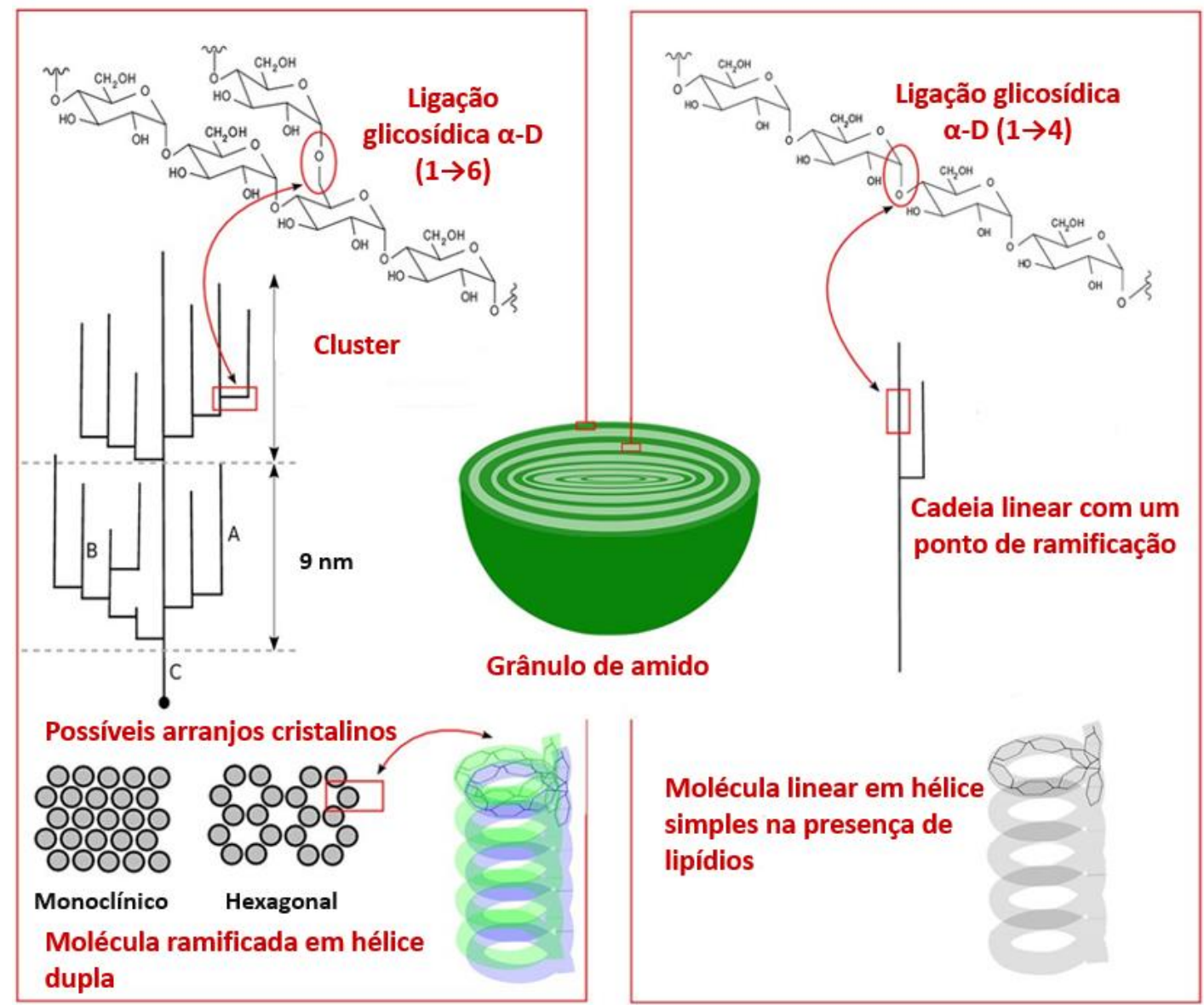

Fonte: Adaptado de Raguin, Ebenhoh (2017).

Se as hélices se organizarão em arranjo monoclínico ou hexagonal, isso dependerá da temperatura e da quantidade de água. Como essas condições podem variar durante a polimerização e a cristalização das moléculas do amido, os dois arranjos podem coexistir em um mesmo grânulo (JANE 2009; PÉREZ; BALDWIN; GALLANT, 2009).

O formato final do grânulo pode ser esférico, oval, elipsoidal ou discóide de dimensões características que variam de 0,1 a $100 \mu \mathrm{m}$. O diâmetro dos grânulos de um mesmo amido pode assumir valores que vão de 4 a $40 \mu \mathrm{m}$, como é o caso do amido de mandioca (VAMADEVAN; BERTOFT; 2015 ). Essa variabilidade de tamanho do grânulo deve ser considerada ao avaliar suas propriedades físicas (JANE 2009; PÉREZ; BALDWIN; GALLANT, 2009). 
As moléculas de amilose estão isoladas e dispersas nas regiões amorfas entre as moléculas de amilopectina. A literatura sugere que essas moléculas estão entrelaçadas com as de amilopectina o que mantém o grânulo coeso (BILIADERIS, 2009).

As cadeias dos poucos pontos de ramificação assumem a forma de dupla hélice, mesmo assim não cristalizam à medida que crescem. No entanto, se estiverem próximas de moléculas de lipídios, as moléculas de amilose se enrolam, formando os complexos amilose-lipídio, como esquematizado na Figura 6. Estes se forem impedidos de se movimentar por interação energética ou por efeito estérico, se organizam como cristais (BILIADERIS; GALLOWAY, 1989; GIDLEY; BOCIEK 1988; GODET et al., 1996; JANE, 2009; JANE; ROBYT, 1984; ZOBEL, 1988)

A região amorfa representa a maior parte do grânulo, região esta onde as moléculas de água se difundem. Quanto maior for a movimentação das moléculas de água, maior a susceptibilidade dos cristais de amilopectina e de complexos de amilose-lipídio fundirem por causa do efeito diluente da água no processo de fusão (BILIADERIS, 2009; FLORY, 1953; WARREN et al., 2013). 


\subsubsection{Sistemas amido - água}

A interação entre as moléculas de amido com as moléculas de água causa mudanças estruturais que levam à ruptura do grânulo e à dissolução das moléculas de amilopectina e amilose (JANE, 2009; BILIADERIS, 2009).

O inchamento, a fusão dos cristais de amilopectina e a fusão dos cristais de amilose-lipídio são os eventos mais monitorados quando se estuda formas de controlar a ruptura do grânulo (Al; JANE, 2015; BILIADERIS, 2009; WANG et al., 2016).

\subsubsection{Inchamento}

O inchamento do grânulo ocorre quando as moléculas de amilopectina absorvem certa quantidade de água e se deformam sem romper a estrutura do grânulo (BILIADERIS, 2009; MOSER, 1986).

Para as moléculas de amilopectina se deformarem, além da presença da água, é necessário o aumento da temperatura, provocando a mobilidade da água e facilitando sua própria difusão até as regiões cristalinas do grânulo (LECHERT, 1981). As moléculas de amilose também absorvem água e se deformam, projetando-se para fora do grânulo a depender do grau de inchamento alcançado (BILIADERIS, 2009).

A deformação das moléculas de amido é a primeira mudança estrutural do fenômeno de gelatinização cujo evento principal é a fusão dos cristais de amilopectina (BILIADERIS, 2009).

\subsubsection{Transições estruturais}

Transições estruturais das moléculas de amilopectina e de amilose devido ao aumento de temperatura ou ao efeito de interações íons-água-amilopectina-amilose causam a gelatinização do amido (AI; JANE, 2015; BILIADERIS, 2009; GOUGH; PHYBUS, 1973; JANE, 1993; OOSTEN, 1982; OOSTEN, 1990).

A gelatinização macroscopicamente se revela pelo aumento da viscosidade quando uma suspensão aquosa de amido é aquecida até a temperatura de $90{ }^{\circ} \mathrm{C}$, ou quando solução de $\mathrm{NaOH}$ é adicionada à suspensão em temperatura ambiente. Em 
ambos casos, o grânulo rompe e os seus componentes se dispersam na água (GOUGH; PHYBUS, 1973; OOSTEN, 1982; OOSTEN, 1990; RANDZIO et al., 2002; VAMADEVAN et al., 2013).

O aumento da temperatura causa a mobilidade da água no interior do grânulo, as moléculas de amilopectina absorvem a água, se deformam e o volume do grânulo aumenta (BILIADERIS, 2009; LECHERT, 1981; PÉREZ; BALDWIN; GALLANT, 2009). Em seguida, as ligações de hidrogênio das hélices duplas dos cristais se desestabilizam e os cristais se soltam da rede cristalina (BILIADERIS, 2009; COOKE; GIDLEY, 1992; ZOBEL, 1988).

$\mathrm{Na}$ sequência ocorrem os seguintes eventos: as hélices desemparelhadas absorvem água, o grau de inchamento aumenta, os poros na superfície do grânulo abrem, as moléculas de amilose escapam e, neste instante, o característico aumento da viscosidade ocorre (JUSZCZAK; FORTUNA; KROK, 2003; PÉREZ et al, 2009). Sem resistência à deformação, o grânulo se rompe, os demais componentes se dispersam na água e os fragmentos de grânulos se solubilizam totalmente se a temperatura ultrapassar $90^{\circ} \mathrm{C}$ (Al; JANE, 2015; COOKE; GIDLEY, 1992; ZOBEL, 1988).

Ghiasi, Hoseney e Varriano-Marston (1982) aqueceram suspensões de amido de trigo na razão mássica água:amido 2,0 à taxa de $10{ }^{\circ} \mathrm{C} \mathrm{min}^{-1} \mathrm{em}$ um calorímetro diferencial de fluxo de calor até a temperatura de $57^{\circ} \mathrm{C}, 64^{\circ} \mathrm{C}$ e $67^{\circ} \mathrm{C}$. Os autores apresentaram micrografias de campo claro e de luz polarizada (Figura 7) das suspensões gelatinizadas, que ilustram a relação entre o grau de inchamento dos grânulos e a perda do sinal de birrefringência na gelatinização induzida pelo aumento da temperatura.

O desaparecimento do sinal de birrefringência está relacionado com a fusão dos cristais de amilopectina e a água absorvida pelas partes, antes cristalinas, da amilopectina é que causam o grau máximo de inchamento do grânulo antes da ruptura (BILIADERIS, 2009; OOSTEN, 1982). 
Figura 7 - Relação entre o inchamento do grânulo e o sinal de birrefringência da suspensão do amido de trigo-água (1:2) aquecida a taxa de $10^{\circ} \mathrm{C} \mathrm{min}^{-1}$.

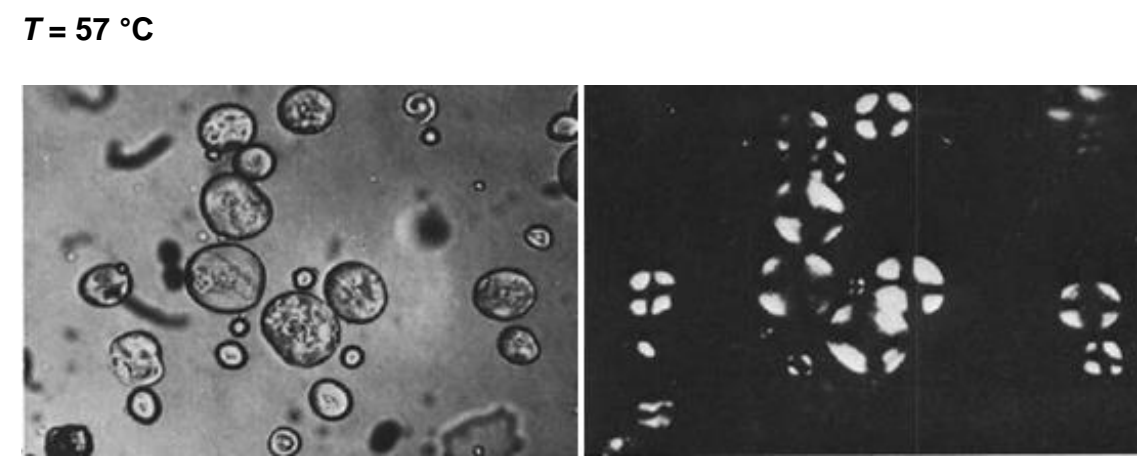

$T=64^{\circ} \mathrm{C}$
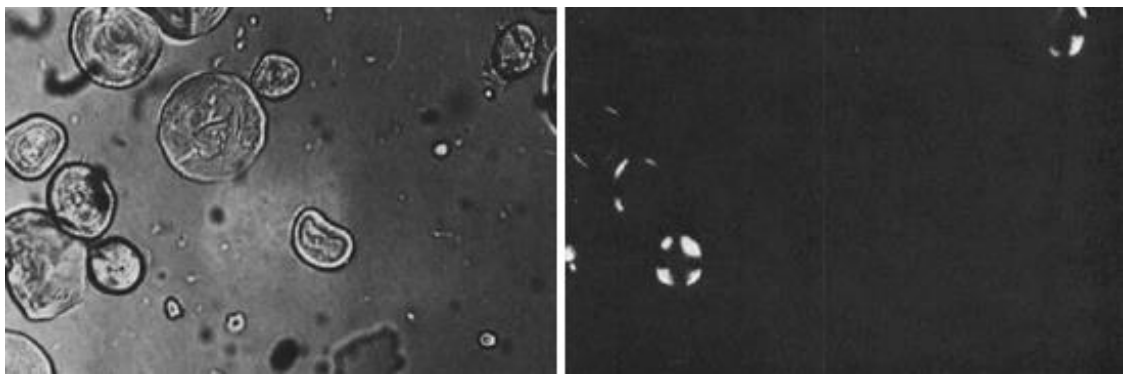

$T=67^{\circ} \mathrm{C}$

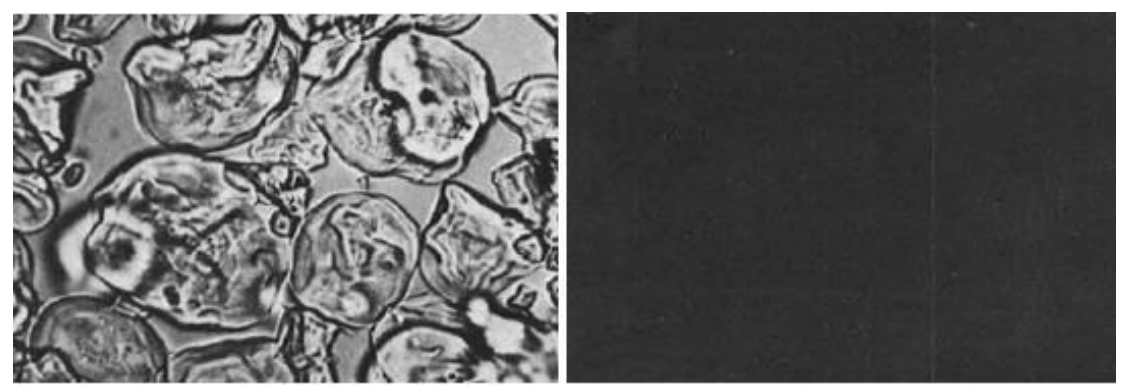

Fonte: Adaptado de Ghiasi, Hoseney e Varriano-Marston (1982).

Cada mudança estrutural ocorre em escala de tempo e condição diferentes, nem todas as alterações moleculares podem ser observadas de uma única vez, algumas estão ocultas e outras não ocorrem (FLORY, 1953; RANDZIO et al., 2002; VAMADEVAN et al., 2013).

Em sistemas amido-água com teor de água próximo de 70 a 80 mg/100 mg e gelatinizados lentamente $\left(\sim 1^{\circ} \mathrm{C} \mathrm{min}^{-1}\right)$ as moléculas de amilopectina se dispersam na água de modo ordenado em uma fase entre o estado sólido (cristalino) e o líquido (isotrópico) chamada de cristal líquido. Variações no alinhamento e na posição das 
moléculas marcam as transições entre fases de cristais líquidos (FISCH; KUMAR, 2001; FLORY, 1984; RANDZIO et al., 2002).

Primeiro, as moléculas de amilopectina estão organizadas com os eixos mais ou menos paralelos na mesma posição e voltados para uma mesma direção, formando faixas que, por sua vez, se alinham uma em relação a outra como uma estrutura em camadas (fase smética). Depois, elas se desorganizam na posição, as camadas não existem mais, contudo continuam apontando para uma mesma direção (fase nemática). Por último, se dispersam de modo aleatório (fase isotrópica) e o sistema torna-se um coloide-sol (FISCH; KUMAR, 2001; FLORY, 1984; RANDZIO et al., 2002).

As quantidades de energia envolvidas nas transições estruturais durante a gelatinização servem para avaliar a estabilidade térmica do grânulo. Do ponto de vista prático, a entalpia de gelatinização $\left(\Delta_{\mathrm{m}} H\right)$ corresponde à energia necessária para liberar e desemparelhar as hélices duplas da rede cristalina e a temperatura de fusão dos cristais corresponde à temperatura de gelatinização $\left(T_{\mathrm{m}}\right)$ (BILIADERIS, 2009; COOKE; GIDLEY, 1992; JANE, 1993; RANDZIO et al., 2002; VAMADEVAN et al., 2013).

O efeito das interações íon-molécula sobre as propriedades físicas do grânulo varia com o tipo de íon, a concentração e a densidade de carga (BILIADERIS, 2009; GOUGH; PHYBUS, 1973; JANE, 1993; OOSTEN, 1982; OOSTEN, 1990). Um ou mais grupos hidroxila $(-\mathrm{OH})$ se dissocia na água, as moléculas de amido adquirem carga negativa
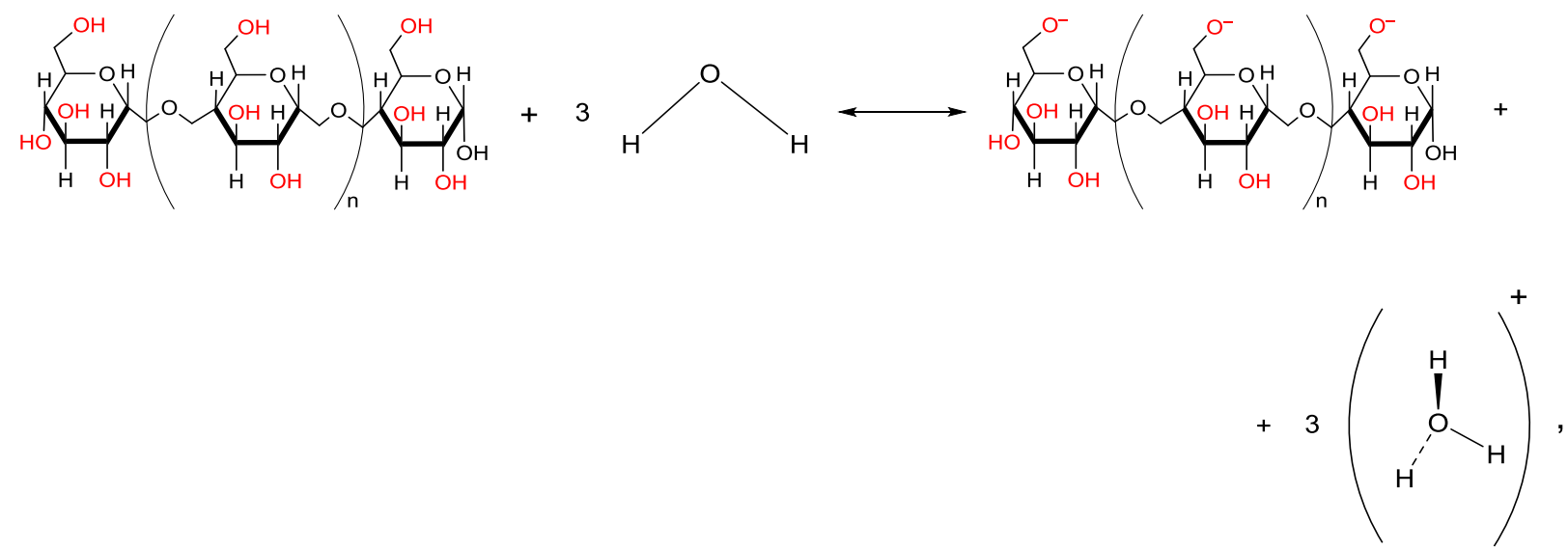

interagem com íons e certos íons induzem alterações estruturais semelhantes àquelas causadas pelo aumento de temperatura (BILIADERIS, 2009; GOUGH; PHYBUS, 1973; JANE, 1993). Se a concentração dos íons $\mathrm{H}_{3} \mathrm{O}^{+}(\mathrm{aq})$ diminuir no interior do 
grânulo, o desequilíbrio de cargas gera forças de repulsão que deformarão as moléculas do amido, fazendo o grânulo inchar (BILIADERIS, 2009; JANE, 1993).

Nestas circunstâncias, o inchamento dependerá da distribuição das cargas negativas nas moléculas de amilopectina e um comportamento único de inchamento não existe mais. O grânulo pode aumentar uniformemente de volume, aumentar em direções preferenciais, ou apenas a camada mais externa pode aumentar de volume (GOUGH; PHYBUS, 1973).

A depender da concentração dos íons, da densidade de carga e da pressão osmótica sobre o grânulo, a camada mais externa também pode gelatinizar. A gelatinização induzida por íons ocorre porque o ponto de fusão dos cristais de amilopectina diminui. O abaixamento da temperatura de gelatinização é maior em amidos com cristais hexagonais quando ânions capazes de interagir eletrostaticamente com a água dos cristais estão difundindo da suspensão para o interior do grânulo (OOSTEN, 1982; OOSTEN, 1990).

Os ânions desestruturam as ligações das 18 moléculas de água no interior de cada cristal, as moléculas ganham movimento e água flui pela rede cristalina, diluindo a fase fundida de amilopectina que começa a se formar. A água do interior dos cristais é o diluente que causa a queda do ponto de fusão da amilopectina conforme previsto pela teoria do abaixamento do ponto de fusão de Flory (1953) expressa matematicamente por:

$$
\frac{1}{T_{m}}-\frac{1}{T_{m}^{0}}=\left(\frac{R}{\Delta_{m} H}\right)\left(\frac{v_{U}}{v_{1}}\right)\left(v_{1}-\chi_{1} v_{1}^{2}\right),
$$

em que $T_{\mathrm{m}}$ é a temperatura de fusão ou gelatinização se água (ou uma impureza) estiver presente na fase fundida, $T_{m}^{0}$ é a temperatura de fusão do polímero puro, $\mathrm{R}$ é a constante dos gases, $\Delta \mathrm{m} H$ é a variação de entalpia de fusão ou gelatinização por mol de unidade polimérica, vu é o volume molar da unidade polimérica, v1 é o volume molar da água, $v_{1}$ é a fração volumétrica da água e $\chi_{1}$ é o parâmetro de interação.

O efeito diluente da água e o desestruturante dos ânions sobre as moléculas de água dos cristais se somam e a temperatura de gelatinização diminui mais rápido conforme a concentração dos ânions aumenta na suspensão (JANE, 1993). 
As transições estruturais que ocorrem na gelatinização definem os usos industriais do amido. Uma forma de controlar o comportamento das moléculas do amido na gelatinização é alterando sua estrutura química (SINGH; KAUR; MCCARTHY, 2007; ZOBEL, 1988).

Dessa forma, o inchamento do grânulo pode ser inibido, a solubilização dos componentes do amido pode ser retardada e as propriedades reológicas de pasta ou de gel do amido podem ser ajustadas às demandas da aplicação (CHEN et al., 2015; JAROWENKO, 1986, MOSER, 1986; SINGH; KAUR; MCCARTHY, 2007).

\subsubsection{Modificação química}

A modificação química do amido consiste em substituir grupos $(-\mathrm{OH})$ nos carbonos 2, 3 e 6 das unidades de anidroglicose por outros grupos funcionais para atribuir características químicas às moléculas do amido ou para controlar as propriedades físicas do grânulo (MASINA et al., 2017; SINGH; KAUR; MCCARTHY, 2007). No caso dos derivados de amido grau alimentício e farmacêutico, a razão molar de substituição deve ser menor que 0,5 e a integridade do grânulo deve ser preservada (FDA, 2017).

Nessa situação, a síntese é conduzida em meio aquoso na presença de $\mathrm{NaOH}$ para facilitar a reação entre as moléculas do amido e as do reagente ativo. Isto é, um sistema amido-água com reação química no qual íons estão difundindo entre a superfície e o interior do grânulo (OOSTEN, 1990).

O grânulo é relativamente grande e compacto com massa específica aproximada de $1,5 \mathrm{~g} \mathrm{~cm}^{-3}$, estas características devem ser consideradas na escolha do reagente ativo e na definição das condições de reação (BILIADERIS, 2009; CHIU; SOLAREK, 2009; JANE, 2009).

Se as moléculas do reagente forem grandes ou difundirem com dificuldade através das camadas do grânulo, as moléculas de amilose e amilopectina na região amorfa da camada mais externa sofrerão maior grau de modificação. Isso já torna o grânulo resistente ao ataque de proteínas e adequado para ser modificado por moléculas-fármaco e ser utilizado como droga polimérica (BESHEER et al., 2007; CHEN et al., 2015; GOLACHOWSKI et al., 2015; SINGH; KAUR; MCCARTHY, 2007; SLEIGHTHOLM et al., 2017; ZHAO et al., 2017). 
Se o propósito da modificação for reforçar a coesão da estrutura do grânulo para controlar o comportamento de inchamento e gelatinização, as moléculas das camadas mais internas também devem ser modificadas por espécies químicas que promovam ligações covalentes entre as moléculas de amilose e amilopectina (JANE, 1994; JANE; RADOSAVLJEVIC; SEIB, 1992; SINGH; KAUR; MCCARTHY, 2007; WURZBURG, 1986).

Para tal fim, as moléculas do reagente devem difundir pelas camadas do grânulo e atingir regiões onde as moléculas de amilose e amilopectina estão próximas o suficiente (4 a 7,5 ̊̊) uma da outra e as condições do meio interno do grânulo favoreça à formação de ligações cruzadas (KASEMSUWAN; JANE, 1994; JANE, 2009; JANE; RADOSAVLJEVIC; SEIB, 1992; SINGH; KAUR; MCCARTHY, 2007).

\subsubsection{Reticulação}

De acordo com a literatura, o cloreto de fosforila $\left(\mathrm{POCl}_{3}\right)$ e o trimetafosfato trisódio $\left(\mathrm{Na}_{3} \mathrm{O}_{9} \mathrm{P}_{3}\right)$ são os agentes de ligação cruzada, ou de reticulação, mais usados para sintetizar derivados de grau alimentício e farmacêutico (BILIADERIS, 2009; CHEN et al., 2015; HEINZE; LIEBERT; KOSCHELLA, 2003; LACK et al., 2007; SINGH; KAUR; MCCARTHY, 2007).

O trimetafosfato trisódio é um sal com estrutura molecular cíclica que foi proposto como promotor de ligação cruzada entre as moléculas de amido na década de 60 (KERR; CLEVELAND, 1962; WURZBURG, 1982). Atualmente, ele é o reagente preferencial quando o objetivo é testar polissacarídeos reticulados como biomateriais (AGUIAR, 2014; BEJENARU et al., 2009; DULONG et al., 2011; LACK et al., 2007).

Lack et al. (2007) estudaram a reação de polissacarídeos com o trimetafosfato trisódio em meio alcalino na presença de $\mathrm{NaOH}(\mathrm{aq})$ por espectroscopia de ressonância magnética nuclear e propuseram um mecanismo com cinco reações químicas-dependentes do $\mathrm{pH}$; da atividade dos íons $\mathrm{H}_{3} \mathrm{O}^{+}, \mathrm{OH}^{-}, \mathrm{Na}^{+}, \mathrm{P}_{3} \mathrm{O}_{9}{ }^{3-}, \mathrm{P}_{2} \mathrm{O}_{7}{ }^{4-}$ e $\mathrm{P}_{3} \mathrm{O}_{10}{ }^{5-}$ e da força iônica do meio de reação-as quais estão descritas a seguir:

- Formação do alcóxido: íons $\mathrm{Na}^{+}(\mathrm{aq})$ se ligam às hidroxilas dissociadas das moléculas do polissacarídeo, formando o alcóxido 
$\begin{array}{ccc}\mathrm{ROH}_{(\mathrm{aq})}+\quad \mathrm{NaOH}_{(\mathrm{aq})} \longrightarrow & \mathrm{RONa}_{(\mathrm{aq})} \cdot \\ \text { Polissacarídeo } & \text { Hidróxido de sódio } & \text { Alcóxido }\end{array}$

- Formação do tripolifosfato de sódio enxertado na molécula do polissacarídeo: a espécie alcóxido se liga à molécula do trimetafosfato trisódio, abrindo o anel. A molécula do polissacarídeo se liga a uma extremidade e à outra o $\mathrm{Na}^{+}(\mathrm{aq})$

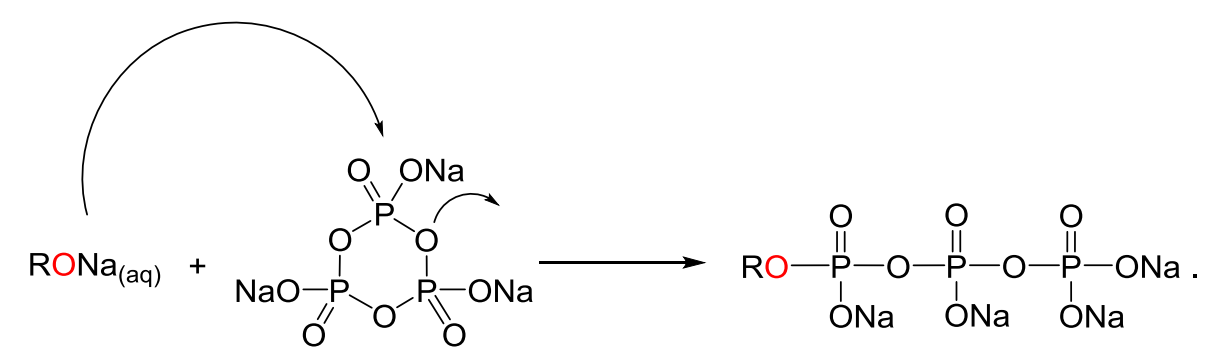

Alcóxido Trimetafosfato trisódio Tripolifosfato de sódio enxertado

- Formação do diéster de fosfato (reticulação): a espécie alcóxido se liga ao tripolifosfato de sódio enxertado, formando um diéster de fosfato que une, como se fosse uma ponte, as moléculas do polissacarídeo. O pirofosfato inorgânico é gerado como subproduto

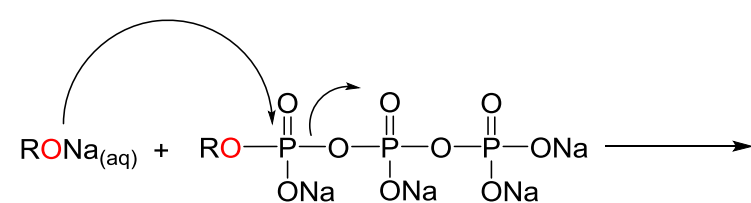

Alcóxido

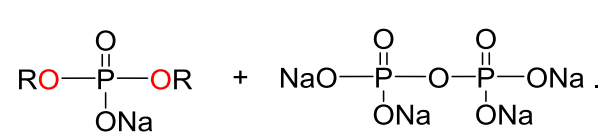

Diéster (cross-link) Pirofosfato inorgânico

As demais reações ocorrem se o $\mathrm{NaOH}(\mathrm{aq})$ estiver em excesso em relação ao trimetafosfato trisódio, desfavorecendo a reticulação das moléculas do polissacarídeo.

- $\quad$ Formação do monoéster de fosfato: 0 íon $\mathrm{Na}^{+}(\mathrm{aq})$ em excesso se liga à molécula do tripolifosfato de sódio enxertado na molécula do polissacarídeo, formando o monoéster e o pirofosfato inorgânico 


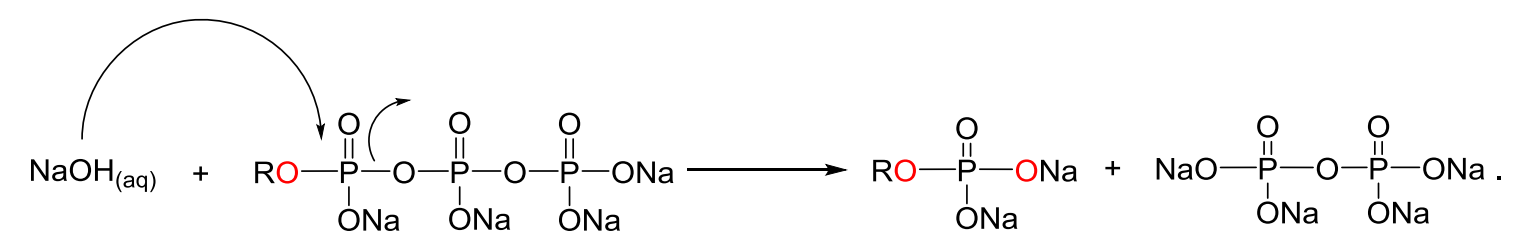

Hidróxido de sódio Tripolifosfato de sódio enxertado Monoéster Pirofosfato inorgânico

- Degradação do trimetafosfato trisódio: os íons $\mathrm{Na}^{+}(\mathrm{aq})$ e $\mathrm{OH}^{-}$em excesso preferencialmente se ligam, abrindo o anel, às extremidades da molécula do trimetafosfato trisódio e formam o tripolifosfato de sódio

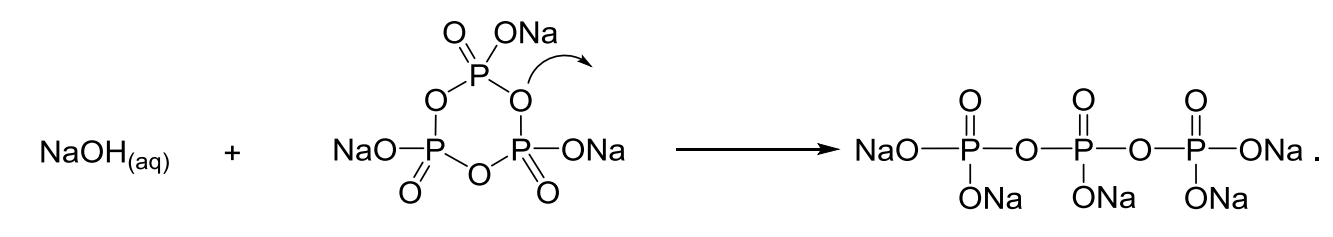

É fato relevante que, os dados experimentais para esse mecanismo foram da reticulação do monossacarídeo metil-a-D-glicopiranosídeo $\left(\mathrm{C}_{7} \mathrm{H}_{14} \mathrm{O}_{6}\right)$ e o pululano foi o polissacarídeo utilizado para validar o mecanismo de reação (DULONG et al., 2011; LACK et al., 2007). Posteriormente, os pesquisadores estudaram a reticulação da goma xantana por meio desse mesmo mecanismo (BEJENARU et al., 2009). É fato relevante também que, os polissacarídeos estudados não são constituídos por mais de um tipo de molécula que se arranjam diferentemente em uma única estrutura semelhante ao grânulo do amido (HEINZE; LIEBERT; KOSCHELLA, 2003).

Reticular as moléculas do amido com trimetafosfato trisódio requer monitoramento e controle do $\mathrm{pH}$ do meio para acompanhar a evolução da reação, a difusão dos íons através do grânulo e a interação desses íons com as moléculas do amido, prevenindo a ruptura do grânulo (BILIADERIS, 2009; CHIU; SOLAREK, 2009).

\subsubsection{Acetilação}

A acetilação é um tipo de modificação do amido que requer também monitoramento com controle das condições do meio de reação (CHIU; SOLAREK, 
2009; JAROWENKO, 1986; JETTEN; STAMHUIS; JOOSTEN, 1980). Na acetilação, os grupos $(-\mathrm{OH})$ nas unidades de anidroglicose são esterificados por meio da reação do amido com acetato de vinila ou com anidrido acético com o intuito de inserir grupos acetila $\left(\mathrm{CH}_{3} \mathrm{CO}-\right)$ nas moléculas do amido (GOLACHOWSKI et al., 2015; JAROWENKO; 1986).

A razão molar de substituição dos derivados acetilados grau farmacêutico dever ser menor que 0,2 para não comprometer a estrutura do grânulo (FDA, 2017; GOLACHOWSKI et al., 2015; JAROWENKO, 1986; MASINA et al., 2017). De acordo com a literatura, a razão molar de substituição depende do tipo de amido, do reagente ativo, da proporção dos reagentes, do tempo de reação, e do $\mathrm{pH}$ e da temperatura do meio de acetilação (GOLACHOWSKI et al., 2015; JAROWENKO, 1986).

Por isso, as reações de acetilação são conduzidas em sistemas de batelada alimentada nos quais o reagente ativo é adicionado a uma suspensão aquosa de amido e o pH é mantido na faixa de 8,0 a 8,5 para facilitar a acetilação e evitar a hidrólise das moléculas (CHIU; SOLAREK, 2009; JAROWENKO, 1986; JETTEN; STAMHUIS; JOOSTEN, 1988; HUNG; MORITA, 2005; PHILLIPS et al., 1999; SINGH, KAUR, MCCARTHY; 2007).

$\mathrm{O}$ pH normalmente é controlado pela adição de $\mathrm{NaOH}$ (aq) (JAROWENKO, 1986; JETTEN; STAMHUIS; JOOSTEN, 1988; HUNG; MORITA, 2005; PHILLIPS et al., 1999;). Na acetilação do amido com anidrido acético, parte do $\mathrm{NaOH}(\mathrm{aq})$ gasto no controle do $\mathrm{pH}$, é usado para neutralizar o ácido acético formado na acetilação

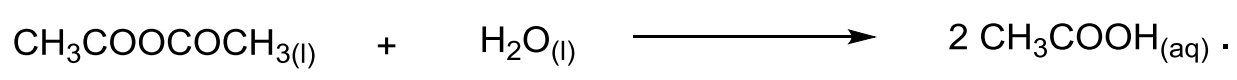

Anidrido acético Ácido acético

As moléculas do anidrido acético, que não formam o ácido acético, reagem com as moléculas do amido. As hidroxilas dissociadas na molécula do amido reagem com o íon $\mathrm{Na}^{+}(\mathrm{aq})$, formando o alcóxido de amido

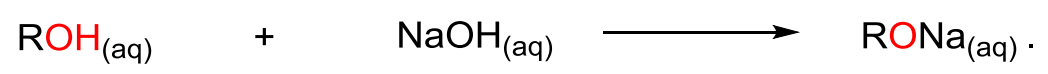

$\begin{array}{lll}\text { Amido } & \text { Hidróxido de sódio } & \text { Alcóxido }\end{array}$ 
O alcóxido de amido reage com o anidrido acético, ligando-se ao radical acetila, e formando o acetato de amido

$\begin{array}{cccc}\mathrm{RONa}_{(\mathrm{aq})}+\mathrm{CH}_{3} \mathrm{COOCOCH}_{3(\mathrm{l})} \longrightarrow & \mathrm{ROCOCH}_{3(\mathrm{aq})}+ & \mathrm{CH}_{3} \mathrm{COONa}_{(\mathrm{aq})} . \\ \text { Alcóxido de amido } & \text { Anidrido acético } & \text { Acetato de amido } & \text { Acetato de sódio }\end{array}$

A adição descasada de $\mathrm{CH}_{3} \mathrm{COOCOCH}_{3}(\mathrm{l})$ e de $\mathrm{NaOH}(\mathrm{aq})$ causa oscilações de $\mathrm{pH}$ que comprometem a estrutura do grânulo. A adição em excesso de $\mathrm{NaOH}(\mathrm{aq})$ provoca o inchamento do grânulo e a acidificação recorrente do meio provoca a erosão do grânulo (GOLACHOWSKI et al., 2015; HUNG; MORITA, 2005; JAROWENKO; 1986).

O efetivo controle do $\mathrm{pH}$ é alcançado quando a taxa de alimentação do reagente é controlada ou mantida constante. O sistema de controle assim definido, além de manter as condições do meio de acetilação seguras para o grânulo, estabelece o tempo de alimentação do reagente e, como consequência, o tempo de reação do sistema (GOLACHOWSKI et al., 2015; HAN et al., 2012; JETTEN; STAMHUIS; JOOSTEN, 1988).

\subsubsection{Abordagem experimental}

A literatura específica sobre amido quimicamente modificado trata o sistema de reação como uma caixa—preta, estudando a modificação química com base somente em dados de caracterização dos derivados e colocando as consequências das condições no meio de reação sobre as moléculas do amido em segundo plano (AGUIAR, 2014; BEJENARU et al., 2009; DULONG et al., 2011; HUANG et al., 2006; HUNG; MORITA, 2005; JAROWENKO, 1986; LACK et al., 2007; PHILLIPS et al., 1999; SINGH, KAUR, MCCARTHY; 2007).

A maioria dos estudos avaliados não descreveu como o $\mathrm{pH}$ foi controlado nem informou o tempo de reação (HUANG et al., 2006; HUNG; MORITA, 2005; PHILLIPS et al., 1999; SINGH, KAUR, MCCARTHY; 2007). Huang et al. (2006) apenas informaram as proporções entre os reagentes e acetilaram o amido de feijão verde em um laboratório externo. 
Uma exceção foi o trabalho de Jetten, Stamhuis e Joosten (1980) no qual os pesquisadores descreveram um sistema de controle do $\mathrm{pH}$ do meio de acetilação do amido de batata com acetato de vinila. O sistema comparava o valor de leitura enviado por um pHmetro com o valor de referência e enviava um sinal para ligar o motor de uma bureta automática que dispensava $\mathrm{NaOH}(\mathrm{aq})$ no meio de reação.

Os protocolos de reticulação e acetilação do amido datam das décadas de 50 e 60 quando não se falava de instrumentação científica de baixo custo, de programas de computador e de hardware para integrar e controlar equipamentos de laboratório (JAROWENKO, 1986; KERR; CLEVELAND, 1962; MABBOTT, 2014; PHILLIPS et al., 1999; WURZBURGH, 1986). Isto explica porque a abordagem caixa-preta domina na literatura sobre a síntese de amido quimicamente modificado (HUANG et al., 2006; PHILLIPS et al., 1999; SINGH, KAUR, MCCARTHY; 2007; WUZBURG, 1982).

$\mathrm{O}$ emprego de montagens experimentais automatizadas como unidades de síntese de derivados de amido se torna uma alternativa graças à disponibilidade de hardware livres, e de programas para a aquisição de dados com interfaceamento para equipamentos e instrumentos de laboratório (GALAS; HAGHIRI-GOSNET; ESTÉVEZTORRES, 2013; GRINIAS et al., 2016; KALKMAN, 1995; MABBOTT, 2014; PEARCE, 2014). 


\section{MATERIAIS E MÉTODOS}

\subsection{MATERIAIS}

A matéria-prima utilizada nos experimentos foi o amido de mandioca nativo (AMILOGILL1500 lote 201605005M, Cargill, Brasil) diretamente obtido da fecularia e cuja composição é mostrada na Tabela 1.

Tabela 1 - Composição do amido de mandioca nativo utilizado nos experimentos de reticulação e acetilação

\begin{tabular}{lcc}
\hline & \multicolumn{2}{c}{ Teor e método de análise } \\
\cline { 2 - 3 } Componente & Valor & Norma \\
\hline Amido $(\mathrm{g} / 100 \mathrm{~g})$ & $83,7 \pm 1,3$ & AACC $76-11$ \\
Umidade $(\mathrm{g} / 100 \mathrm{~g})$ & $13,2 \pm 0,2$ & ISO $1666-1997$ \\
Proteínas $(\mathrm{g} / 100 \mathrm{~g})$ & $<$ limite & AOAC 960.52 \\
Lipídios totais $(\mathrm{g} / 100 \mathrm{~g})$ & $0,28 \pm 0,05$ & AACC $30-25$ \\
Cinzas $(\mathrm{g} / 100 \mathrm{~g})$ & $0,08 \pm 0,02$ & ISO 3593 -1981 \\
\hline
\end{tabular}

Fonte: Elaborado pela autora (2019).

$\mathrm{O}$ agente de reticulação foi 0 trimetafosfato trisódio $\left(\mathrm{Na}_{3} \mathrm{P}_{3} \mathrm{O}_{9}\right.$, pureza > 95 g/100 g, CAS 7785-84-4, Sigma Aldrich, Brasil) e o agente de acetilação foi o anidrido acético $\left(\left(\mathrm{CH}_{3} \mathrm{CO}\right)_{2} \mathrm{O}, \geq 97 \mathrm{~mL} / 100 \mathrm{~mL}\right.$, CAS 108-24-7, Synth, Brazil).

\subsubsection{Síntese do amido de mandioca quimicamente modificado}

As amostras de cada experimento foram identificadas por um mesmo código. A letra $R$ indica que a amostra foi reticulada e quando acompanhada da letra $A(R A)$ indica que foi reticulada e depois foi acetilada. Os números de 1 a 4 indicam a condição de reação de síntese do derivado reticulado e as réplicas foram identificadas somando-se quatro a esses números—por exemplo, $R_{1}, R_{5}$, $R_{9}$ e assim por diante. 
Todos foram sintetizados na condição de reação \#1—os números também identificam o par acetilado da amostra reticulada, por exemplo, $\mathrm{R}_{1}$ e $\mathrm{RA}_{1}$.

Os derivados reticulados foram sintetizados em quatro condições reacionais segundo um planejamento $2^{2}$ fatorial no qual as variáveis independentes foram o $\mathrm{pH}$ do meio de reação e a razão molar de trimetafosfato de trisódio por unidade de anidroglicose (RSTMP:AGU) e as variáveis dependentes foram os parâmetros de gelatinização.

Os limites das variáveis independentes foram definidos a partir do estudo de Aguiar (2014) no qual o amido de mandioca nativo foi reticulado em diferentes proporções molares de trimetafosfato trisódio por unidade de anidroglicose 0 a 0,16 , mantendo-se constantes o pH, a temperatura e o tempo de reação em $11,0,50{ }^{\circ} \mathrm{C}$, $5,0 \mathrm{~h}$, respectivamente. O limite inferior do $\mathrm{pH}$ do meio de reticulação foi definido com base no estudo de Lack et al. (2007).

A matriz do planejamento de experimentos empregado para avaliar o efeito do $\mathrm{pH}$ e o da quantidade de trimetafosfato trisódio sobre os parâmetros de gelatinização do amido reticulado é mostrada na Tabela 2.

Tabela 2 - Matriz do planejamento experimental $2^{2}$ fatorial com quatro réplicas $(N=4)$, identificando as condições do meio de reticulação dos experimentos de síntese do amido de mandioca reticulado

\begin{tabular}{|c|c|c|c|c|c|c|}
\hline \multicolumn{2}{|c|}{$\begin{array}{c}\text { Experimentos de síntese dos } \\
\text { derivados }\end{array}$} & \multicolumn{2}{|c|}{ Níveis das variáveis } & \multicolumn{3}{|c|}{$\begin{array}{l}\text { Variáveis } \\
\text { codificadas }\end{array}$} \\
\hline Identificação & Amostras & $\mathrm{pH}(\mathrm{A})$ & $R_{\text {STMP:AGU }}{ }^{(1)}(\mathrm{B})$ & A & $B$ & $A B$ \\
\hline$\# 1$ & $R_{1}, R_{5}, R_{9}$ e $R_{13}$ & 10,0 & 0,03 & - & - & + \\
\hline \#2 & $R_{2}, R_{6}, R_{10}$ e $R_{14}$ & 11,0 & 0,03 & + & - & - \\
\hline \#3 & $R_{3}, R_{7}, R_{11}$ e $R_{15}$ & 10,0 & 0,08 & - & + & - \\
\hline \#4 & $R_{4}, R_{8}, R_{12}$ e $R_{16}$ & 11,0 & 0,08 & + & + & + \\
\hline
\end{tabular}

Fonte: Elaborado pela autora (2019).

(1) O número de mol de unidades de anidroglicose foi estimado dividindo a massa de amido desidratada pela massa molecular da anidroglicose $\left(162,14 \mathrm{~kg} \mathrm{kmol}^{-1}\right)$ e excluindo as unidades nas pontas das moléculas, as moléculas de água internas às regiões cristalinas e as adsorvidas na região amorfa, e outros componentes minoritários.

Os derivados reticulados de amido de mandioca foram acetilados com anidrido acético sob pH controlado de 8,4, razão molar de anidrido acético por unidade de 
anidroglicose ( $\left.R_{\text {AAc:AGU }}\right)$ de 0,16 e temperatura de $30,0^{\circ} \mathrm{C}$. O esquema mostrado na Figura 8 ilustra a síntese dos derivados de amido de mandioca.

Figura 8 - Esquema ilustrativo da reticulação e posterior acetilação do amido de mandioca.

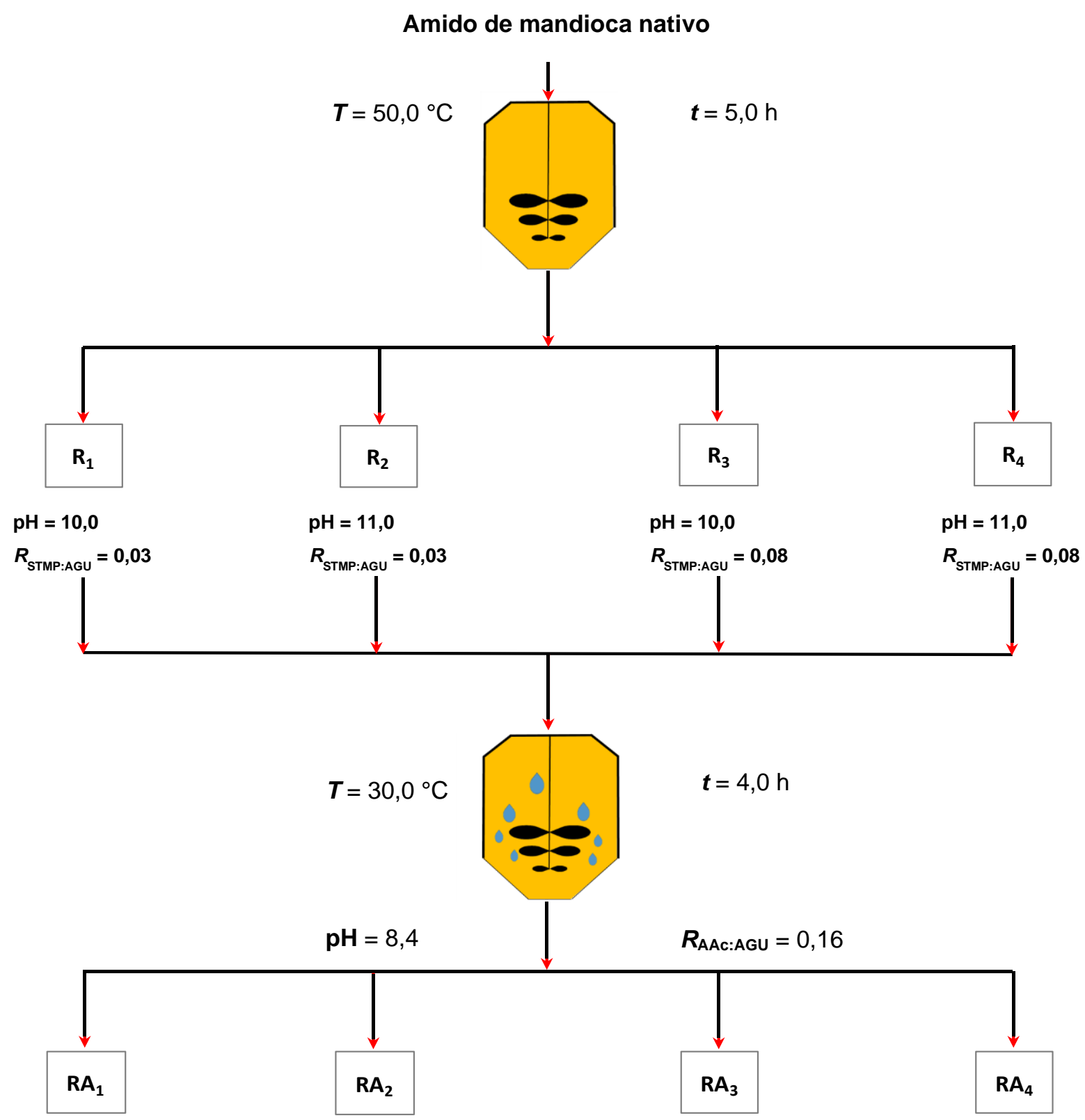

Fonte: Elaborado pela autora (2019).

O protocolo usado para acetilar o derivado reticulado de amido de mandioca foi o descrito por Phillips et al. (1999). Este protocolo foi selecionado porque os 
pesquisadores mostraram que nas proporções de reagentes utilizadas a razão molar de substituição dos derivados foi menor que 0,2.

A montagem experimental impôs mínimas alterações ao protocolo e permitiu especificar o tempo de reação uma vez que o anidrido acético (AAc) foi adicionado a taxa controlada ao meio de reação. A comparação entre o protocolo proposto por Phillips et al. (1999) e o adaptado para este trabalho está apresentada na Tabela 3.

Tabela 3 - Comparação entre as condições do meio de acetilação e de processo da síntese do amido de mandioca acetilado do protocolo original e deste trabalho

\begin{tabular}{lcc}
\hline & \multicolumn{2}{c}{ Protocolo } \\
\cline { 2 - 3 } Condições de processo & 25,0 & 30,0 \\
\hline Temperatura $\left({ }^{\circ} \mathrm{C}\right)$ & $8,0-8,4$ & $8,0-8,5$ \\
$\mathrm{pH}$ & 0,16 & 0,16 \\
$R_{\text {AAc:AGU }}\left(\mathrm{mol} \mathrm{mol}^{-1}\right)$ & $(1)$ & 2,3 \\
Tempo de adição de AAc $(\mathrm{h})$ & $(1)$ & 2,5 \\
Tempo de reação $(\mathrm{h})$ & (1) & 4,0 \\
Tempo de síntese $(\mathrm{h})$ & $(1999)$ &
\end{tabular}

Fonte: Elaborado pela autora (2019).

(1) Não informado.

Nota-se na tabela que o tempo de adição de anidrido acético, uma variável que influencia o grau de acetilação das moléculas do amido, não foi informado pelos pesquisadores acima citados.

A matriz completa dos experimentos é mostrada na Tabela 4 na qual os derivados reticulados e acetilados estão divididos em grupos de acordo com as condições do meio de reticulação. 
Tabela 4 - Matriz completa dos experimentos de síntese dos derivados reticulados e acetilados de amido de mandioca

\begin{tabular}{|c|c|c|c|c|c|}
\hline \multicolumn{2}{|c|}{ Condições de reação } & \multicolumn{2}{|c|}{ Derivados reticulados } & \multicolumn{2}{|c|}{ Derivados acetilados } \\
\hline $\mathrm{pH}$ & $R_{\text {STMP:AGU }}$ & Grupo & Amostras & Grupo & Amostras \\
\hline 10,0 & 0,03 & 1 & $R_{1}, R_{5}, R_{9}$ e $R_{13}$ & 5 & $R A_{1}, R A_{5}, R A_{9}$ e $R A_{13}$ \\
\hline 11,0 & 0,03 & 2 & $R_{2}, R_{6}, R_{10}$ e $R_{14}$ & 6 & $R A_{2}, R A_{6}, R A_{10}$ e $R A_{14}$ \\
\hline 10,0 & 0,08 & 3 & $R_{3}, R_{7}, R_{11}$ e $R_{15}$ & 7 & $R A_{3}, R A_{7}, R A_{11}$ e $R A_{15}$ \\
\hline 11,0 & 0,08 & 4 & $R_{4}, R_{8}, R_{12}$ e $R_{16}$ & 8 & $R A_{4}, R A_{8}, R A_{12}$ e $R A_{16}$ \\
\hline
\end{tabular}

Fonte: Elaborado pela autora (2019).

\subsubsection{Montagem experimental}

Uma montagem experimental foi construída para adicionar automaticamente os reagentes, ler e armazenar dados de $\mathrm{pH}$ e temperatura, e corrigir o $\mathrm{pH}$ do meio da reação. Um projeto foi criado no programa LabVIEW (2014 SPI, National Instruments, Estados Unidos) para atuar como uma central de gerenciamento de todo o sistema e servir de interface entre o usuário e o sistema de reação.

Observa-se na Figura 9 a tela de interface na qual estão mostradas as curvas de evolução do $\mathrm{pH}$ e da temperatura de reação em tempo real. Visualiza-se também o valor de referência do $\mathrm{pH}$, que é introduzido pelo usuário, e o da última leitura do pHmetro. A partir disto, o programa compara ambos valores e calcula um erro enviando um sinal de correção do $\mathrm{pH}$ para o sistema de controle. 
Figura 9 - Tela de interface do programa de monitoramento da temperatura e do pH do meio de reação no LabVIEW.

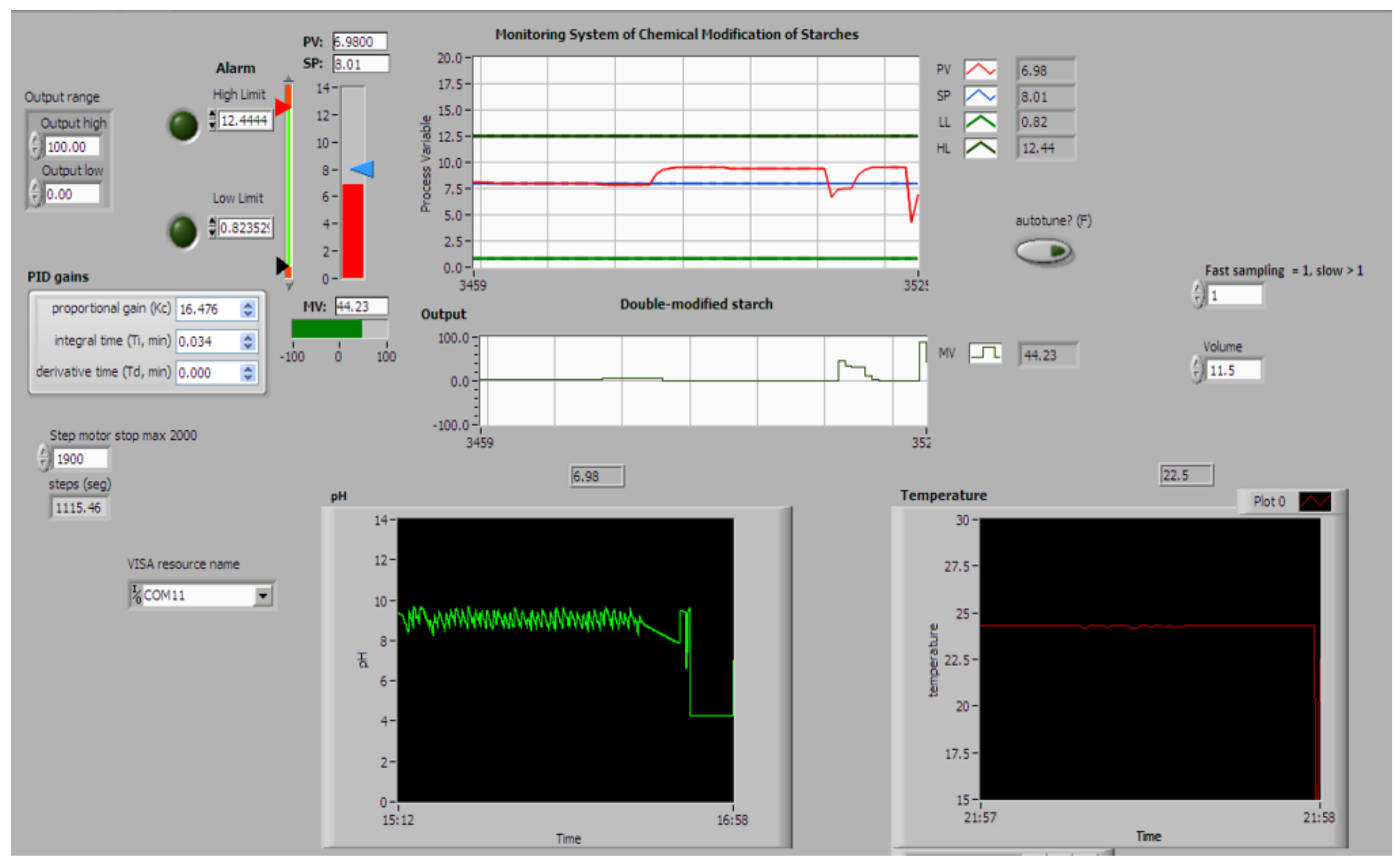


Os experimentos foram conduzidos em um balão de reação de $500 \mathrm{~mL}$ não volumétrico de três bocas. A temperatura do meio reacional foi mantida pela submersão do balão em um banho de água aquecido por intermédio de uma placa de aquecimento elétrico (AA2050, Gehaka, Brasil) e pela homogeneização do meio de reação por uma barra magnética.

Os instrumentos de medição foram o eletrodo de pH (DME-CV2, Digimed, Brasil) e o termopar, os dois acoplados ao pHmetro (TEC-3-MP, Tecnal, Brasil), como ilustrado na Figura 10.

Figura 10 - Desenho ilustrativo do sistema de reação para a síntese do amido de mandioca quimicamente modificado.

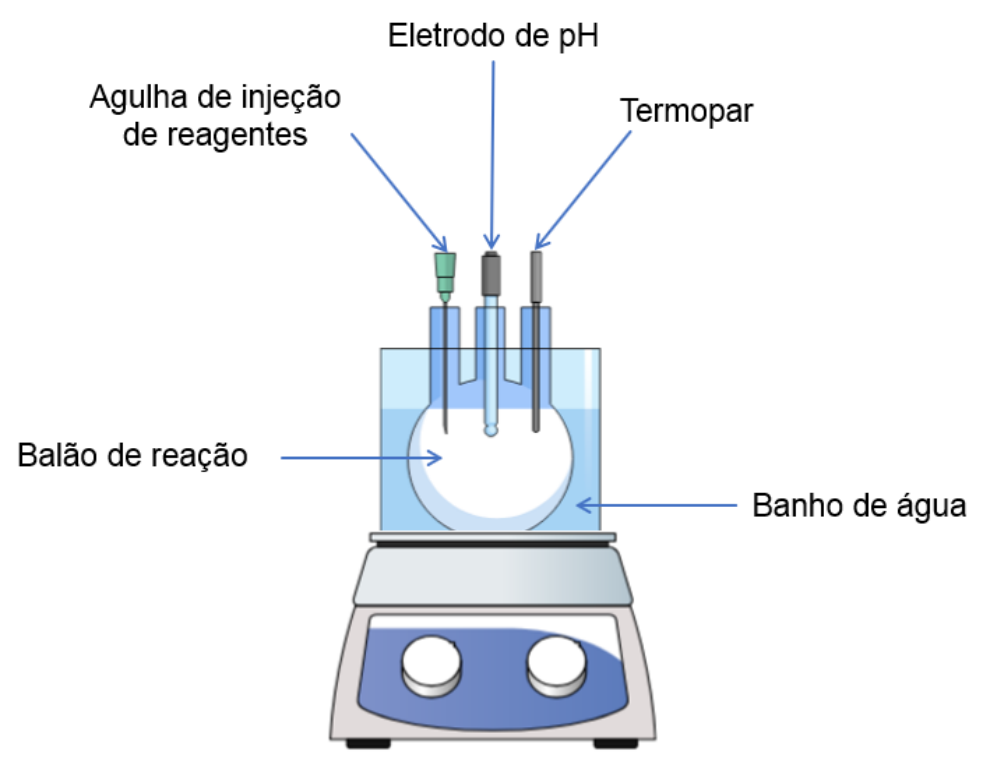

Placa de aquecimento elétrica com agitação magnética

Fonte: Elaborado pela autora (2019).

A adição automática de anidrido acético foi realizada por um dispositivo adaptado de uma peça de scanner para funcionar como um sistema de adição de líquidos por seringa. Para tanto, um suporte para a seringa e um carro de deslocamento para empurrar o êmbolo foram construídos e adaptados na peça, como mostrado na Figura 11. 
Figura 11 - Esquema do sistema de adição automática de anidrido acético.

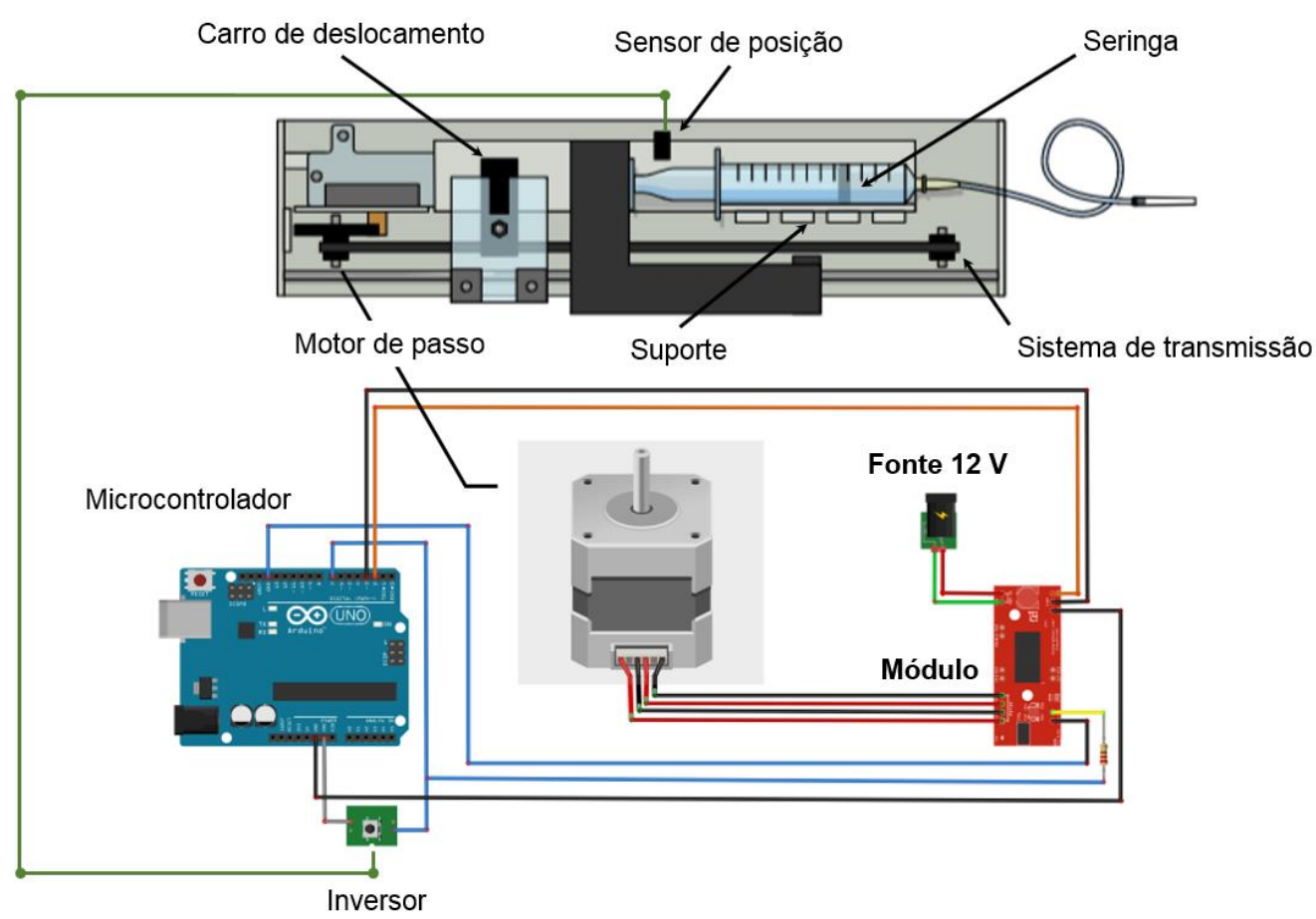

Fonte: Elaborado pela autora (2019).

O sistema foi automatizado por meio da integração de um microcontrolador (Uno SMD R3, Arduino, Itália) a um módulo de motor de passo (v1, EasyDriver, Estados Unidos) e tudo acoplado ao motor (M35SP - 7T, Mitsumi, Japão) do scanner, como mostrado na Figura 11.

O reagente foi alimentado à vazão constante de $23 \mu \mathrm{L} \mathrm{min}{ }^{-1}$. A essência do funcionamento do sistema de dosagem foi manter a alimentação do reagente cadenciada e lenta o suficiente para dar tempo ao sistema de controle atuar e manter o valor do $\mathrm{pH}$ na faixa desejada de 8,0 a 8,5.

$\mathrm{O}$ sistema de controle de $\mathrm{pH}$ atuava por intermédio de uma bomba peristáltica que adicionava a quantidade de base para corrigir o $\mathrm{pH}$. Para isso, um microcontrolador (Uno SMD R3, Arduino, Itália) foi acoplado ao motor da bomba (IPC - 4 v301, Ismatec, Alemanha) por meio de um transistor para ligar a bomba mediante o sinal do controlador do LabVIEW ao microcontrolador, como. representado na Figura 12.

Em relação à programação, o LabVIEW enviava o sinal de controle para o microcontrolador acionar o motor da bomba quando lia valores de $\mathrm{pH}$ inferiores a 8,4. 
Figura 12 - Esquema do sistema de controle do pH do meio de reação.

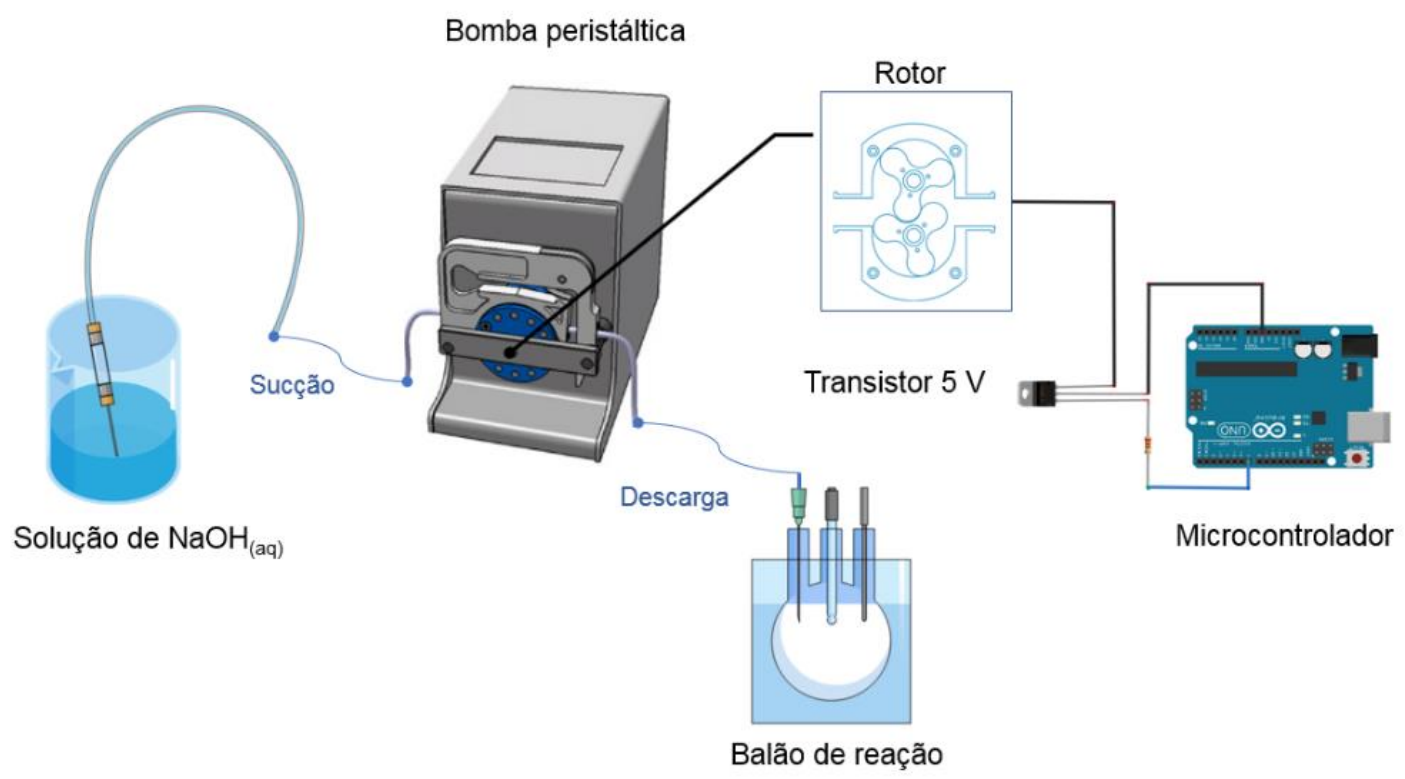

Fonte: Elaborado pela autora (2019).

Um novo sistema semelhante ao de adição de anidrido acético foi construído para adquirir as curvas de consumo de $\mathrm{NaOH}(\mathrm{aq})$ e acompanhar o progresso da acetilação das moléculas do amido de mandioca. Um esquema do sistema está mostrado na Figura 13.

Figura 13 - Esquema do novo sistema de controle do pH do meio de acetilação.

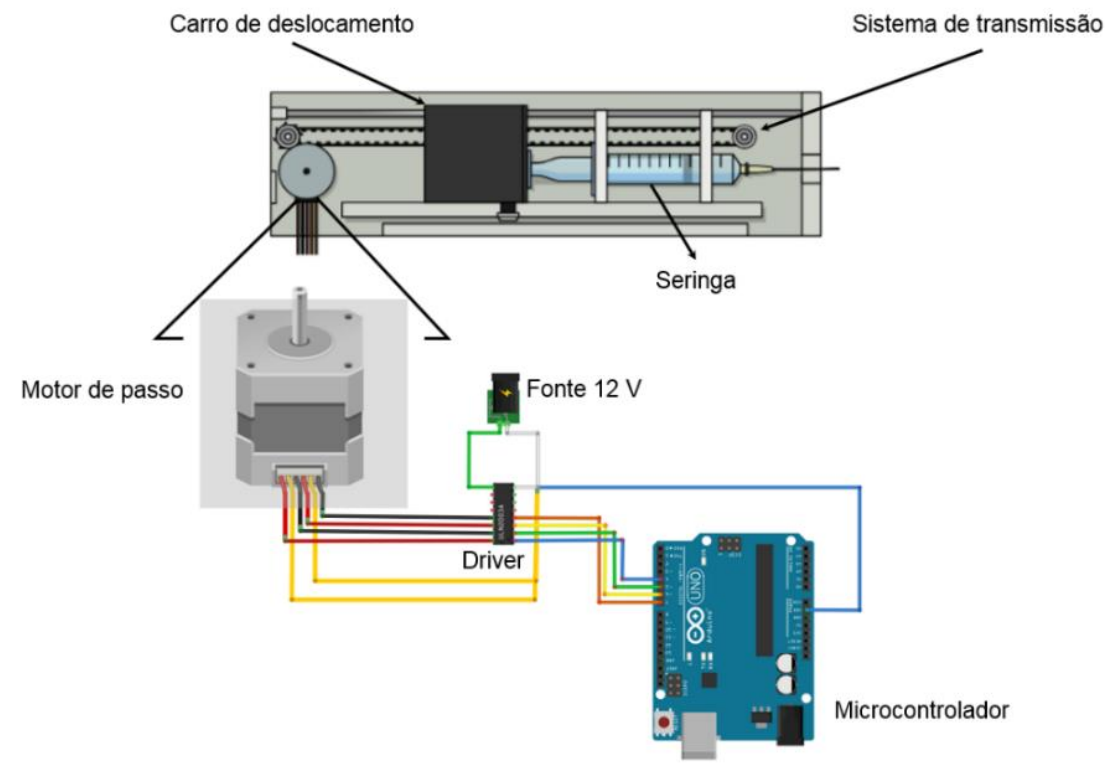

Fonte: Elaborado pela autora (2019). 
Diferentemente do sistema com a bomba, neste o programa do LabVIEW enviava um sinal de controle proporcional ao valor do erro calculado ao microcontrolador que modulava a velocidade do carro de deslocamento e restringia a quantidade de $\mathrm{NaOH}$ (aq) transferida ao balão de reação.

\subsubsection{Protocolo de reticulação}

Amido de mandioca nativo seco ( $65,0 \mathrm{~g} ; 0,40 \mathrm{~mol}$ de unidades de anidroglicose) foi disperso em $350 \mathrm{~mL}$ de água ultrapura tipo III (ASTM, 2018) em temperatura ambiente. A suspensão foi transferida para o balão de reação que foi submerso em banho de água a $50{ }^{\circ} \mathrm{C}$ sob agitação magnética a $750 \mathrm{rpm}$. Depois de $15 \mathrm{~min}$, o termopar e o eletrodo de $\mathrm{pH}$ foram conectados ao balão de reação

Trimetafosfato trisódio $(3,25 \mathrm{~g} ; 0,01 \mathrm{~mol}$ ou $9,75 \mathrm{~g} ; 0,03 \mathrm{~mol})$ foi dissolvido em $100 \mathrm{~mL}$ de água ultrapura tipo III (ASTM, 2018) em temperatura ambiente. A solução foi transferida para o balão de reação por meio de uma bomba dosadora (202, Milan, Brasil).

Após o sistema de reação estabilizar, o pH foi ajustado $(10,0$ ou 11,0$)$ com a adição gota a gota de solução de $\mathrm{NaOH}$ a $0,5 \mathrm{~mol} \mathrm{~L}^{-1}$. A reação foi encerrada após $5 \mathrm{~h}$ com a neutralização do meio com solução de $\mathrm{HCl}$ a $1,0 \mathrm{~mol} \mathrm{~L}^{-1}$.

Todo o processo de síntese do derivado reticulado durou em média $20 \mathrm{~h}$. A síntese propriamente dita, a lavagem e a secagem duravam $5,0 \mathrm{~h} ; 2,5 \mathrm{~h}$ e $12 \mathrm{~h}$, respectivamente.

O amido reticulado foi separado do meio de reação por filtração a vácuo e a torta foi lavada (ressuspensa) três vezes com água ultrapura tipo III (ASTM, 2018) e deixada em uma estufa (N480, Nova Ética, Brasil) para secar a $45^{\circ} \mathrm{C}$ por $12 \mathrm{~h}$.

$\mathrm{O}$ derivado seco foi triturado para desfazer os aglomerados, a massa medida $\mathrm{e}$ colocada em um pote de polipropileno com fechamento hermético e acondicionado à temperatura ambiente protegido da luz em um dessecador. O diagrama de blocos da Figura 14 mostra as etapas do experimento de reticulação do amido nativo. 
Figura 14 - Diagrama de blocos das etapas dos experimentos de reticulação do amido de mandioca nativo.

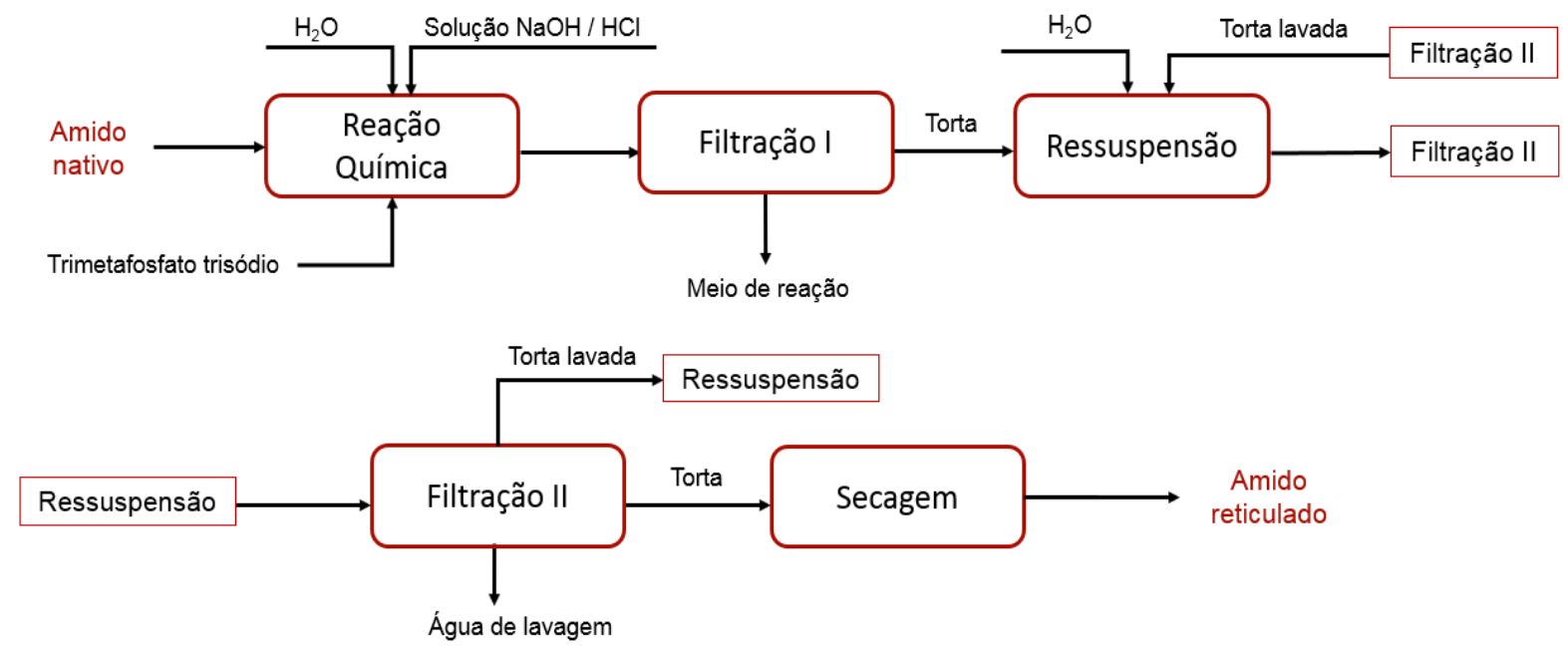

Fonte: Elaborado pela autora (2019).

Os parâmetros de gelatinização do amido reticulado de mandioca em cada condição foram determinados em duplicata por meio de curvas de microcalorimetria exploratória diferencial, o teor de umidade foi determinado em duplicata de acordo com a norma DIN EN ISO 166:1997 e a estrutura molecular foi avaliada por espectroscopia de absorção no infravermelho e por microscopia Raman

\subsubsection{Protocolo de acetilação}

Amido reticulado (30,0 g; 0,19 mol de unidades de anidroglicose) foi disperso em $300 \mathrm{~mL}$ de água ultrapura tipo III (ASTM, 2018) em temperatura ambiente. A suspensão foi transferida para o balão de reação, ao qual foram conectados os instrumentos de medição.

A suspensão foi homogeneizada por $60 \mathrm{~min}$ a $30^{\circ} \mathrm{C}$. Depois o $\mathrm{pH}$ do meio foi ajustado para $8,4 \mathrm{com}$ solução de $\mathrm{NaOH}$ a $0,5 \mathrm{~mol} \mathrm{~L}^{-1}$. O anidrido acético $(3,0 \mathrm{~mL}$; $0,03 \mathrm{~mol}$ ) foi transferido a taxa constante para o balão de reação, enquanto o sistema de controle mantinha o pH alcalino. Finalizada a alimentação, a reação foi mantida por 15 min. A reação foi encerrada com a acidificação do meio, reduzindo o pH para 4,5 com solução de $\mathrm{HCl}$ a $1,0 \mathrm{~mol} \mathrm{~L}^{-1}$. 
O derivado foi filtrado a vácuo e a torta lavada com água ultrapura tipo III (ASTM, 2018). A torta foi ressuspensa em água duas vezes e uma vez (lavagem intermediária) em álcool etílico para remover impurezas orgânicas. O derivado foi deixado em uma estufa (N480, Nova Ética, Brasil) a $45{ }^{\circ} \mathrm{C}$ por 12 h. As etapas do experimento de acetilação do amido reticulado estão mostradas no diagrama de blocos da Figura 15.

Figura 15- Diagrama de blocos das etapas dos experimentos de acetilação do amido de mandioca reticulado.

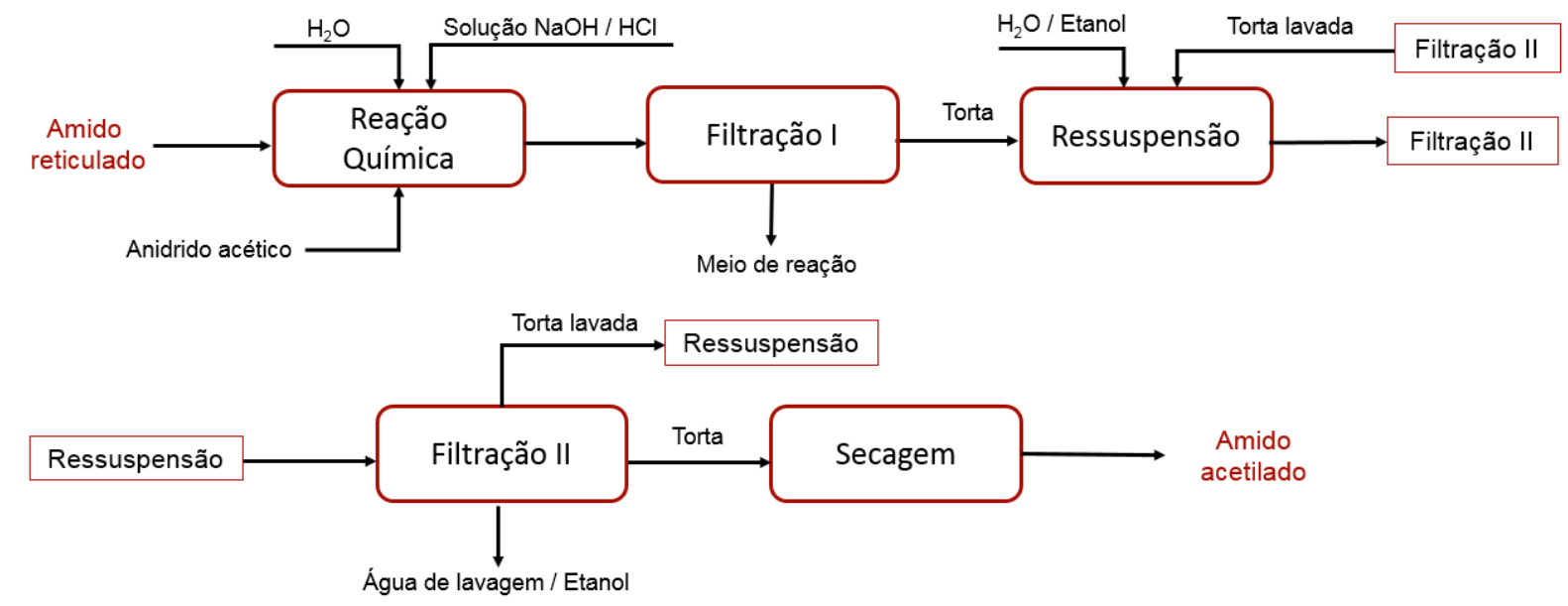

Fonte: Elaborado pela autora (2019).

O tempo total de síntese foi de $4 \mathrm{~h}$, sendo que foram necessárias $2 \mathrm{~h}$ e $15 \mathrm{~min}$ para alimentar $3 \mathrm{~mL}$ de reagente ao sistema de reação. O tempo de processo, englobando as etapas de síntese, de lavagem e de secagem foi de $17 \mathrm{~h}$.

A massa do amido acetilado foi acondicionada protegida da luz e à temperatura ambiente.

Os parâmetros de gelatinização do amido de mandioca acetilado foram determinados em duplicata por meio de curvas microcalorimetria exploratória diferencial, o teor de umidade foi determinado em duplicata de acordo com a norma DIN EN ISO 166:1997 e a estrutura molecular foi avaliada por espectroscopia de absorção no infravermelho e por microscopia Raman. 


\subsection{MÉTODOS}

\subsubsection{Parâmetros de gelatinização do amido de mandioca quimicamente modificado}

A microcalorimetria exploratória diferencial emprega calorímetros de alta sensibilidade e com resolução para medir quantidades pequenas de calor pela imposição de programas de temperatura com taxa de variação igual ou menor que $1,0{ }^{\circ} \mathrm{C} \mathrm{min}^{-1}$ (LEVER et al., 2014).

Outra característica dessa técnica é a quantidade relativamente grande de amostra, quando comparada com a quantidade de amostra de um calorímetro de fluxo de calor convencional, que pode ser testada em cada experimento e que permite acoplar de maneira descontínua outras técnicas à microcalorimetria.

A escolha da microcalorimetria exploratória diferencial foi com base na possibilidade de separar eventos sobrepostos no pico de gelatinização e de acoplar a microscopia Raman. As duas técnicas são complementares e, por meio de princípios diferentes de medida, informam sobre as transições estruturais que as moléculas do amido sofrem na gelatinização e permitem a correlacão direta da presença dos grupos fosfato e acetila com a estabilidade térmica do grânulo.

As curvas de $\mu \mathrm{DSC}$ dos derivados de amido de mandioca foram adquiridas usando o microcalorímetro ( $\mu \mathrm{DSC} 7 \mathrm{Evo}$, Setaram, França) calibrado pelo método do efeito Joule. O naftaleno ( $L G C, \geq 99,97 \mathrm{~mol} / 100 \mathrm{~mol}$, CAS $92-20-3$, Inglaterra) foi usado para verificar a calibração $\left(\Delta_{\text {fus }} H=18,923 \pm 0,083 \mathrm{~kJ} \mathrm{~mol}^{-1}, T_{\text {fus }}=80,25 \pm\right.$ $\left.0,03^{\circ} \mathrm{C}\right)($ RYCERZ, 2013).

Uma célula calorimétrica de Hastelloy C276, com tampa tipo rosca, de capacidade nominal de $1 \mathrm{~cm}^{3}$ foi utilizada nos experimentos; outra célula idêntica vazia foi usada como referência.

O gás nitrogênio a vazão de $80 \mathrm{~mL} \mathrm{~min}{ }^{-1}$ foi utilizado como gás de arraste.

As massas das amostras e da célula calorimétrica foram medidas em uma balança analítica (Shimadzu, AUW22OD, Japão) com resolução de 0,01 mg para a capacidade de $82 \mathrm{~g}$.

Supensões de derivados de amido foram preparadas com água ultrapura tipo III (ASTM, 2018) na razão mássica amido-água de 1:3, considerando a umidade inicial 
das amostras determinada sob temperatura média de $131^{\circ} \mathrm{C}$ e tempo de secagem de 90 min, de acordo com a norma DIN EN ISO 1666:1997.

Uma massa de 30,00 mg de amido foi colocada na célula calorimétrica e água foi adicionada com uma micropipeta. A célula foi fechada e deixada em repouso a $22{ }^{\circ} \mathrm{C}$ por $30 \mathrm{~min}$.

O programa de temperatura aplicado está mostrado na Tabela 5 . Este foi o mesmo que Randzio et al. (2002) aplicaram para examinar a natureza das múltiplas transições endotérmicas $\left(T>80^{\circ} \mathrm{C}\right)$ em sistemas amido de trigo-água, variando o teor de água.

Tabela 5 - Programa de temperatura aplicado nos ensaios de microcalorimetria exploratória diferencial

\begin{tabular}{|c|c|c|c|c|}
\hline \multirow{2}{*}{$\begin{array}{c}\text { Etapa } \\
\text { Descrição }\end{array}$} & \multicolumn{4}{|c|}{ Condições dos ensaios } \\
\hline & $\begin{array}{l}\text { Temperatura inicial } \\
\qquad\left({ }^{\circ} \mathrm{C}\right)\end{array}$ & $\begin{array}{l}\text { Temperatura final } \\
\qquad\left({ }^{\circ} \mathrm{C}\right)\end{array}$ & $\begin{array}{c}\text { Taxa } \\
\left({ }^{\circ} \mathrm{C} \text { min }^{-1}\right)\end{array}$ & $\begin{array}{l}\text { Tempo } \\
\text { (min) }\end{array}$ \\
\hline Equilíbrio & 20,0 & 20,0 & 0 & 5 \\
\hline Aquecimento & 20,0 & 110,0 & 1,0 & 90 \\
\hline Equilíbrio & 110,0 & 110,0 & 0 & 5 \\
\hline Resfriamento & 110,0 & 20,0 & 2,0 & 45 \\
\hline
\end{tabular}

Fonte: Elaborado pela autora (2019).

A taxa de resfriamento de $2,0^{\circ} \mathrm{C} \min ^{-1}$ foi selecionada para diminuir o tempo total do experimento. Essa etapa é uma imposição do instrumento que deve retornar para as condições iniciais.

A técnica de deconvolução foi empregado para estimar os parâmetros de gelatinização e maximizar a resolução do microcalorímetro. $\mathrm{O}$ tratamento dos dados foi realizado no programa Fityk 1.2.9 (WOJDYR, 2010).

A linha de base das curvas de microcalorimetria exploratória diferencial no tempo e na temperatura foram corrigidas por intermédio de splines de interpolação e funções gaussianas (y) foram ajustadas aos dados experimentais, estimando os parâmetros a0, a1 e a2. 


$$
y=a_{0} \exp \left[-\ln (2)\left(\frac{x-a_{1}}{a_{2}}\right)^{2}\right]
$$

Sendo que, an é a altura da função, $a_{1}$ é o centro, a é a meia largura à meia altura, e $x$ é a variável independente. A função soma ponderada dos quadrados residuais foi minimizada usando o método de Levenberg-Marquardt. Na Figura 16, é exemplificada a deconvolução de uma transição exotérmica.

Figura 16 - Exemplo de deconvolução de uma transição exotérmica para uma substância pura.

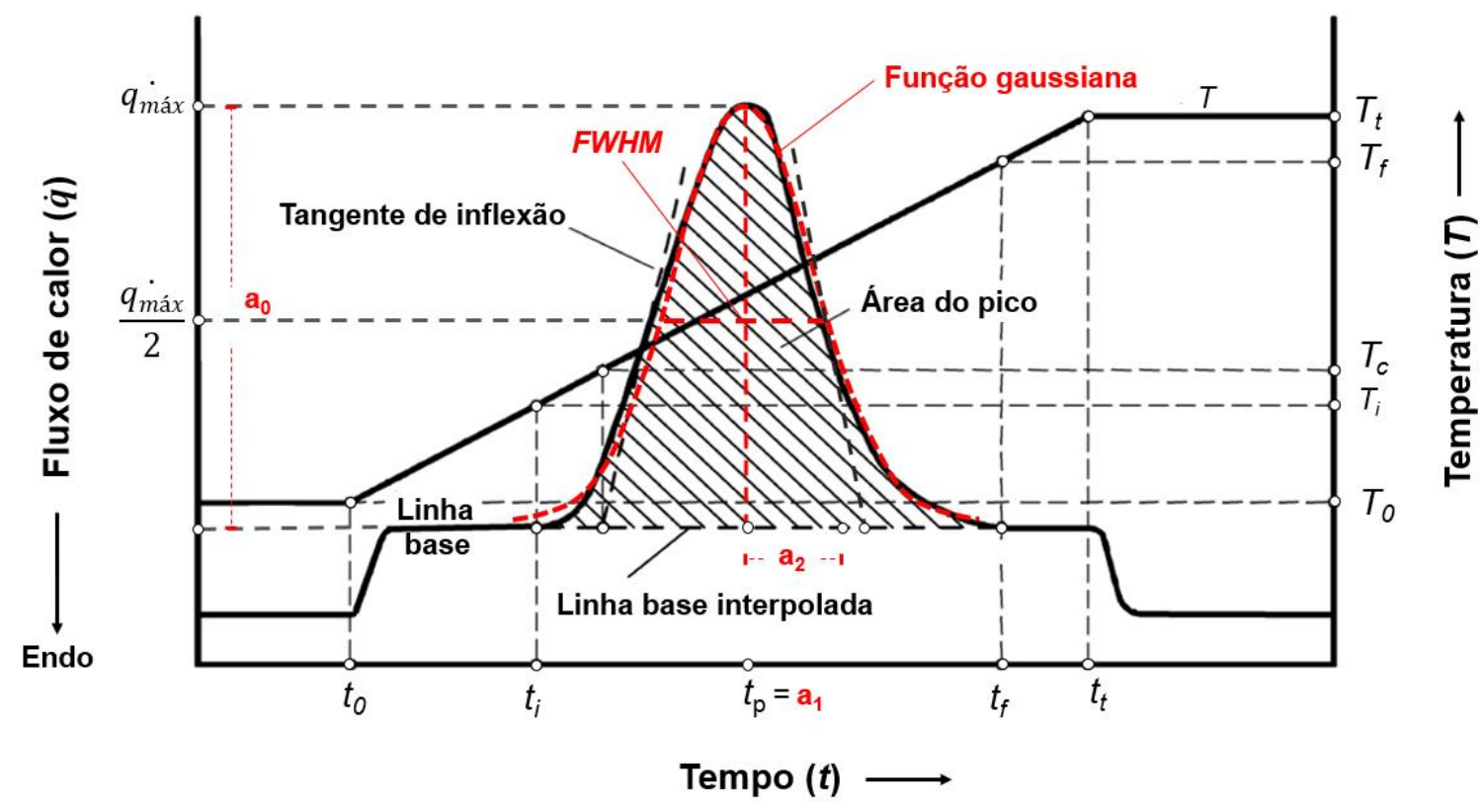

Fonte: Adaptado de Gatta (2006).

$t_{0}$ instante inicial do aquecimento, $t_{\mathrm{i}}$ instante inicial da transição, $t_{f}$ instante final da transição, $t_{\mathrm{p}}$ instante em que ocorre o valor máximo de fluxo de calor, $t_{t}$ instante final do aquecimento, $T_{0}$ temperatura inicial de equilíbrio, $T_{\mathrm{i}}$ temperatura inicial da transição, $T_{\mathrm{f}}$ temperatura final da transição, $T_{\mathrm{t}}$ temperatura final de equilíbrio, $T_{c}$ temperatura do fenômeno para uma substância cristalina, FWHM a largura à meia altura da função gaussiana, ao altura da gaussiana, $a_{1}$ centro da gaussiana que corresponde ao instante em que ocorre o ponto máximo da transição, a2 metade do valor da FWHM e corresponde aos valores extremos de tempo à meia altura da função gaussiana.

A altura da gaussiana ao é a altura do pico da transição $(A)$, ou a intensidade do sinal de fluxo de calor $(\dot{q})$ que corresponde ao valor de máximo ou de mínimo detectado pelo calorímetro. $\mathrm{O}$ valor de $a_{1}$ corresponde ao instante (ou a temperatura 
que é designada de temperatura de pico) no qual o valor de mínimo ou de máximo do sinal é registrado e o valor de a2 corresponde à metade do valor da largura à meia altura $(F W H M)$. O valor de a2 é também proporcional ao desvio padrão $(\sigma)$ da função ajustada:

$$
a_{2}=\sqrt{2 \ln 2} \sigma .
$$

Dessa forma, temperatura de gelatinização $\left(T_{\mathrm{m}}\right)$ corresponde ao valor estimado de $a_{1}$, e a entalpia de gelatinização $\left(\Delta_{\mathrm{m}} H\right)$ corresponde à área da função gaussiana ajustada ao pico da transição na curva fluxo de calor em função do tempo, calculada pela equação:

$$
\Delta_{\mathrm{m}} H=\frac{a_{0} \times F W H M}{2 \sqrt{2 \ln 2} \times 0,3989} .
$$

E para estimar todos os parâmetros da transição pela técnica de deconvolução foi convencionado que a temperatura inicial $\left(T_{\mathrm{m}, \mathrm{i}}\right)$ e final de $\left(T_{\mathrm{m}, \mathrm{f}}\right)$ de gelatinização podem ser estimadas por meio das equações:

$$
T_{\mathrm{m}, \mathrm{i}}=T_{\mathrm{m}}-2 \sigma
$$

e

$$
T_{\mathrm{m}, \mathrm{f}}=T_{\mathrm{m}}+2 \sigma .
$$

Nos programas comerciais de análise de dados de calorimetria exploratória diferencial, a $T_{m, i}$ e $T_{m, f}$ são estimadas passando uma reta tangente pelos pontos de inflexão do pico de fusão, como mostrado na Figura 16 para uma transição exotérmica, e os valores de $T_{\mathrm{m}, \mathrm{i}}$ e $T_{\mathrm{m}, \mathrm{f}}$ correspondem às abscissas desses pontos na curva fluxo de calor em função da temperatura (ASTM; 2015).

Por isso, para a temperatura inicial e final deste trabalho, uma tolerância deve ser admitida para os desvios quando esses valores de temperatura forem comparados com os da literatura.

O tratamento estatístico dos parâmetros de gelatinização foi executado no SPSS (PASW Statistic 17.0, SPSS Inc., Estados Unidos), utilizando métodos de estatística não paramétrica. $O$ teste de Levene não paramétrico foi utilizado para verificar a homogeneidade de variância dos dados (NORDSTOKKE; ZUMBO, 2010). A análise de variância dos dados foi pelo método de Kruskal-Wallis e a comparação entre médias pelo teste de Games-Howell com nível de significância de 0,05. 


\subsubsection{Estrutura molecular do amido de mandioca quimicamente modificado granular}

A espectroscopia de absorção no infravermelho se baseia no movimento vibracional das moléculas provocado por deslocamentos dos núcleos dos átomos (SALA, 2008a). Esses deslocamentos podem ser explicados como se os átomos e as ligações químicas fossem um sistema massa-mola em movimento oscilatório, como ilustrado na Figura 17 (PAVIA et al., 2009; SALA, 2008a).

Figura 17 - Representação de dois sistemas de massas pontuais ligadas por molas executando movimento oscilatório.

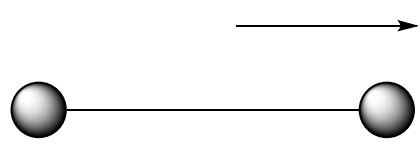

Estiramento

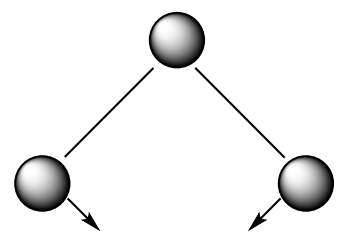

Deformação

Fonte: Adaptado de Sala (2008, p. 26).

De um modo geral, o movimento vibracional é classificado de estiramento ou deformação (Figura 17) . O estiramento ( () ocorre devido a variações no comprimento da ligação química e esses distanceamentos internucleares podem ser simétricos $\left(U_{s}\right)$ ou assimétricos ( $U_{\text {as }}$ ). A deformação ( $\delta$ ) ocorre devido a variações no ângulo da ligação, no plano ou fora do plano molecular, e esses distanciamentos podem também ser simétricos $\left(\delta_{\mathrm{s}}\right)$ ou assimétricos $\left(\delta_{\mathrm{as}}\right)$ (PAVIA et al., 2009; SILVERSTEIN; BASSLER; MORRIL, 1991).

Nas ilustrações mostradas na Figura 18, é possível visualizar os movimentos vibracionais de estiramento e de deformação das ligações químicas do grupo $\left(-\mathrm{CH}_{2}-\right)$. 
Figura 18 - Movimentos vibracionais das ligações químicas do grupo funcional $\left(-\mathrm{CH}_{2}-\right)$.

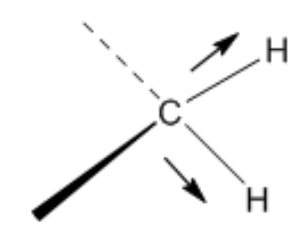

Estiramento simétrico

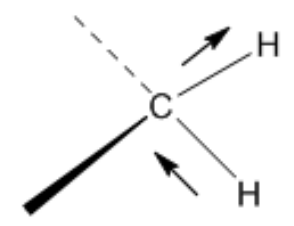

Estiramento assimétrico

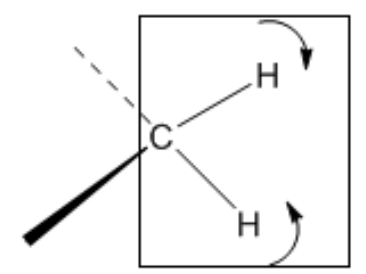

Deformação simétrica no plano

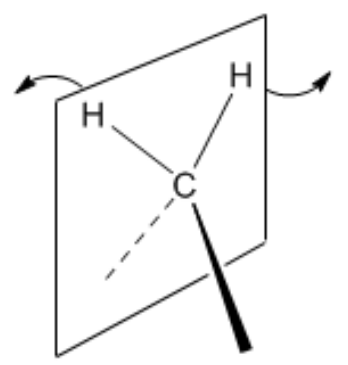

Deformação assimétrica fora do plano

Fonte: Adaptado de Pavia et al. (2009, p.18).

Cada movimento vibracional das ligações de um grupo químico tem uma frequência de vibração que quando coincide com a da luz infravermelha ocorre a absorção. As frequências de vibração dos modos $v_{s}\left(-\mathrm{CH}_{2}-\right)$ e $\mathrm{v}_{\mathrm{as}}\left(-\mathrm{CH}_{2}-\right)$ são em torno de $2853 \mathrm{~cm}^{-1}$ e $2926 \mathrm{~cm}^{-1}$, e a dos modos $\delta_{\mathrm{s}}\left(-\mathrm{CH}_{2}-\right)$ e $\delta_{\text {as }}\left(-\mathrm{CH}_{2}-\right)$ em torno de $1450 \mathrm{~cm}^{-1}$ e $1250 \mathrm{~cm}^{-1}$ (PAVIA et al., 2009).

As moléculas ativas no infravermelho são aquelas cujo momento de dipolo muda quando absorvem a radiação e essa mudança, por sua vez, altera a energia associada ao modo de vibração das ligações químicas. Esta transição de energia e a frequência na qual ocorre são registradas no espectro vibracional (BAKER et al., 2014; PAVIA et al., 2009)

A transmissão, a foto-acústica e a reflectância interna são as técnicas mais empregadas para adquirir espectros vibracionais no infravermelho (ASTM, 2013). Uma característica da técnica de reflectância interna é a baixa profundidade de penetração $\left(D_{p}\right)$ da radiação na amostra, como visualiza-se no desenho esquemático da Figura 19. 
Figura 19 - Representação esquemática do caminho de um raio de luz infravermelha em um elemento de reflectância interna.

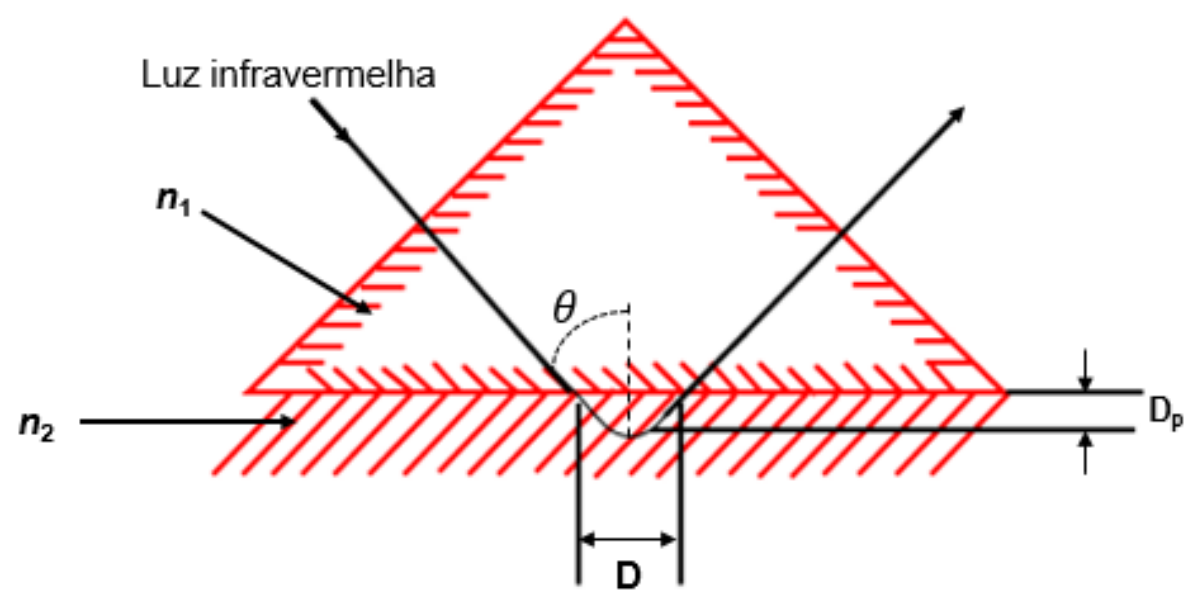

Fonte: Adaptado de ASTM. (2013, p. 2).

$n_{1}$ índice de refração do elemento de reflectância interna; $n_{2}$ índice de refração do material de teste na interface do cristal; $D$ deslocamento do raio; $D_{\mathrm{p}}$ profundidade de penetração; e $\theta$ ângulo de incidência do raio na face interna do cristal.

De acordo com o esquema, a luz atravessa o cristal, incide na sua face interna, ultrapassa seu limite ao refletir e penetra na amostra, deslocando-se. Este deslocamento $(D)$ e a profundidade de penetração delimitam a área da amostra que é analisada.

A espectroscopia de absorção no infravermelho com reflectância interna total atenuada foi utilizada para comprovar a presença dos grupos funcionais fosfato e acetila nas moléculas dos derivados de amido e eventual presença de outros grupos em moléculas que poderiam ter difundido para o interior do grânulo durante o processo de modificação.

Sabendo que o diâmetro médio do grânulo de amido de mandioca varia de 4 a $40 \mu \mathrm{m}$, a distância de penetração da luz infravermelha no grânulo do amido de mandioca foi avaliada por meio da equação 


$$
D_{\mathrm{p}}=\frac{\lambda_{1}}{2 \pi\left(\sin ^{2} \theta-n_{21}\right)^{1 / 2}}
$$

em que $\lambda_{1}=\lambda / n_{1}$ e $n_{21}=n_{2} / n_{1}$. O comprimento de onda $(\lambda)$ da luz infravermelha variou de $2,5 \mu \mathrm{m}\left(4000 \mathrm{~cm}^{-1}\right)$ a $25 \mu \mathrm{m}\left(400 \mathrm{~cm}^{-1}\right) ; n_{1}=1,2$ (valor típico para materiais orgânicos); $n_{2}=2,4$ (cristal de diamante) e $\theta=45^{\circ}$ (ASTM, 2013; CUI et al., 2015; VAMADEVAN; BERTOFT; 2015; WARREN et al., 2013).

Os limites para os valores de profundidade de penetração foram 0,3 e 3,3 $\mu \mathrm{m}$ e correspondem aproximadamente a 1 a $83 \%$ do diâmetro do grânulo do amido de mandioca. As moléculas de amilose e amilopectina sujeitas à modificação química são aquelas localizadas nas regiões amorfas das camadas de crescimento mais externas do grânulo. Assim mesmo com a baixa penetração da luz infravermelha, a área avaliada é representativa da amostra.

Os espectros foram adquiridos no espectrômetro (Alpha, Bruker, Estados Unidos) ao qual foi acoplado o acessório de reflectância total atenuada de reflexão única (Platinum ATR, Bruker, Estados Unidos) de cristal de diamante. O espectro foi adquirido em absorbância com correção de intensidade na região entre 4000 a $400 \mathrm{~cm}^{-1}$, resolução de $2 \mathrm{~cm}^{-1}$ e 60 acumulações.

Amostras de 35,0 mg de amido desidratado foram compactadas (13 mm Die, PerkinElmer, Estados Unidos) sob vácuo com a pressão de compressão próximo de 7,0 atm por 1 min. Para cada amostra três pastilhas foram preparadas e um espectro foi tomado de cada uma.

Os dados foram tratados no Fityk (WOJDYR, 2010). A linha de base foi corrigida por meio do ajuste e da subtração de uma spline de interpolação ao longo da faixa de frequência de 4000 a $800 \mathrm{~cm}^{-1}$. Os espectros com a linha de base corrigida foram normalizados dividindo cada ponto pelo desvio padrão dos valores de absorbância e funções gaussianas foram ajustadas às bandas (ASTM, 2013; ASTM, 2016).

\subsubsection{Estrutura molecular do amido de mandioca quimicamente modificado gelatinizado}

A microscopia Raman se baseia no espalhamento inelástico da luz causado pela interação dos fótons de luz com os modos vibracionais das ligações químicas de 
um material (BUTLER et al., 2016). O esquema mostrado na Figura 20 illustra as formas como a luz espalha ao interagir com um material.

Figura 20 - Esquema identificando os tipos de espalhamento da luz quando um material é irradiado por um laser.

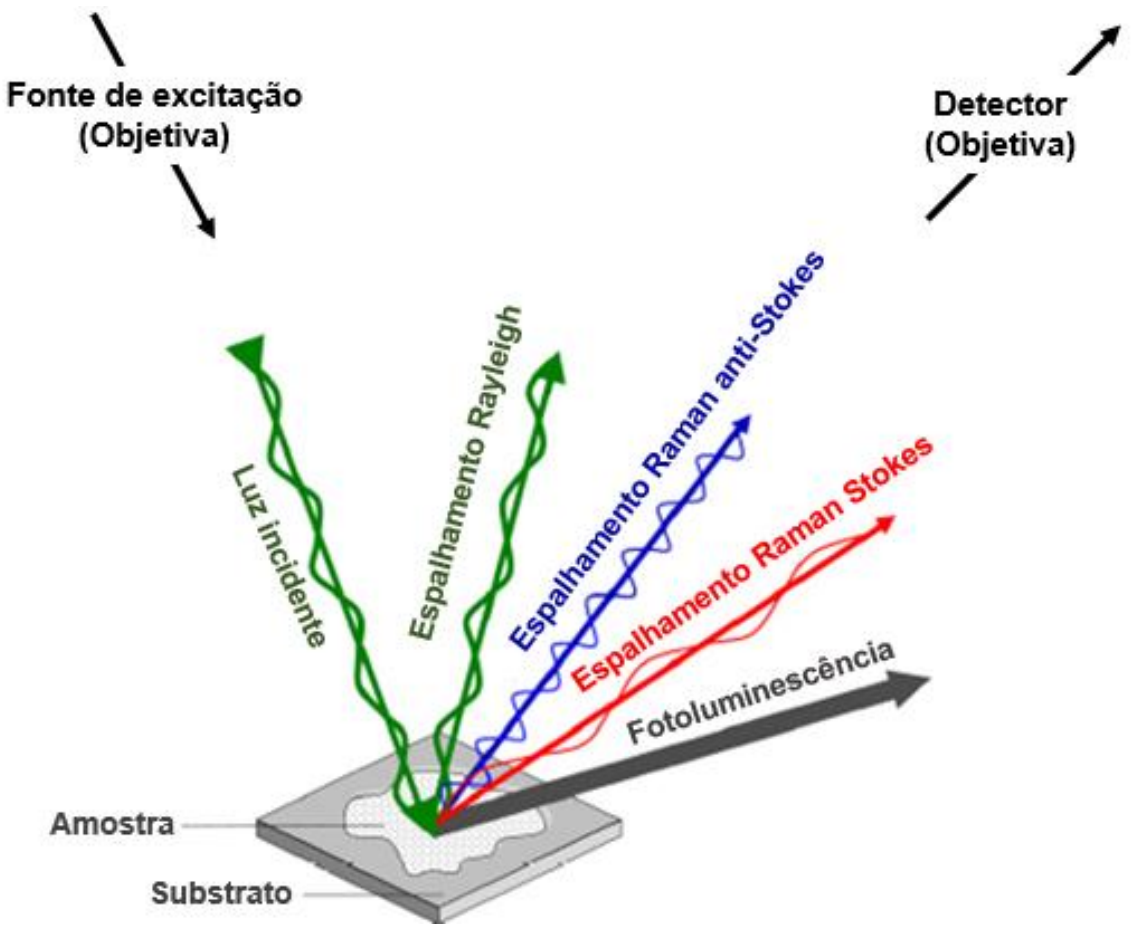

Fonte: Adaptado de Butler et al. (2016).

A interação entre a luz e a matéria pode ser entendida como se fosse uma colisão entre esferas. Estas seriam os fótons da luz incidente e os elétrons da nuvem eletrônica das ligações químicas, a interação ocorre quando os fótons colidem com os elétrons e o resultado da colisão dependerá do estado vibracional das ligações químicas dos grupos funcionais presentes na molécula do material (SALA, 2008b; BUTLER et al., 2016).

Na colisão elástica ou Rayleigh, os fótons mudam de direção e espalham com a mesma energia que incidiram no material. Transferência de energia ocorre na colisão inelástica ou Raman. Se a energia for transferida dos fótons para os elétrons, os fótons espalharão com menor energia (Stokes) e, no caso contrário, eles espalharão com maior energia (anti-Stokes) (SALA, 2008b; BUTLER et al., 2016).

Nos dois casos, o espalhamento da luz é acompanhado por transições de energia nos modos vibracionais (BUTLER et al., 2016). Isto ocorre porque o campo 
elétrico da luz incidente movimenta os elétrons na nuvem eletrônica da molécula e um momento de dipolo induzido é formado, o qual interage com as ligações da molécula, polarizando a nuvem eletrônica. A polarizabilidade da molécula revela as variações de energia sofridas pelos modos vibracionas das ligações químicas (SALA, 2008b).

O esquema da Figura 20 mostra também o fenômeno da fotoluminescência, inerente ao espalhamento da luz, no qual um elétron eventualmente excitado muda de nível eletrônico e ao relaxar emite um fóton, o qual é coletado junto com os fótons espalhados da luz. Essa é uma das causas do ruído de fundo nos espectros Raman (BUTLER et al., 2016).

A microscopia Raman foi escolhida para avaliar a influência dos grupos funcionais fosfato e acetila sobre as transições estruturais sofridas pelas moléculas do amido nos experimentos de microcalorimetria exploratória diferencial.

A molécula de água pouco se polariza e a intensidade do espalhamento Raman é baixa, a ponto de não interferir no espectro o que é uma vantagem quando se deseja informações estruturais das moléculas gelatinizadas do amido (BUTLER et al., 2016).

Os espectros do amido de mandioca reticulado e acetilado foram adquiridos em um microespectrômetro Raman (InVia, Renishaw, Reino Unido) com microscópio óptico (DM 2500M, Leica Biosystemns, Alemanha) e detector charge coupled device. O laser de $\lambda=785 \mathrm{~nm}$ (HPNIR785, Renisahw, Reino Unido), cujo comprimento de onda foi corrigido tomando o espectro do cristal de silício, foi utilizado para irradiar as amostras.

Uma lente objetiva de longo alcance com magnificação de 20x, abertura numérica de 0,40 e distância focal de $180 \mathrm{~mm}$ foi utilizada para focalizar a luz na amostra e coletar a luz espalhada. $O$ instrumento foi configurado para o modo padrão com rede de difração de 1200 linhas por milímetro. Os parâmetros de aquisição dos espectros foram tempo de exposição à luz de 1 s, potência do laser de 100\%, faixa de frequência de 3200 a $400 \mathrm{~cm}^{-1}$, resolução de $0,5 \mathrm{~cm}^{-1}$ com três acumulações.

Os espectros foram adquiridos das amostras gelatinizadas nos ensaios microcalorimetria exploratória diferencial. Placas de Petri de poliestireno cristal foram usadas como substrato.

Os dados foram tratados no $\operatorname{MATLAB}^{\circledR}$ (R2018a, Mathworks, Estados Unidos). O ruído de fundo foi removido no aplicativo Biodata e os espectros foram normalizados dividindo cada um pelo desvio padrão dos valores de intensidade Raman (BUTLER et al., 2016; ZHAO et al., 2007). 


\section{RESULTADOS}

\subsection{SIINTESE DO AMIDO DE MANDIOCA QUIMICAMENTE MODIFICADO}

Na unidade química automatizada construída no laboratório, os experimentos de síntese do amido de mandioca reticulado e acetilado foram adequadamente conduzidos sob pH controlado. As curvas de variação do $\mathrm{pH}$ mostraram que não houve mudança do $\mathrm{pH}$ do meio de reticulação e o sistema de controle permaneceu inoperante ao longo do tempo. Diferentemente, o sistema de controle atuou e manteve o pH do meio de acetilação alcalino na faixa pretendida de 8,0 a 8,5.

A ordem de execução dos experimentos de síntese dos derivados reticulados de amido de mandioca e as condições do meio de reticulação estão apresentadas na Tabela 6.

Tabela 6 (continua) - Ordem randomizada de execução dos experimentos de síntese dos do amido de mandioca reticulado, com as respectivas condições de $\mathrm{pH}$, temperatura e razão molar de trimetafosfato trisódio (STMP) por unidade de anidroglicose (AGU) do meio de reticulação

\begin{tabular}{|c|c|c|c|c|}
\hline \multicolumn{2}{|c|}{ Experimento } & \multicolumn{3}{|c|}{ Condições do meio de reticulação(1,2) } \\
\hline Ordem & Derivado & $\mathrm{pH}$ & Temperatura $\left({ }^{\circ} \mathrm{C}\right)$ & RSTMP:AGU \\
\hline $1^{\circ}$ & $\mathrm{R}_{9}$ & $9,8 \pm 0,0$ & $51,8 \pm 1,0$ & 0,026 \\
\hline $2^{\circ}$ & $\mathrm{R}_{2}$ & $10,9 \pm 0,0$ & $51,7 \pm 0,4$ & 0,026 \\
\hline $3^{\circ}$ & $\mathrm{R}_{10}$ & $10,9 \pm 0,1$ & $51,1 \pm 1,2$ & 0,027 \\
\hline $4^{\circ}$ & $\mathrm{R}_{1}$ & $9,9 \pm 0,0$ & $51,6 \pm 0,2$ & 0,026 \\
\hline $5^{\circ}$ & $\mathrm{R}_{15}$ & $9,8 \pm 0,0$ & $51,7 \pm 0,2$ & 0,079 \\
\hline $6^{\circ}$ & $\mathrm{R}_{16}$ & $10,8 \pm 0,1$ & $51,6 \pm 0,8$ & 0,077 \\
\hline $7^{0}$ & $\mathrm{R}_{4}$ & $11,0 \pm 0,0$ & $51,4 \pm 0,6$ & 0,076 \\
\hline $8^{\circ}$ & $\mathrm{R}_{13}$ & $10,0 \pm 0,0$ & $51,4 \pm 0,3$ & 0,026 \\
\hline
\end{tabular}


Tabela 6 (conclusão) - Ordem randomizada de execução dos experimentos de síntese dos do amido de mandioca reticulado, com as respectivas condições de $\mathrm{pH}$, temperatura e razão molar de trimetafosfato trisódio (STMP) por unidade de anidroglicose (AGU) do meio de reticulação

\begin{tabular}{|c|c|c|c|c|}
\hline \multicolumn{2}{|c|}{ Experimento } & \multicolumn{3}{|c|}{ Condições do meio de reticulação(1) } \\
\hline Ordem & Derivado & $\mathrm{pH}$ & Temperatura $\left({ }^{\circ} \mathrm{C}\right)$ & $R_{\text {STMP:AGU }}$ \\
\hline $9^{\circ}$ & $\mathrm{R}_{5}$ & $10,0 \pm 0,0$ & $51,6 \pm 0,3$ & 0,026 \\
\hline $10^{\circ}$ & $\mathrm{R}_{14}$ & $11,1 \pm 0,1$ & $51,1 \pm 0,2$ & 0,027 \\
\hline $11^{\circ}$ & $\mathrm{R}_{11}$ & $10,0 \pm 0,0$ & $51,2 \pm 0,8$ & 0,076 \\
\hline $12^{\circ}$ & $\mathrm{R}_{7}$ & $10,0 \pm 0,0$ & $51,3 \pm 0,5$ & 0,076 \\
\hline $13^{\circ}$ & $\mathrm{R}_{8}$ & $11,0 \pm 0,0$ & $51,6 \pm 0,3$ & 0,076 \\
\hline $14^{\circ}$ & $\mathrm{R}_{12}$ & - & - & - \\
\hline $15^{\circ}$ & $\mathrm{R}_{6}$ & - & - & - \\
\hline $16^{\circ}$ & $\mathrm{R}_{3}$ & - & - & - \\
\hline
\end{tabular}

Fonte: Elaborado pela autora (2019).

(1) Média \pm Desvio Padrão, se aplicável.

(2) O tempo de reação na síntese dos derivados reticulados foi $5 \mathrm{~h}$.

A ordem randomizada de execução dos experimentos foi respeitada, mas interrompida no $13^{\circ}$ experimento porque não foi possível recuperar os derivados $R_{4}$, $R_{8}$ e $R_{16}$, em uma das etapas de filtração na lavagem.

Os experimentos de síntese de $\mathrm{R}_{4}$ e $\mathrm{R}_{16}$ foram repetidos para descartar a possibilidade de erro experimental e as condições do meio de reticulação do segundo experimento de síntese de $\mathrm{R}_{4}$ e $\mathrm{R}_{16}$ são as mostradas na Tabela 6 .

A variação do $\mathrm{pH}$ ao longo do tempo de reação pode ser visualizada na Figura 21, referente à síntese de $R_{1}$. 
Figura 21 - Variação do pH (a) e da temperatura (b) do meio de reticulação em função do tempo de síntese do derivado reticulado $\mathrm{R}_{1}\left(\mathrm{pH} 10,0\right.$ e $\left.R_{\text {StMP:AGU }} 0,03\right)$.

(a)

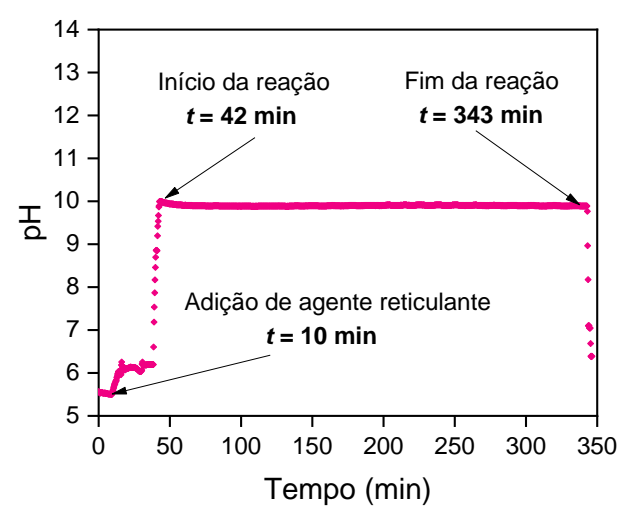

(b)

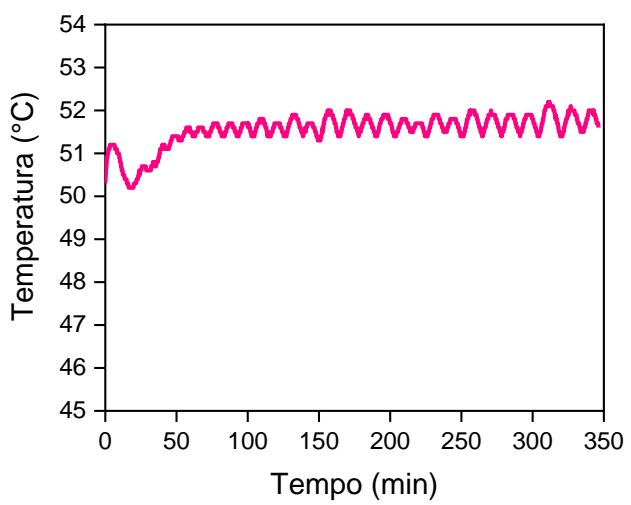

Fonte: Elaborado pela autora (2019).

Como pode ser observado na Figura 21, o pH inicial do meio de reticulação estava ácido, mesmo após a adição do trimetafosfato trisódio e, depois, foi alcalinizado para dar início a reação. Observa-se também que o $\mathrm{pH}$ permaneceu constante, o sistema de controle não atuou e a temperatura foi próximo de $51^{\circ} \mathrm{C}$ ao longo do tempo de reação.

A variação do $\mathrm{pH}$ ao longo do tempo de reação de síntese dos demais derivados apresentou perfil semelhante ao de $R_{1}$, com a temperatura de reação constante em $\pm 51{ }^{\circ} \mathrm{C}$ nas quatro condições de reação. As curvas da Figura 22 mostram a variação do $\mathrm{pH}$ e da temperatura do meio de reticulação de $\mathrm{R}_{4}$.

Figura 22 - Variação do pH (a) e da temperatura (b) do meio de reticulação em função do tempo de síntese do derivado reticulado $\mathrm{R}_{4}\left(\mathrm{pH} 11,0\right.$ e $\left.R_{\text {StMP:AGU }} 0,08\right)$.

(a)

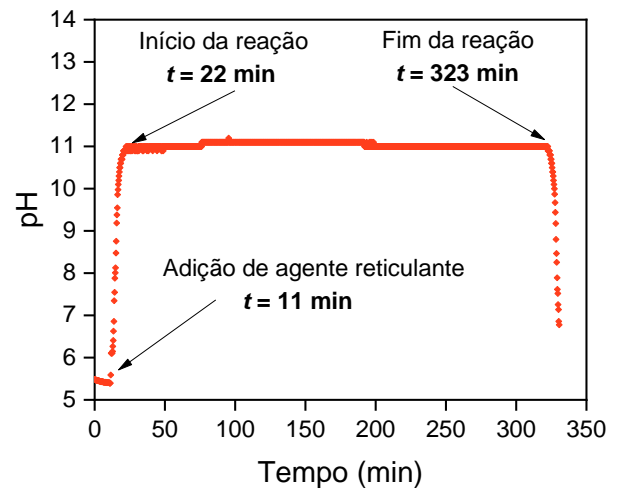

(b)

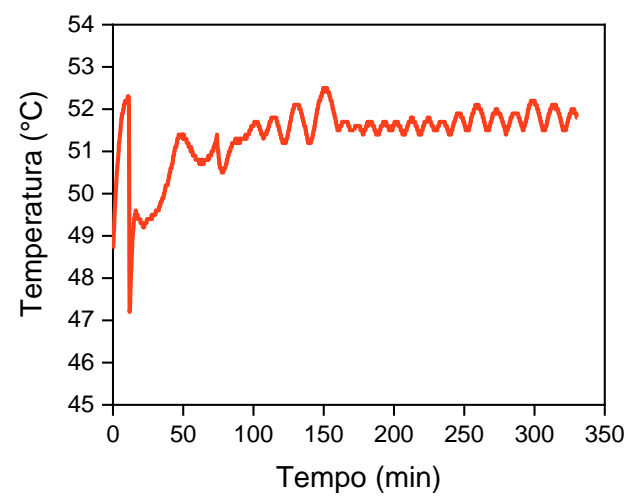

Fonte: Elaborado pela autora (2019). 
Observa-se na Figura 22 que houve oscilações no pH do meio de reação ao longo do tempo, mas essas alterações não necessitaram de ação do sistema de controle, e que a temperatura permaneceu em torno de $\pm 51^{\circ} \mathrm{C}$. Na Figura 23, estão mostradas as curvas de variação do $\mathrm{pH}$ e da temperatura do longo do tempo do segundo experimento do derivado $\mathrm{R}_{16}$.

Figura 23 - Variação do pH (a) e da temperatura (b) do meio de reticulação em função do tempo de síntese do derivado reticulado $R_{16}\left(\mathrm{pH} 11,0\right.$ e $R_{\text {StMP:AGU }} 0,08$ ).

(a)

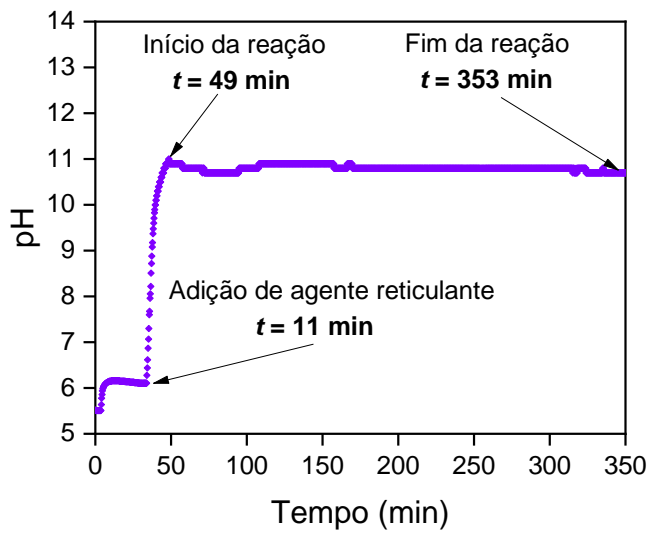

(b)

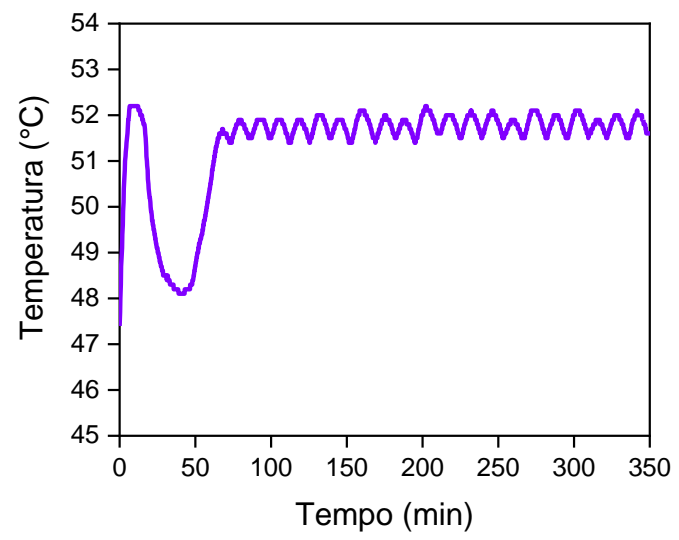

Fonte: Elaborado pela autora (2019).

Como pode ser visualizado na Figura 23 , oscilações do pH ocorreram no início da reação,contudo essas oscilações também não precisaram de ação do sistema de controle do $\mathrm{pH}$.

Nos experimentos de síntese em que o amido de mandioca foi reticulado no $\mathrm{pH}$ 11,0 e razão molar de trimetafosfato trisódio por unidade de anidroglicose de 0,08 , os derivados não foram recuperados após lavagem porque não foi possível sua filtração, a exceção foi $R_{16}$

As curvas de variação do $\mathrm{pH}$ do meio de reticulação mostraram que o $\mathrm{pH}$ não variou ao longo do tempo de reação o que indicou que a reação de reticulação das moléculas do amido de mandioca com trimetafosfato trisódio foi lenta ou não ocorreu nas condições de processo estudadas. 
Os valores do $\mathrm{pH}$ e da temperatura do meio de reação medidos durante a síntese do amido de mandioca acetilado estão mostrados na Tabela 7.

Tabela 7 - Valores medidos de temperatura e pH (Média \pm Desvio Padrão) do meio de acetilação dos experimentos de síntese dos derivados acetilados de amido de mandioca

\begin{tabular}{lcc}
\hline & \multicolumn{2}{c}{ Condições do meio de acetilção ${ }^{(1)}$} \\
\cline { 2 - 3 } Derivado & Temperatura $\left({ }^{\circ} \mathrm{C}\right)$ & $\mathrm{pH}$ \\
\hline $\mathrm{RA}_{1}$ & $31,3 \pm 1,2$ & $8,4 \pm 0,2$ \\
$\mathrm{RA}_{2}$ & $31,4 \pm 1,0$ & $8,3 \pm 0,2$ \\
$\mathrm{RA}$ & $31,7 \pm 0,8$ & $8,4 \pm 0,3$ \\
$\mathrm{RA}$ & $31,7 \pm 0,7$ & $8,4 \pm 0,2$ \\
$\mathrm{RA}_{9}$ & $30,9 \pm 0,7$ & $8,5 \pm 0,3$ \\
$\mathrm{RA}_{10}$ & $31,2 \pm 0,7$ & $8,4 \pm 0,2$ \\
$\mathrm{RA}_{11}$ & $31,3 \pm 1,3$ & $8,4 \pm 0,3$ \\
$\mathrm{RA}_{13}$ & $31,1 \pm 0,6$ & $8,4 \pm 0,3$ \\
$\mathrm{RA}_{14}$ & $30,8 \pm 1,4$ & $8,4 \pm 0,3$ \\
$\mathrm{RA}_{15}$ & $30,6 \pm 0,9$ & $8,3 \pm 0,3$ \\
$\mathrm{RA}_{16}$ & $31,6 \pm 1,0$ & $8,5 \pm 0,4$
\end{tabular}

Fonte: Elaborado pela autora (2019).

(1) Os derivados foram acetilados na mesma razão molar de anidrido acético por unidade de anidroglicose de 0,16 e tempo de reação de $2,5 \mathrm{~h}$.

A variação do $\mathrm{pH}$ do meio de acetilação ao longo da síntese de $\mathrm{RA}_{1}$ é mostrada na Figura 24, em que o primeiro patamar corresponde à etapa de hidratação e inchamento reversível das moléculas do amido nas regiões amorfas do grânulo e o segundo patamar corresponde à adição do anidrido acético. 
Figura 24 - Variação do pH (a) e da temperatura (b) do meio de acetilação em função do tempo de síntese do derivado acetilado $\mathrm{RA}_{1}\left(\mathrm{pH} 10,0\right.$ e $\left.R_{\text {StMP:AGU }} 0,03\right)$.

(a)

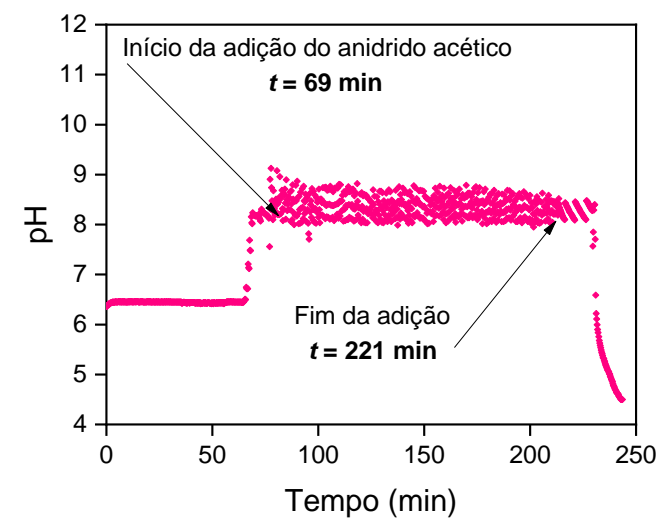

(b)

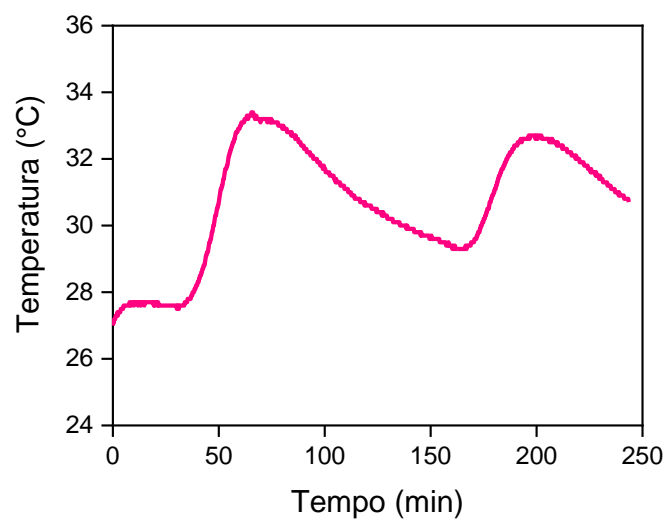

Fonte: Elaborado pela autora (2019).

Como observa-se na Figura 24, o pH do meio de acetilação permaneceu alcalino durante a adição do anidrido acético, indicando que o controle automático do sistema atuou adequadamente. Já a curva de variação de temperatura ao longo do tempo mostrou que a temperatura do meio de acetilação não atingiu o regime permanente. Isto ocorreu porque a temperatura de $30^{\circ} \mathrm{C}$ foi próxima da temperatura ambiente. $O$ sistema elétrico de aquecimento do banho de água não conseguiu manter a temperatura, que variou entre 25 e $35^{\circ} \mathrm{C}$.

A variação do $\mathrm{pH}$ do meio de acetilação dos outros experimentos de síntese apresentou perfil semelhante ao de $R A_{1}$ e com a temperatura variando entre 25 e $35^{\circ} \mathrm{C}$, como mostra a Figura 25, referente ao experimento de síntese de $R A_{2}$.

Figura 25 - Variação do pH (a) e da temperatura (b) do meio de acetilação em função do tempo de síntese do derivado acetilado $\mathrm{RA}_{2}$ (pH 11,0 e $R_{\text {StMP:AGU }} 0,03$ ).

(a)

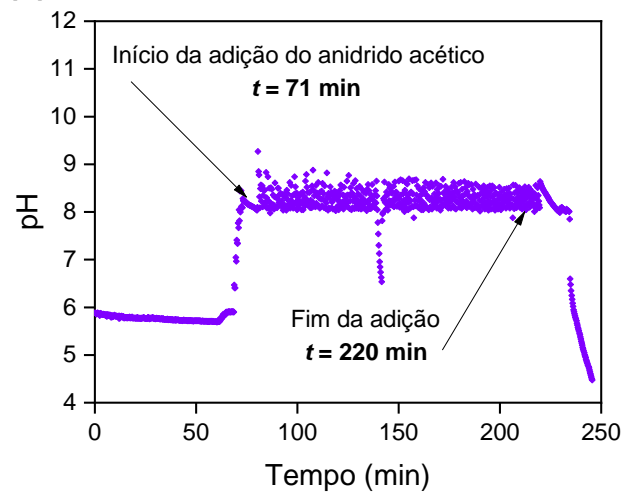

(b)

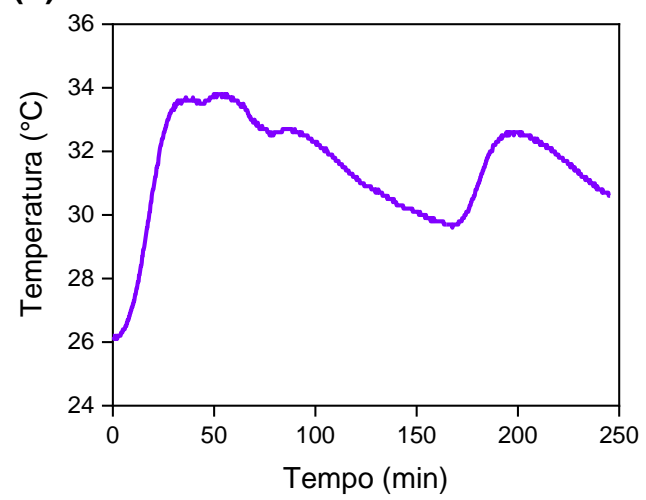

Fonte: Elaborado pela autora (2019). 
Como pode ser visualizado na curva de variação do pH ao longo do tempo da Figura 25, o pH do meio de acetilação de RA2 atingiu valores instantâneos entre 6,0 e 9,0. Dentre os experimentos de síntese dos derivados acetilados, o menor valor de $\mathrm{pH}$ registrado foi próximo de 6,0 (Figura 25) e o maior valor de $\mathrm{pH}$ registrado foi próximo de 11,0, como visualiza-se na Figura 26, referente ao experimento de síntese de $R_{15}$.

Figura 26 - Variação do pH (a) e da temperatura (b) do meio de acetilação em função do tempo de síntese do derivado acetilado $\mathrm{RA}_{15}\left(\mathrm{pH} 10,0\right.$ e $\left.R_{\text {StMP:AGU }} 0,08\right)$.

(a)

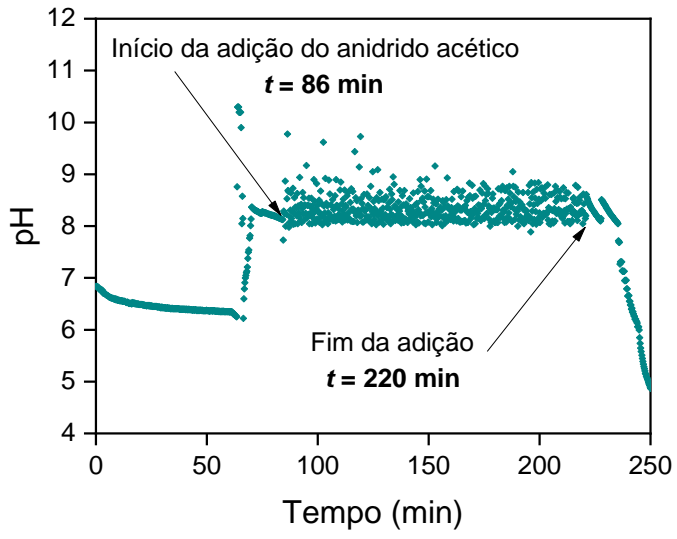

(b)

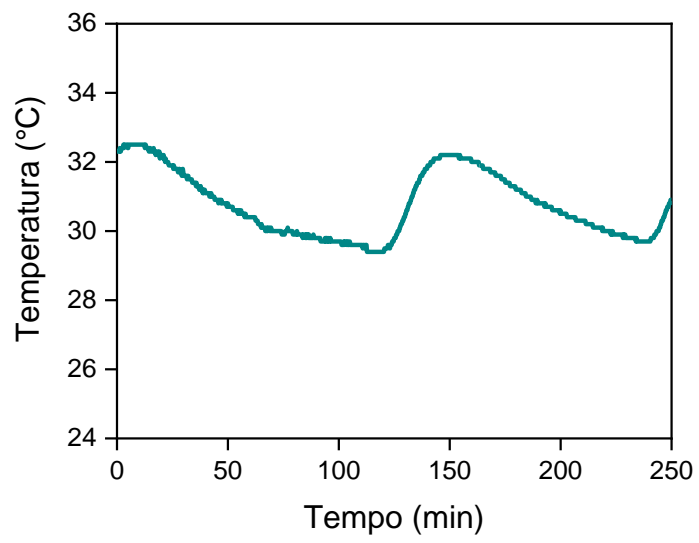

Fonte: Elaborado pela autora (2019).

A curva de variação do $\mathrm{pH}$ do meio de acetilação do derivado $\mathrm{RA}_{15}$ foi a que apresentou os maiores valores de $\mathrm{pH}$ instantâneos. De qualquer forma, o meio de acetilação permaneceu a maior parte do tempo na faixa desejada de 8,0 a 8,5 e sem risco de gelatinizar o amido de mandioca por excesso de $\mathrm{NaOH}(\mathrm{aq})$.

Esses resultados mostraram que os derivados acetilados de amido de mandioca foram sintetizados sob condições semelhantes de reação e seguras para o grânulo de amido de mandioca.

\subsection{ESTRUTURA MOLECULAR DO AMIDO DE MANDIOCA QUIMICAMENTE MODIFICADO GRANULAR}

Os resultados da análise dos espectros no infravermelho dos grânulos do amido de mandioca reticulado nas quatro condições de reação não mostraram a 
presença de novas ligações químicas. Já os resultados do amido de mandioca acetilado mostraram a presença de ligações associadas com a formação de acetato de amido.

Os espectros normalizados de absorção no infravermelho do amido de mandioca nativo e dos derivados reticulados podem ser visualizados na Figura 27 , indicando que não houve alteração no espectro vibracional dos derivados reticulados em relação ao espectro do amido de mandioca nativo nas quatro condições de reação estudadas.

Figura 27 - Espectros normalizados de absorção no infravermelho do (a) amido de mandioca nativo e dos derivados reticulados a pH 10,0 e $R_{\text {STMP:AGU }}$ 0,03, e dos (b) derivados reticulados a pH 11,0 e $R_{\text {STMP:AGU }} 0,03$, e dos derivados (c) reticulados a pH 10,0 e $R_{\text {STMP:AGU }}$ 0,08, e do (d) derivado reticulado a pH 11,0 e $R_{\text {STMP:AGU }} 0,08$.

(a)

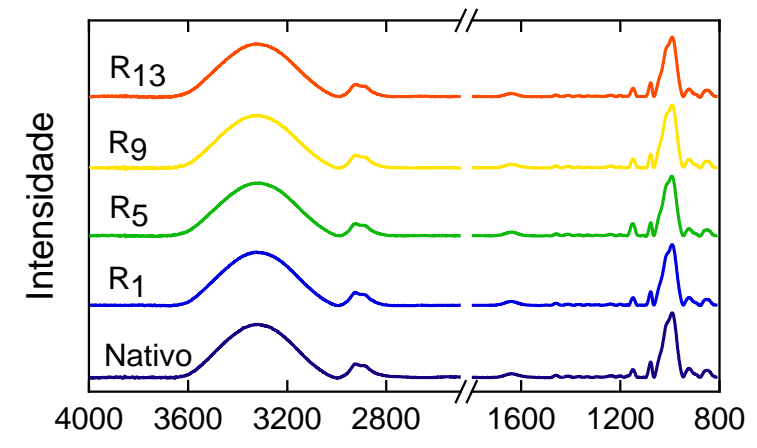

(c)

Número de onda $\left(\mathrm{cm}^{-1}\right)$

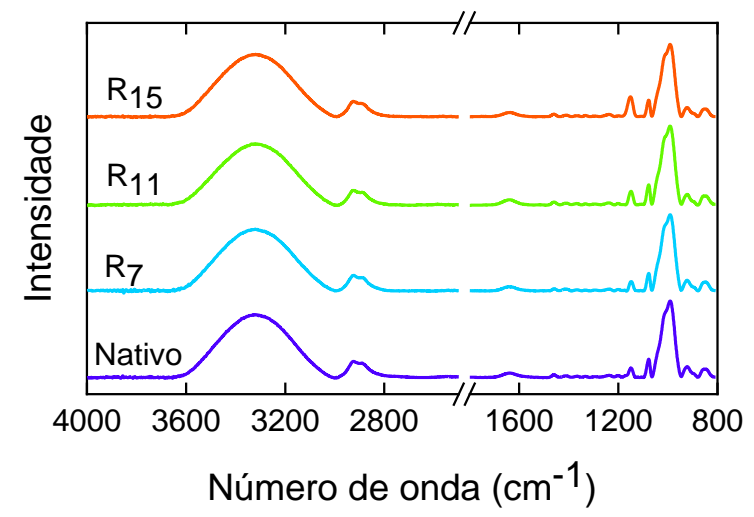

(b)

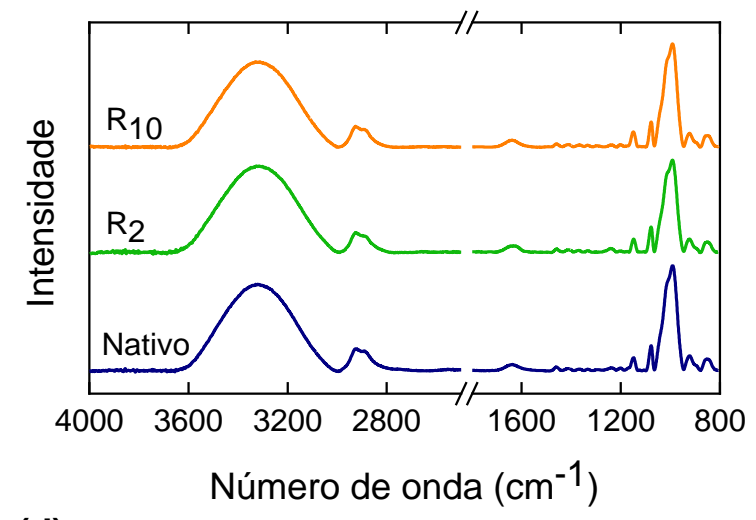

(d)

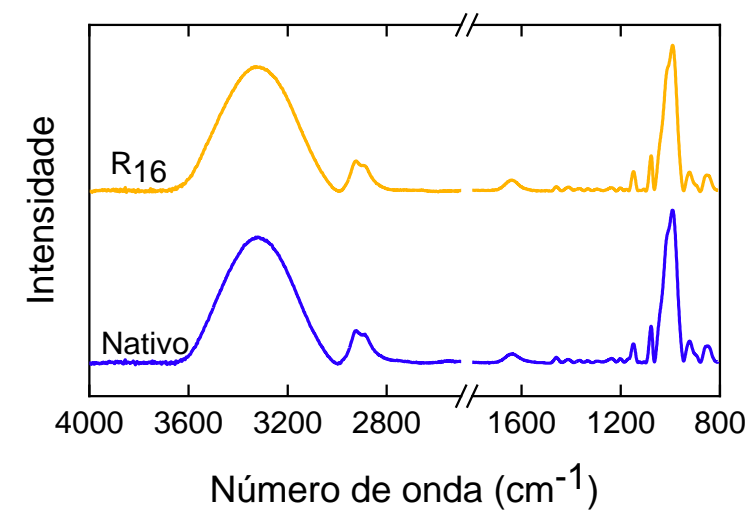

Fonte: Elaborado pela autora (2019).

Os modos vibracionais de deformação axial (סaxial) das ligações no grupo fosfato $(\mathrm{P}=\mathrm{O})$ e $(\mathrm{C}-\mathrm{P}-\mathrm{O})$ absorvem radiação infravermelha nas faixas de frequência de 1300 a $1250 \mathrm{~cm}^{-1}, 1050$ a $940 \mathrm{~cm}^{-1}$ e 830 a $740 \mathrm{~cm}^{-1}$ (SILVERSTEIN; 
BASSLER; MORRIL, 1974; SILVERSTEIN; BASSLER; MORRIL, 1991). Os espectros de absorção no infravermelho do amido de mandioca nativo e do derivado $R_{1}(\mathrm{pH} 10,0$ e RStMP:AGU 0,03) deconvoluídos nessas faixas de frequência estão mostrados na Figura 28.

Figura 28 - Comparação dos espectros deconvoluídos de absorção no infravermelho do amido de mandioca nativo nas faixas de frequência de (a) 1500 a $1100 \mathrm{~cm}^{-1}$, de (b) $1120 \mathrm{a}$ 940) $\mathrm{cm}^{-1}$ e de (c) 940 a $820 \mathrm{~cm}^{-1}$ e do derivado $\mathrm{R}_{1}\left(\mathrm{pH} 10,0\right.$ e $R_{\text {STMP:AGU }} 0,03$ ) nas faixas de frequência de (d) 1500 a $1100 \mathrm{~cm}^{-1}$, de (e) 1120 a $940 \mathrm{~cm}^{-1}$ e de (f) 940 a $820 \mathrm{~cm}^{-1}$.

(a)

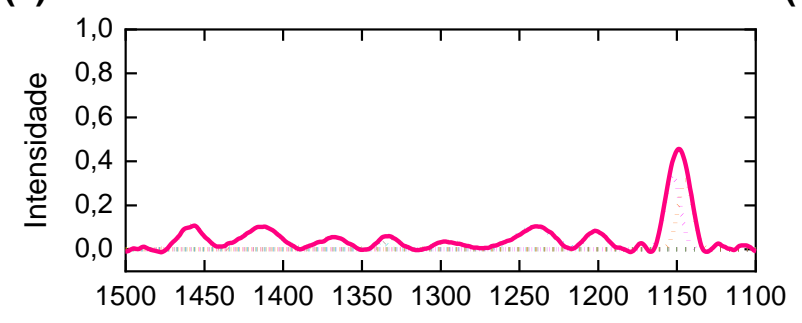

(b)

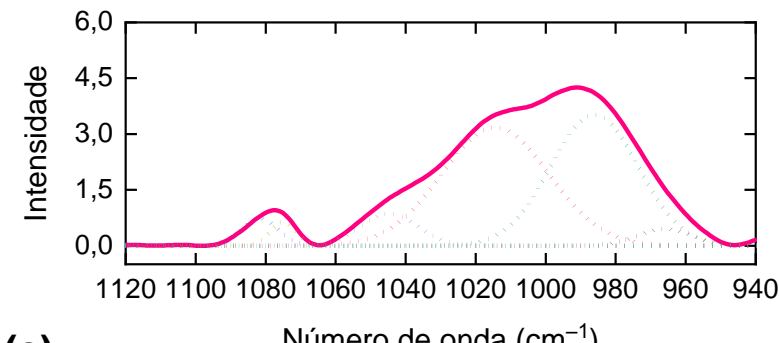

(c)

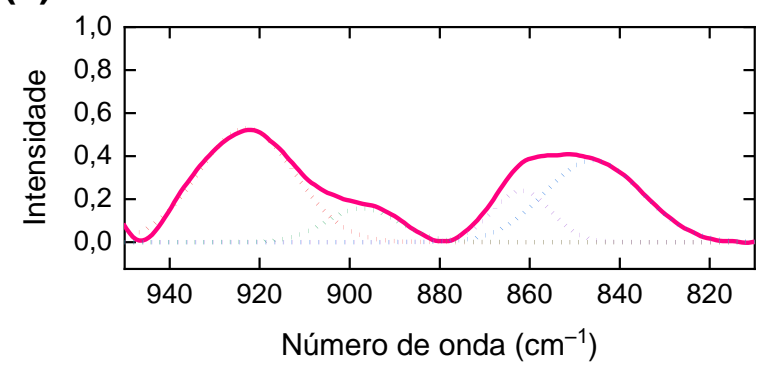

(d)

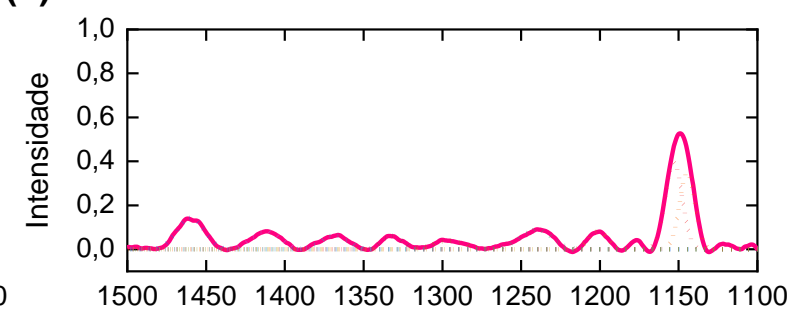

(e)
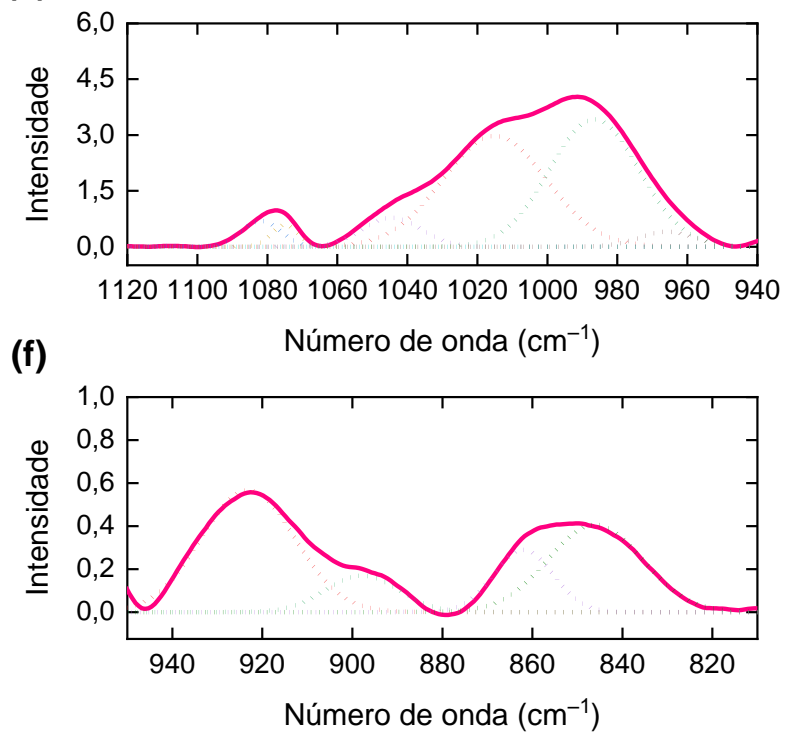

Fonte: Elaborado pela autora (2019).

Observa-se na Figura 28 que o espectro deconvoluído de $\mathrm{R}_{1}$ na frequência de 1500 a $1100 \mathrm{~cm}^{-1}$ não revelou banda associada com o modo vibracional de $\delta_{\text {axial }}(\mathrm{P}=0$ ) e os espectros deconvoluídos nas faixas de frequência de $1120 \mathrm{a}$ $940 \mathrm{~cm}^{-1}$ e de 940 a $820 \mathrm{~cm}^{-1}$ também não revelaram bandas associadas com o modo vibracional de $\delta_{\text {axial }}(\mathrm{C}-\mathrm{P}-\mathrm{O})$. 
Semelhantemente, os espectros de absorção no infravermelho de $R_{16}(\mathrm{pH} 11,0$ e RSTMP:AGU 0,08) deconvoluídos na região de 1500 a $820 \mathrm{~cm}^{-1}$ também não indicaram bandas associadas com os modos vibracionais das ligações no grupo fosfato, como pode ser visualizado na Figura 29.

Figura 29 - Comparação dos espectros deconvoluídos de absorção no infravermelho do amido de mandioca nativo nas faixas de frequência de (a) 1500 a $1100 \mathrm{~cm}^{-1}$, de (b) 1120 a $940 \mathrm{~cm}^{-1}$ e de (c) 940 a $820 \mathrm{~cm}^{-1}$ e do derivado $\mathrm{R}_{16}\left(\mathrm{pH} 11,0\right.$ e $\left.R_{\text {StMP:AGU }} 0,08\right)$ nas faixas de frequência de (d) 1500 a $1100 \mathrm{~cm}^{-1}$, de (e) 1120 a $940 \mathrm{~cm}^{-1}$ e de (f) $940 \mathrm{a}$ $820 \mathrm{~cm}^{-1}$.

(a)

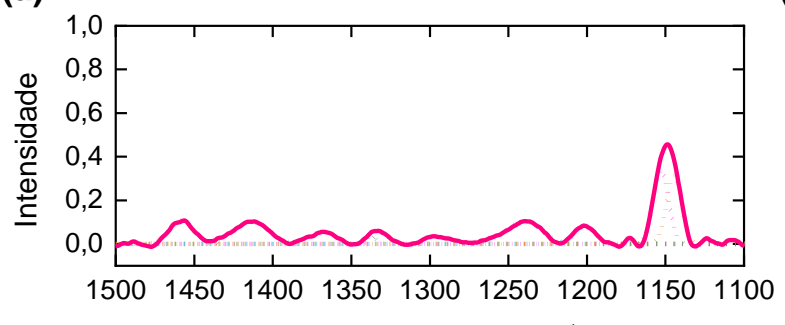

(b)

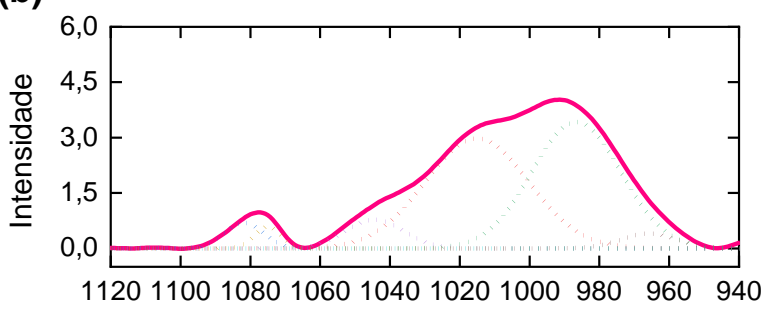

(c)

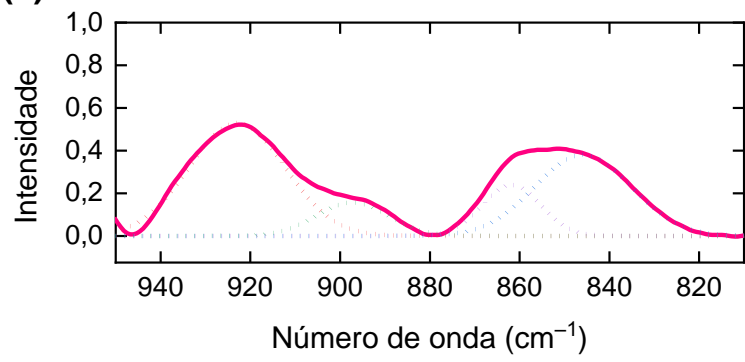

(d)

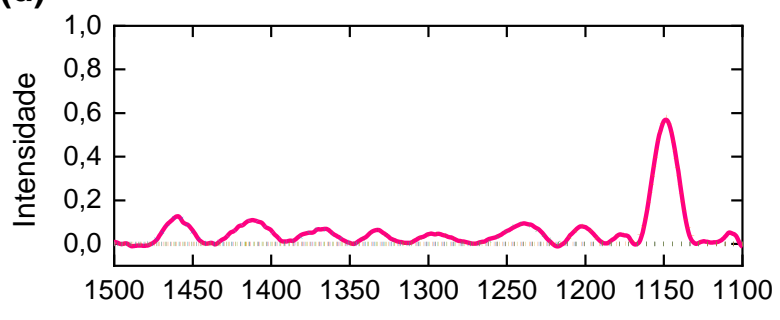

(e)

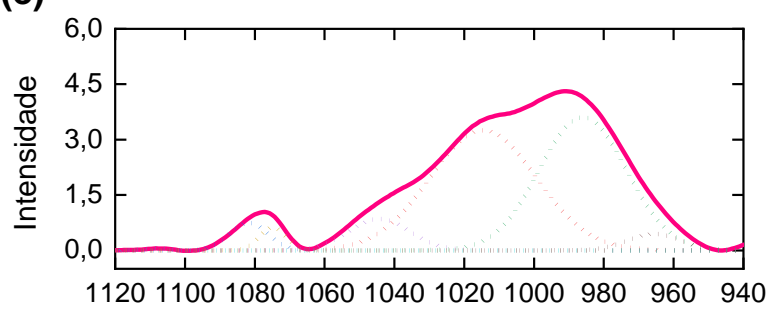

(f)

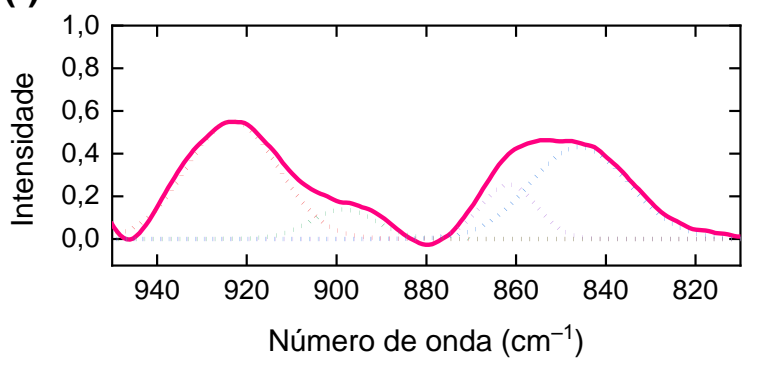

Fonte: Elaborado pela autora (2019).

Ao observar os espectros dos derivados de amido de mandioca da Figura 28 e da Figura 29, pode-se constar que $R_{1}$ e $R_{16}$ apresentaram espectros semelhantes, demonstrando que o aumento do $\mathrm{pH}$ de 10,0 para 11,0 e o da razão molar trimetafosfato trisódio por unidade de anidroglicose de 0,03 para 0,08 no meio de reticulação não promoveram ligações cruzadas entre as moléculas do amido de mandioca. 
Os resultados de espectroscopia de absorção no infravermelho demonstraram que as moléculas dos derivados reticulados de amido de mandioca não reticulam nas condições de reação estudadas.

Os espectros normalizados de absorção no infravermelho do amido de mandioca nativo e dos derivados acetilados indicaram a ocorrência de duas bandas. Uma na frequência de 1730 a $1715 \mathrm{~cm}^{-1}$ associada com o modo vibracional de $\mathrm{v}(\mathrm{C}=\mathrm{O})$ e outra na frequência de 1300 a $1200 \mathrm{~cm}^{-1}$ associada com o modo vibracional de $\mathrm{v}(\mathrm{C}-\mathrm{O})$, como pode ser observado na Figura 30.

Figura 30 - Espectros normalizados de absorção no infravermelho do (a) amido de mandioca nativo e dos derivados acetilados (pH 10,0 e $R_{\text {STMP:AGU }}$ 0,03), e dos (b) derivados acetilados (pH 11,0 e $R_{\text {STMP:AGU }}$ 0,03), e dos (c) derivados acetilados (pH 10,0 e $R_{\text {STMP:AGU }}$ 0,08), e do (d) derivado acetilado $\mathrm{RA}_{16}\left(\mathrm{pH} 11,0\right.$ e $\left.R_{\text {StMP:AGU }} 0,08\right)$.

(a)

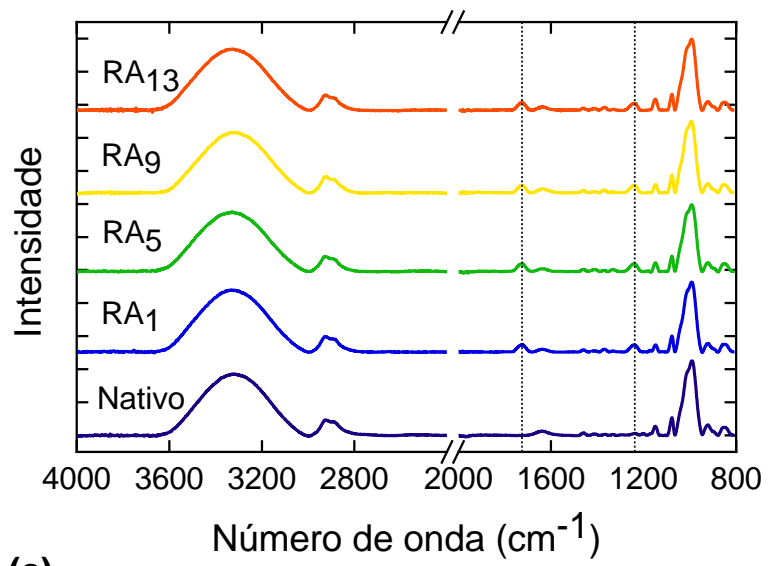

(c)

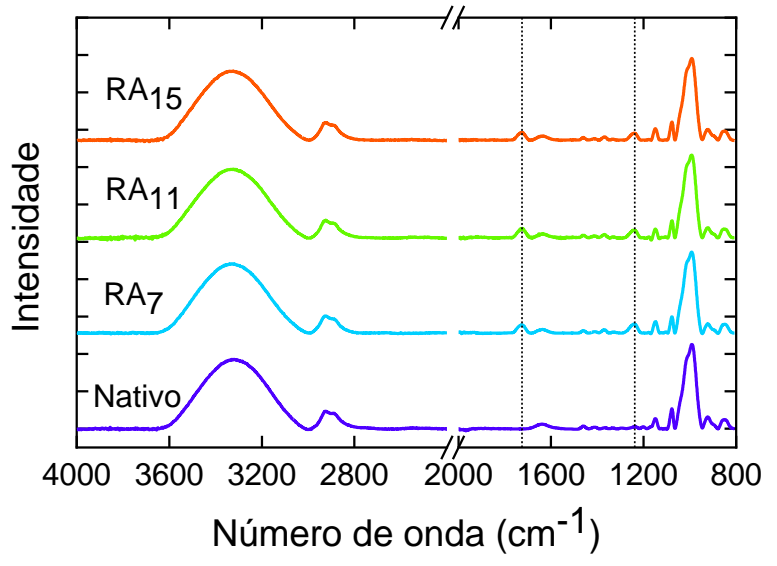

(b)

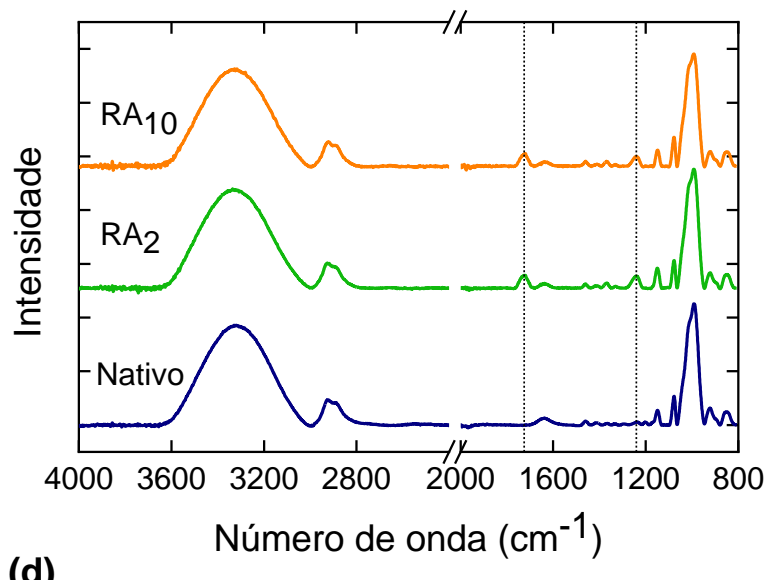

(d)

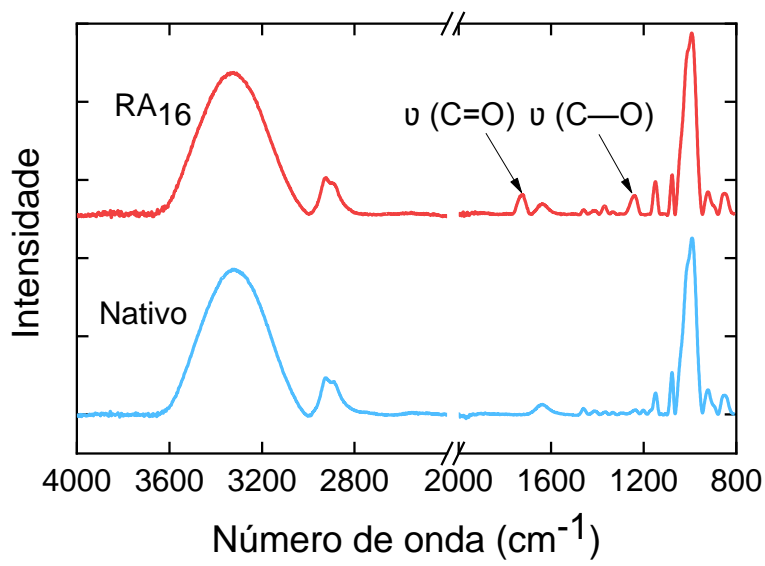

Fonte: Elaborado pela autora (2019). 
Observa-se na Figura 30 que as bandas ocorreram nas frequências próximo de $1727,4 \pm 0,2 \mathrm{~cm}^{-1}$ e de $1233,4 \pm 0,1 \mathrm{~cm}^{-1}$ e isso demonstra que as ligações estão em ésteres conjugados de acetato (SILVERSTEIN; BASSLER; MORRIL, 1991; PAVIA et al., 1987). Os espectros deconvoluídos de $R A_{1}$ e $R A_{16}$ nessas faixas de frequência podem ser visualizados na Figura 31, que destaca o centro das duas bandas.

Figura 31 - Comparação dos espectros deconvoluídos de absorção no infravermelho do derivado $\mathrm{RA}_{1}\left(\mathrm{pH} 10,0\right.$ e $R_{\text {STMP:AGU }} 0,03$ ) na faixa de frequência de (a) 3900 a $1500 \mathrm{~cm}^{-1}$ e na faixa de frequência de (b) 1500 a $1100 \mathrm{~cm}^{-1}$ com os espectros do derivado $R A_{16}(\mathrm{pH} 11,0 \mathrm{e}$ $R_{\text {STMP:AGU }} 0,08$ ) na faixa de frequência de (c) 3900 a $1500 \mathrm{~cm}^{-1}$ e na faixa de frequência de (d) 1500 a $1100 \mathrm{~cm}^{-1}$.

(a)

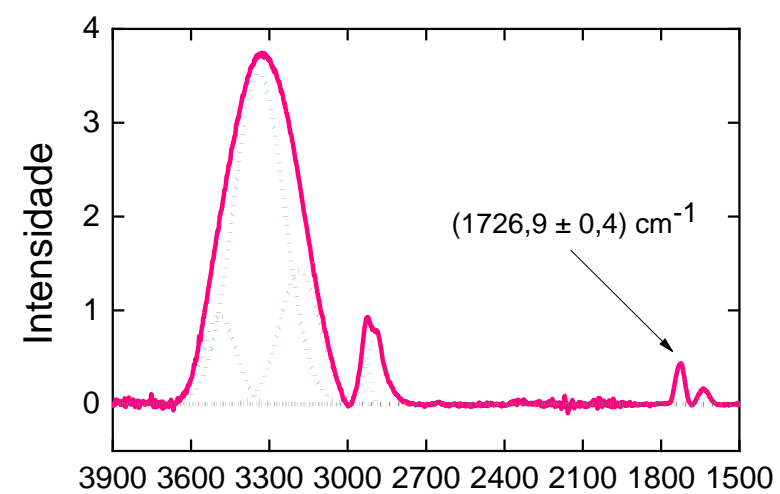

(c) Número de onda $\left(\mathrm{cm}^{-1}\right)$

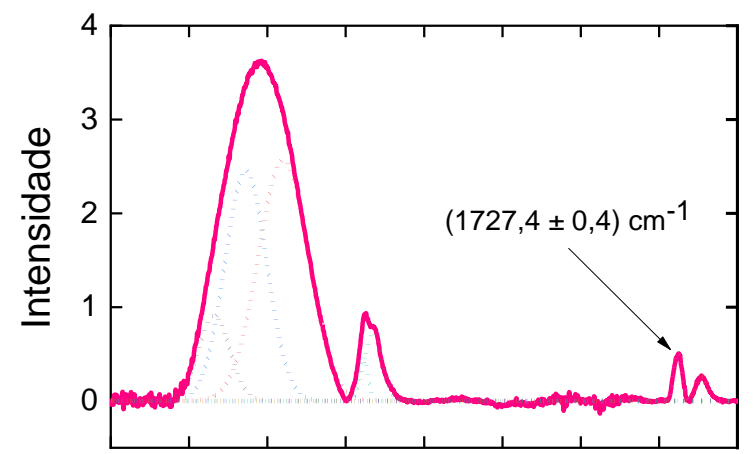

390036003300300027002400210018001500

Número de onda $\left(\mathrm{cm}^{-1}\right)$ (b)
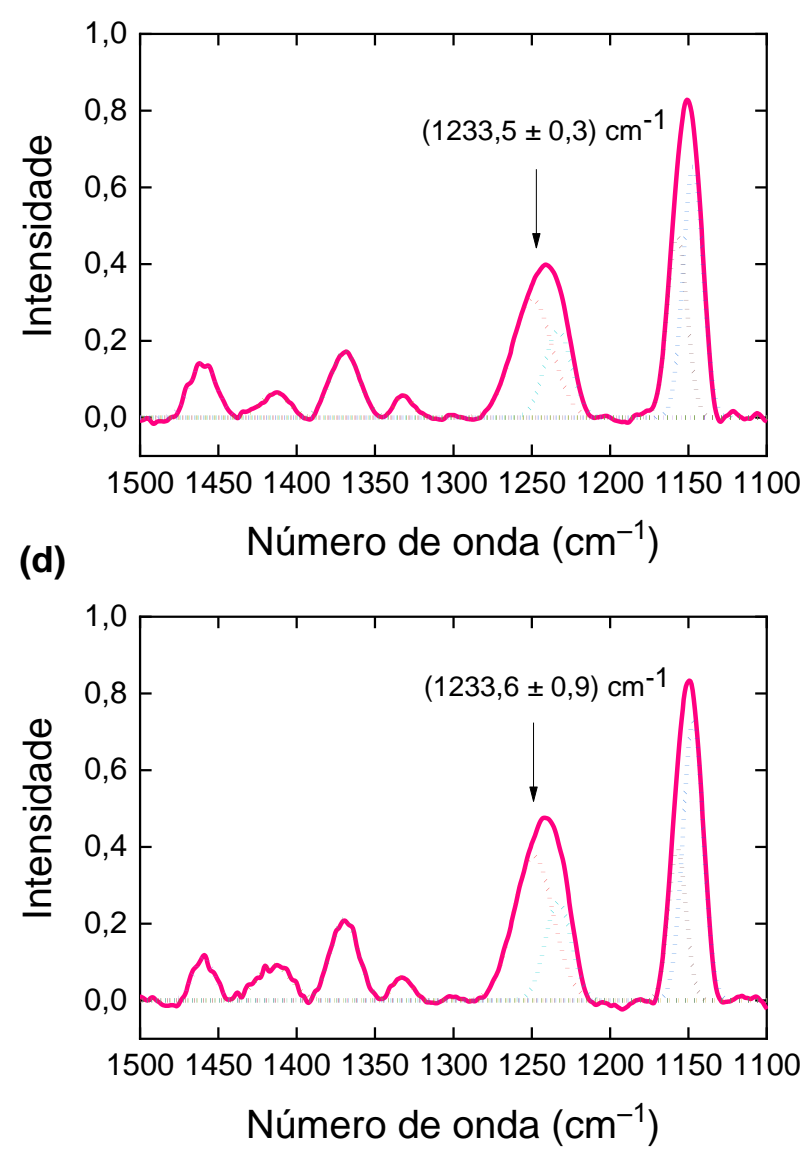

Fonte: Elaborado pela autora (2019).

Observa-se na Figura 31 que os espectros de absorção no infravermelho dos derivados $R_{1}$ e $R A_{16}$ deconvoluídos na região de 3900 a $1100 \mathrm{~cm}^{-1}$ apresentaram perfis semelhantes, apesar das condições do meio de reticulação distintas do derivado $\mathrm{R}_{1}$ (pH 10,0 e Rstmp:AGu 0,03) e do derivado $\mathrm{R}_{16}$ (pH 11,0 e Rstmp:AGu 0,08). 
A comparação dos espectros de absorção no infravermelho do amido de mandioca nativo e dos derivados acetilados na frequência de 1500 a $1100 \mathrm{~cm}^{-1}$ mostrou uma terceira banda entre 1400 a $1350 \mathrm{~cm}^{-1}$, como se observa na Figura 32 , referente a $R A_{15}, R A_{2}$ e $R A_{13}$.

Figura 32 - Comparação dos espectros deconvoluídos de absorção no infravermelho na faixa de frequência de 1500 a $1100 \mathrm{~cm}^{-1}$ do (a) amido de mandioca nativo, do (b) derivado $\mathrm{RA}_{13}\left(\mathrm{pH} 10,0\right.$ e $R_{\text {StMP:AGU }} 0,03$ ), do derivado (c) $\mathrm{RA}_{2}$ (pH 11,0 e $R_{\text {STMP:AGU }} 0,03$ ) e do (d) derivado $\mathrm{RA}_{15}\left(\mathrm{pH} 10,0\right.$ e $\left.R_{\mathrm{STMP}: A G \cup} 0,08\right)$, destacando a área da banda associada com o modo vibracional de $\delta_{\mathrm{s}}\left(-\mathrm{CH}_{3}\right)$ e de $\delta_{\mathrm{s}}(\mathrm{O}-\mathrm{H})$.

(a)

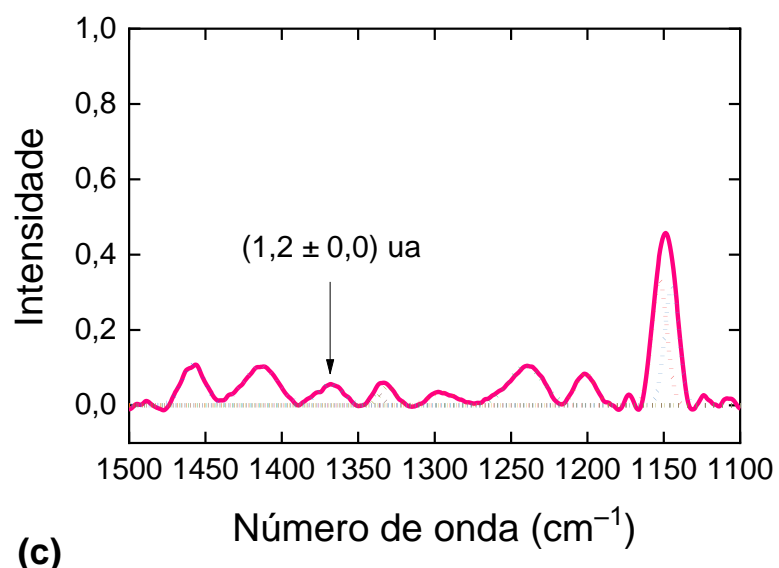

(c)

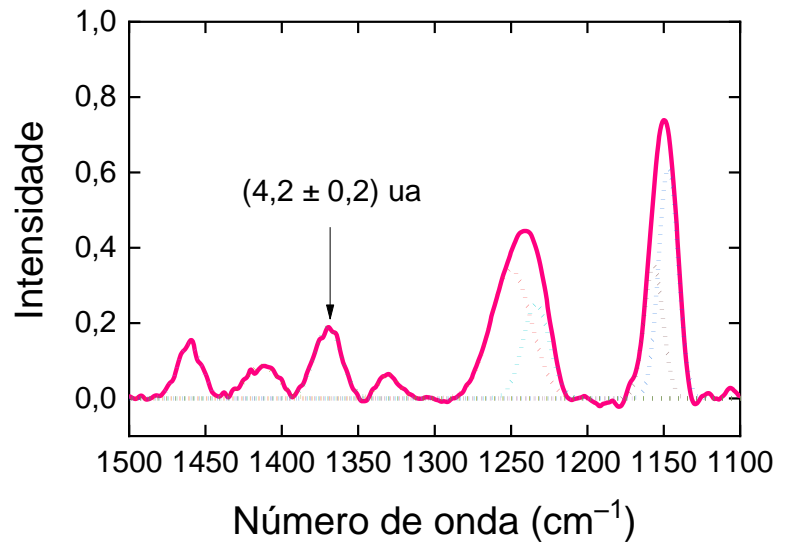

(b)
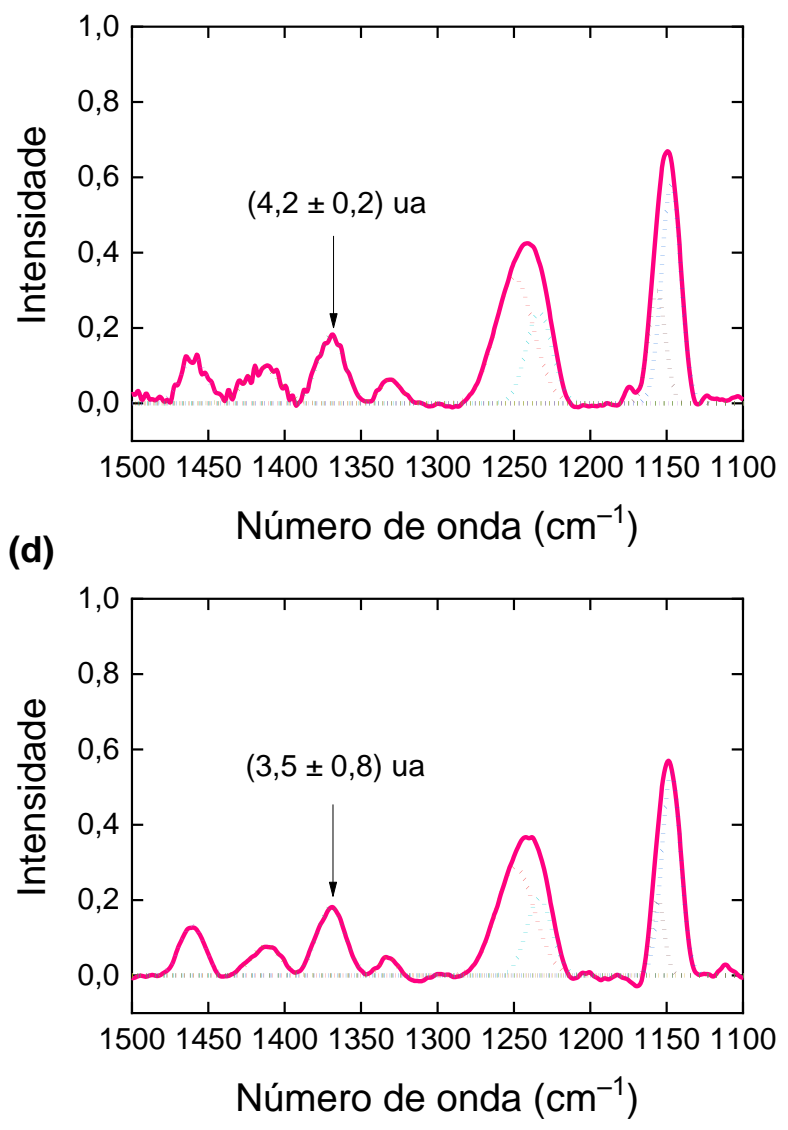

Fonte: Elaborado pela autora (2019).

Essa banda ocorreu na região do espectro que está associada com o modo vibracional de $\delta_{\mathrm{s}}\left(-\mathrm{CH}_{3}\right)$ e com o de $\delta_{\mathrm{s}}(\mathrm{O}-\mathrm{H})$ em ácidos carboxílicos, demonstrando a presença de ácido acético no interior dos grânulos do amido acetilado (SILVERSTEIN; BASSLER; MORRIL, 1974). Observa-se também na Figura 32 que a 
intensidade de radiação absorvida foi semelhante, como indica a área desta banda nos espectros de $R A_{15}, R A_{2}$ e $R A_{13}$.

Tudo aponta para o fato que a acetilação das moléculas do amido de mandioca não foi influenciada pelas condições do meio de reticulação, denotando ausência de grupos fosfato.

Os resultados de espectroscopia de absorção no infravermelho confirmaram que grupos acetila $\left(\mathrm{CH}_{3} \mathrm{CO}-\right)$ foram inseridos nas moléculas do amido e evidenciaram a presença de ácido acético no interior dos grânulos dos derivados acetilados de amido de mandioca. 


\subsection{PARÂMETROS DE GELATINIZAÇÃO DO AMIDO DE MANDIOCA QUIMICAMENTE MODIFICADO}

Independentemente do tipo de modificação química e das condições do meio de reticulação, as curvas de microcalorimetria exploratória diferencial ( $\mu \mathrm{DSC}$ ) mostraram uma transição endotérmica principal que corresponde à gelatinização $\left(\mathrm{M}_{1}\right)$, uma segunda transição endotérmica $\left(\mathrm{M}_{2}\right)$ que corresponde à fusão de cristais de amilopectina mais estáveis e duas transições $\left(L_{1}\right.$ e $\left.L_{2}\right)$ que correspondem a conformações das moléculas de amilopectina após a solubilização do grânulo.

As curvas de $\mu \mathrm{DSC}$ do amido de mandioca nativo serviram de referência para identificar alterações no comportamento de gelatinização dos derivados reticulados e acetilados de mandioca. A Figura 33 traz as curvas dos ensaios com o amido de mandioca nativo.

Figura 33 - Curvas de $\mu \mathrm{DSC}$ com a linha de base corrigida do primeiro (a) e do segundo ensaio (b) do amido de mandioca nativo na razão mássica amido:água 1:3.

(a)

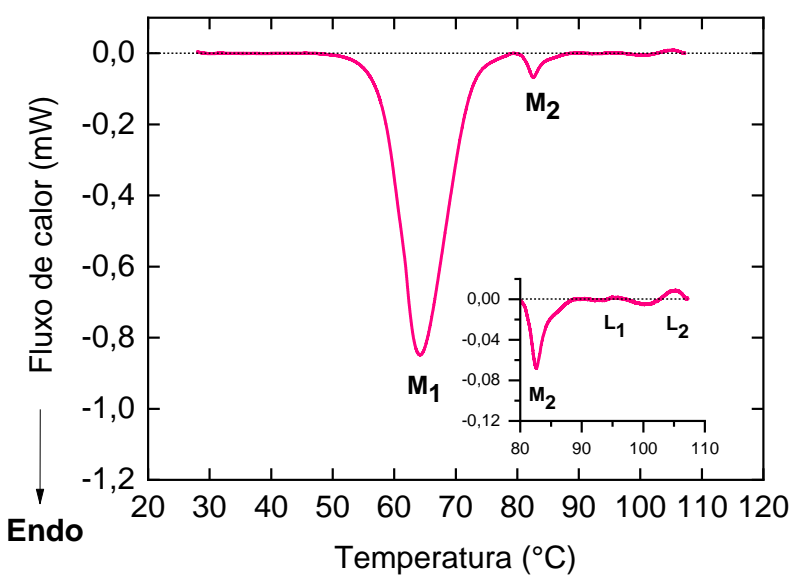

(b)

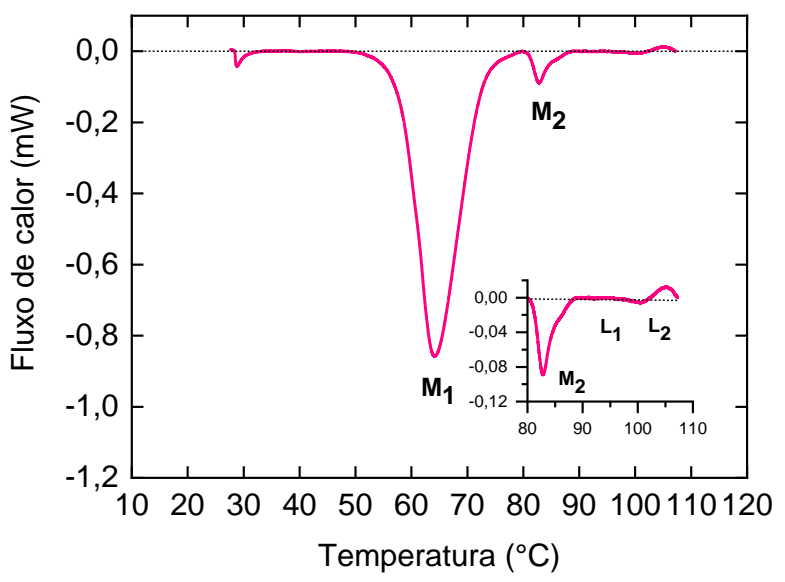

Fonte: Elaborado pela autora (2019).

Como pode ser observado na Figura 33, o pico endotérmico da gelatinização $\left(M_{1}\right)$ ocorreu entre 50 e $80^{\circ} \mathrm{C}$. Essa é a transição principal ao longo do aquecimento e ocorre quando os cristais de amilopectina se desprendem da rede cristalina e as hélices duplas recém-fundidas se desemparelham.

Observa-se também na Figura 33 que uma segunda transição endotérmica $\left(\mathrm{M}_{2}\right)$, cujo formato de sino do pico é semelhante ao do pico de gelatinização, ocorreu 
entre 80 e $90^{\circ} \mathrm{C}$ e também corresponde à fusão dos cristais de amilopectina, só que dos cristais mais estáveis

A linha de base do instrumento não se reestabeleceu entre os picos de gelatinização e o da segunda transição endotérmica, como pode ser verificado na Figura 33. Múltiplas transições endotérmicas desse tipo no amido de mandioca revelam a heterogeneidade dos cristais de amilopectina no grânulo.

As transições $L_{1}$ e $L_{2}$ ocorreram entre 85 e $110{ }^{\circ} \mathrm{C}$ e apresentaram caráter exotérmico no início que mudou para endotérmico e novamente exotérmico conforme a temperatura aumentou, como mostrado nos detalhes da Figura 33 (a) e da Figura 33 (b).

Os valores médios de temperatura e entalpia de gelatinização do amido de mandioca nativo, determinados por meio das curvas de $\mu$ DSC da Figura 33, foram $64,7^{\circ} \mathrm{C}$ e $14,9 \mathrm{~J} \mathrm{~g}^{-1}$, respectivamente.

Isto posto, as curvas de $\mu \mathrm{DSC}$ dos derivados reticulados de amido de mandioca mostraram as mesmas transições exibidas pelas curvas de $\mu$ DSC do amido nativo. Entretanto, em alguns casos a segunda transição endotérmica não ocorreu e em outros a $L_{1}$, como pode ser visto na Figura 34, referente ao derivado $R_{1}(\mathrm{pH} 10,0$ e Rstmp:AGu 0,03) e ao $\mathrm{R}_{10}$ (pH 11,0 e Rstmp:AGu 0,03).

Figura 34 - Curvas de $\mu$ DSC com a linha de base corrigida do (a) derivado $R_{1}(p H 10,0$ e $R_{\text {StMP:AGU }}$ 0,03) na razão mássica água:amido de 3,0 e do (b) derivado $R_{10}(\mathrm{pH} 11,0 \mathrm{e}$ $R_{\text {StMP:AGu }} 0,03$ ) na razão mássica amido:água 1:3.
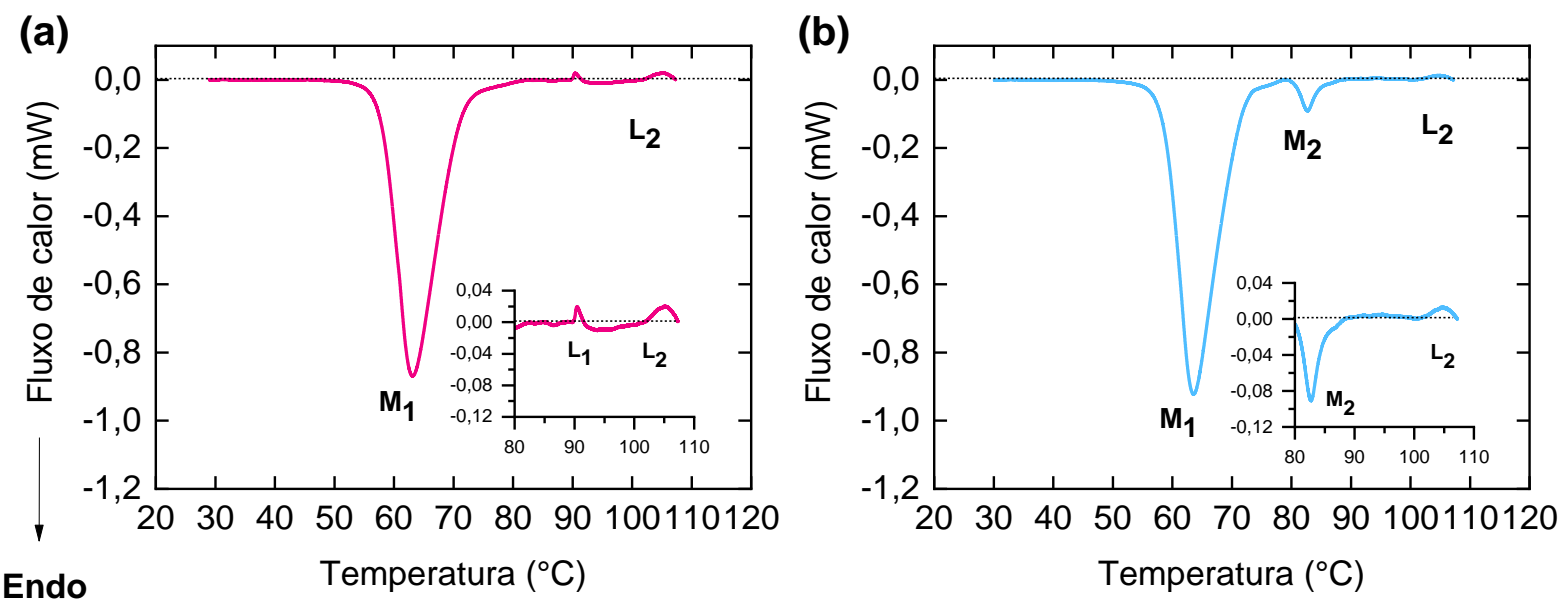

Fonte: Elaborado pela autora (2019). 
Nota-se ainda na Figura 34 (b) que, assim como nas curvas do amido de mandioca nativo, a linha de base do instrumento não se reestabeleceu entre o pico de gelatinização e o segundo pico endotérmico.

Ao lado do pico de gelatinização, $L_{2}$ foi a transição que persistiu nas curvas $\mu \mathrm{DSC}$ dos derivados reticulados e normalmente ocorreu próximo de $105^{\circ} \mathrm{C}$, como pode ser visualizado na Figura 35, cujas curvas são de $R_{11}\left(p H 10,0\right.$ e $R_{\text {StMP:AGu }}$ 0,08).

Figura 35 - Curvas de $\mu \mathrm{DSC}$ com a linha de base corrigida do primeiro (a) e do segundo ensaio (b) do derivado $\mathrm{R}_{11}\left(\mathrm{pH}\right.$ 10,0 e $R_{\mathrm{STMP}: A G U}$ 0,03) na razão mássica amido:água 1:3.

(a)

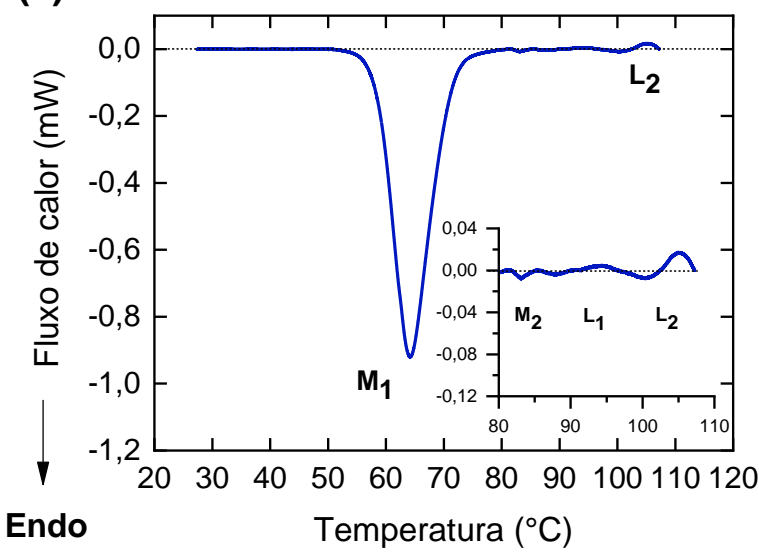

(b)

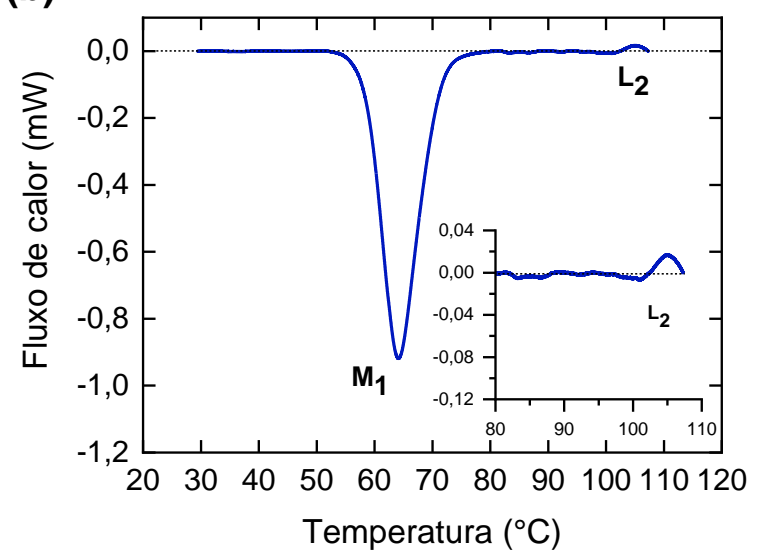

Fonte: Elaborado pela autora (2019).

A transição $L_{1}$ não ocorreu em uma curva e o segundo pico endotérmico não ocorreu na outra, como pode ser verificado nos detalhes da Figura 35 (a) e Figura 35 (b), respectivamente.

Essa variabilidade do comportamento na gelatinização dos derivados reticulados refletiu na deconvolução das curvas de $\mu$ DSC. O ajuste de duas funções gaussianas ao pico de gelatinização não convergiu para todos os casos, como o mostrado na Figura 36, referente também a $R_{11}$. 
Figura 36 - Curvas de $\mu \mathrm{DSC}$ com a linha de base corrigida do primeiro ensaio do derivado $\mathrm{R}_{11}$ (pH 10,0 e $R_{\text {StMP:AGU }}$ 0,03) deconvoluída no tempo (a) e do segundo ensaio de $R_{11}$ deconvoluída na temperatura (b) na razão mássica amido:água 1:3.

(a)

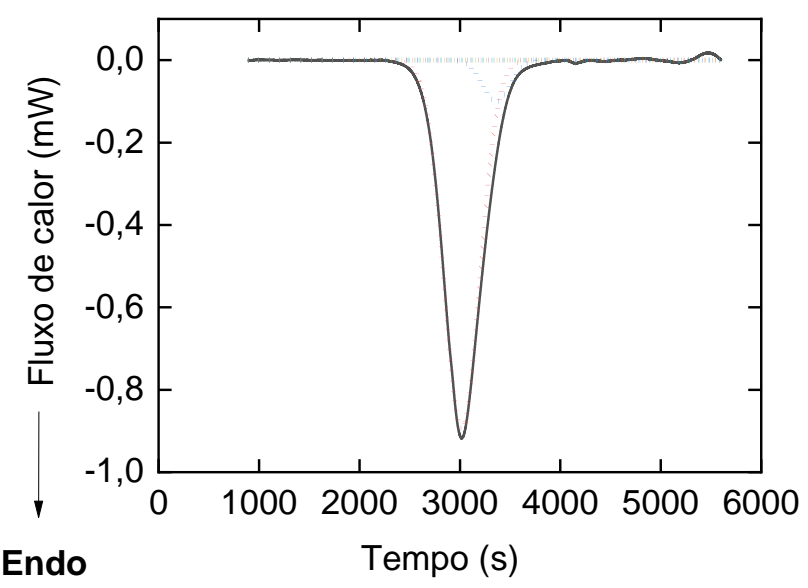

(b)

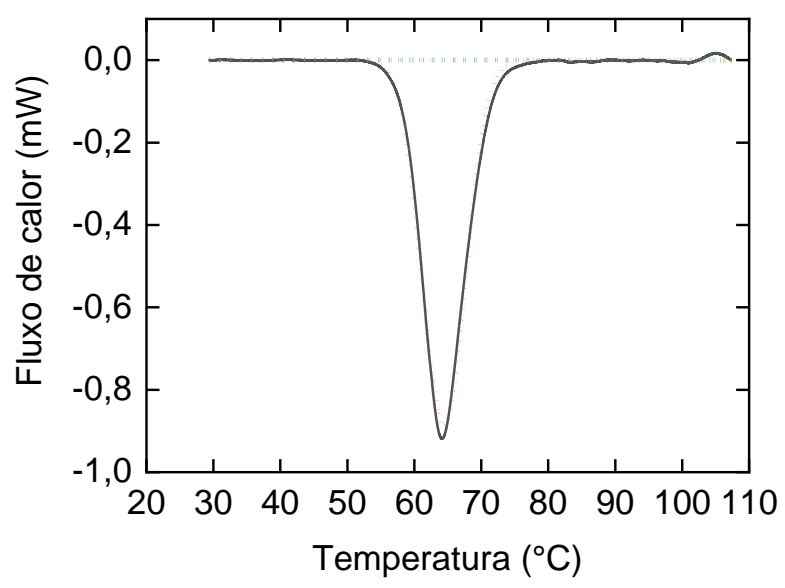

Fonte: Elaborado pela autora (2019).

Observa-se na Figura 36 que o pico de gelatinização de uma curva de $\mathrm{R} 11$ foi deconvoluído por uma única função gaussiana porque o ajuste da segunda função ao pico não convergiu. Nesse caso, os valores dos parâmetros de gelatinização do derivado diferem, sendo o valor de entalpia de gelatinização o mais afetado.

Os parâmetros de gelatinização dos derivados reticulados de amido de mandioca estão apresentados na Tabela 8. 
Tabela 8 - Valores médios dos parâmetros de gelatinização dos derivados reticulados de amido de mandioca separados por condição de reação nos experimentos de síntese dos derivados reticulados

\begin{tabular}{|c|c|c|c|c|c|c|c|}
\hline \multirow[b]{2}{*}{ Condição de reação } & \multirow[b]{2}{*}{ Derivado } & \multicolumn{6}{|c|}{ Parâmetros de gelatinização ${ }^{1}$} \\
\hline & & $\begin{array}{c}A \\
(\mathrm{~mW})\end{array}$ & $\begin{array}{c}F W H M \\
(\mathrm{~s})\end{array}$ & $\begin{array}{c}\Delta_{\mathrm{m}} H \\
\left(\mathrm{~J} \mathrm{~g}^{-1}\right)\end{array}$ & $\begin{array}{c}T_{\mathrm{m}} \\
\left({ }^{\circ} \mathrm{C}\right)\end{array}$ & $\begin{array}{l}T_{\mathrm{m}, \mathrm{i}} \\
\left({ }^{\circ} \mathrm{C}\right)\end{array}$ & $\begin{array}{l}T_{\mathrm{m} . \mathrm{f}} \\
\left({ }^{\circ} \mathrm{C}\right)\end{array}$ \\
\hline \multirow[t]{4}{*}{ \#1 (Grupo 1) } & $\mathrm{R}_{1}$ & 0,8 & 372,0 & 10,7 & 63,2 & 57,8 & 68,6 \\
\hline & $\mathrm{R}_{5}$ & 0,8 & 470,2 & 14,2 & 63,4 & 58,0 & 68,8 \\
\hline & R9 & 0,9 & 463,2 & 14,2 & 63,2 & 58,1 & 68,4 \\
\hline & $\mathrm{R}_{13}$ & 0,8 & 384,4 & 11,2 & 63,5 & 57,9 & 69,0 \\
\hline \multirow[t]{4}{*}{ \#2 (Grupo 2) } & $\mathrm{R}_{2}$ & 0,9 & 452,8 & 14,2 & 63,3 & 58,4 & 68,2 \\
\hline & $\mathrm{R}_{6}$ & - & - & - & - & - & - \\
\hline & $\mathrm{R}_{10}$ & 0,9 & 344,9 & 10,6 & 63,5 & 58,6 & 68,5 \\
\hline & $\mathrm{R}_{14}$ & - & - & - & - & - & - \\
\hline \multirow[t]{4}{*}{ \#3 (Grupo 3) } & $\mathrm{R}_{3}$ & - & - & - & - & - & - \\
\hline & $\mathrm{R}_{7}$ & 0,9 & 389,5 & 12,2 & 63,9 & 58,4 & 69,5 \\
\hline & $\mathrm{R}_{11}$ & 0,9 & 418,3 & 13,5 & 64,2 & 58,2 & 70,2 \\
\hline & $\mathrm{R}_{15}$ & 0,9 & 398,2 & 12,1 & 63,6 & 57,9 & 69,3 \\
\hline \multirow[t]{4}{*}{ \#4 (Grupo 4) ${ }^{2}$} & $\mathrm{R}_{4}$ & - & - & - & - & - & - \\
\hline & $\mathrm{R}_{8}$ & - & - & - & - & - & - \\
\hline & $\mathrm{R}_{12}$ & - & - & - & - & - & - \\
\hline & $\mathrm{R}_{16}$ & 0,9 & 416,7 & 13,6 & 65,2 & 59,2 & 71,2 \\
\hline
\end{tabular}

Fonte: Elaborado pela autora (2019).

(1) Valores médios da duplicata.

(2) Grupo excluído da análise por falta de resultado.

* O teste de Levene não paramétrico verificou a homogeneidade de variância $(p>0,05)$ dos dados.

As curvas de $\mu \mathrm{DSC}$ dos derivados acetilados de amido de mandioca mostraram o pico de gelatinização $\left(\mathrm{M}_{1}\right)$ deslocado para uma faixa de temperatura 45 a $70{ }^{\circ} \mathrm{C}$ 
menor em relação a dos derivados reticulados 50 a $80^{\circ} \mathrm{C}$, como pode ser visualizado na Figura 37, referente ao derivado $\mathrm{RA}_{1}(\mathrm{pH} 10,0$ e Rstmp:AGu 0,03).

Figura 37 - Curvas de $\mu \mathrm{DSC}$ com a linha de base corrigida do primeiro (a) e do segundo ensaio (b) do derivado $\mathrm{RA}_{1}\left(\mathrm{pH} 10,0\right.$ e $\left.R_{\text {STMP:AGU }} 0,03\right)$ na razão mássica amido:água 1:3.

(a)

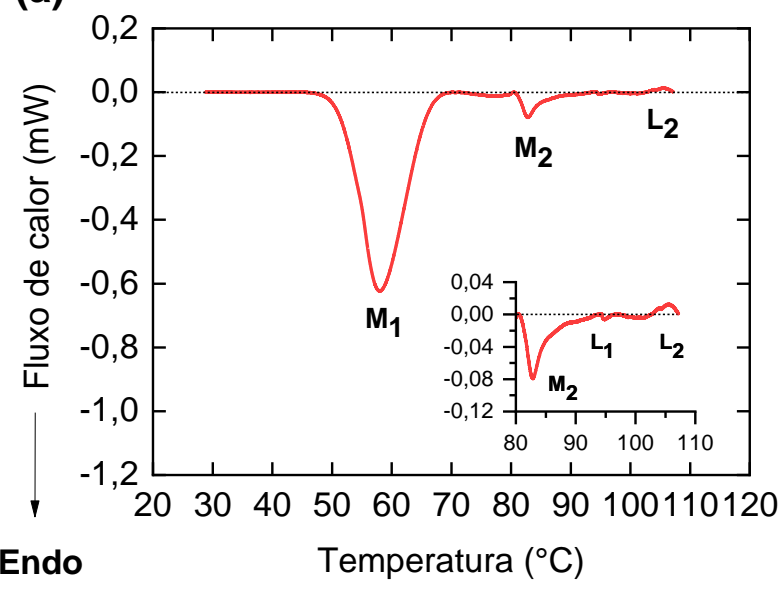

(b)

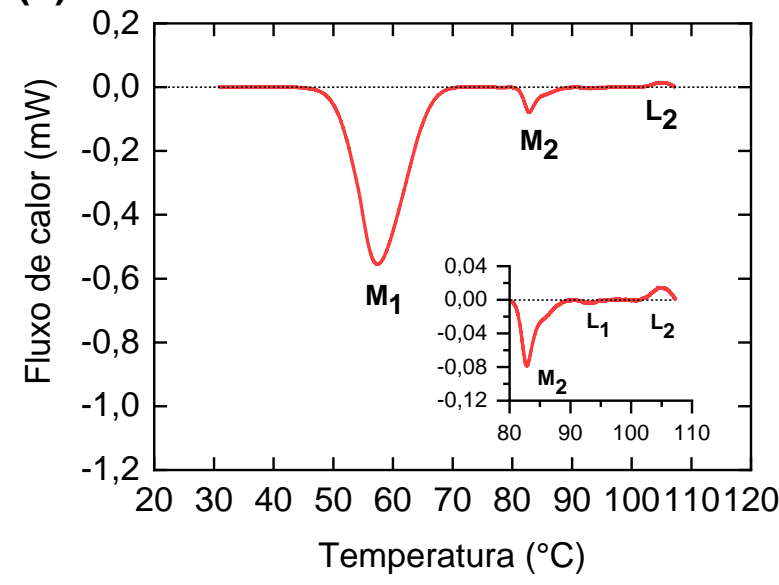

Fonte: Elaborado pela autora (2019).

Nota-se nas curvas $\mu \mathrm{DSC}$ de RA 1 mostradas na Figura 37 que o fluxo de calor máximo registrado também diminuiu em relação ao registrado pelas curvas de $\mu \mathrm{DSC}$ dos derivados reticulados de amido de mandioca.

As curvas de $\mu \mathrm{DSC}$ dos derivados acetilados também mostraram o pico da segunda transição endotérmica $\left(\mathrm{M}_{2}\right)$, a qual ocorreu na mesma faixa de temperatura 80 a $90^{\circ} \mathrm{C}$ daquelas nas curvas dos derivados reticulados de amido, como pode ser visto na Figura 38 cujas curvas são do derivado RA2 (pH 11,0 e Rstmp:AGu 0,03). 
Figura 38 - Curvas de $\mu$ DSC com a linha de base corrigida do primeiro (a) e do segundo ensaio (b) do derivado $\mathrm{RA}_{2}$ (pH 11,0 e $R_{\mathrm{StMP}: A G U}$ 0,03) na razão mássica amido:água 1:3.

(a)

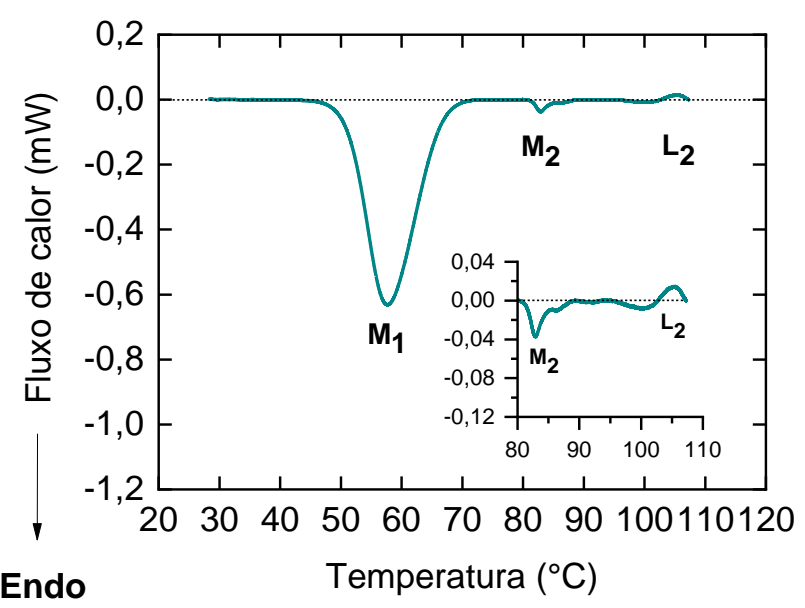

(b)

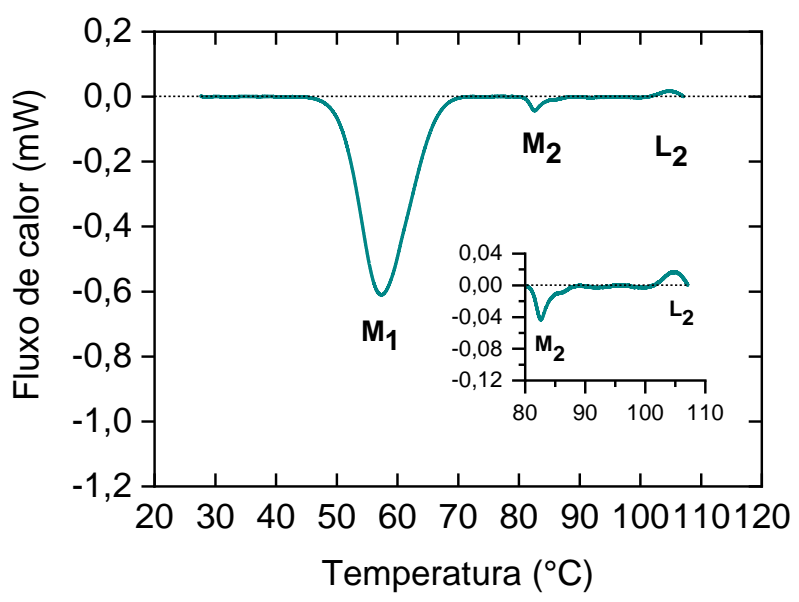

Fonte: Elaborado pela autora (2019).

Observa-se na Figura 38, assim como na Figura 37, que a linha de base do microcalorímetro se reestabeleceu entre o pico de gelatinização $\left(M_{1}\right)$ e o pico da segunda transição endotérmica $\left(\mathrm{M}_{2}\right)$.

Nos detalhes da Figura 38 (a) e da Figura 38 (b), observa-se a transição $L_{1}$ não ocorreu em todas as curvas de $\mu \mathrm{DSC}$ dos derivados acetilados. Do contrário, a transição $L_{2}$ persistiu nas curvas de $\mu \mathrm{DSC}$ de todos os derivados acetilados de amido de mandioca.

Algumas curvas de $\mu \mathrm{DSC}$ dos derivados acetilados, além de $L_{1}$, também não mostraram a segunda transição endotérmica $\left(\mathrm{M}_{2}\right)$, como pode ser visualizado nas

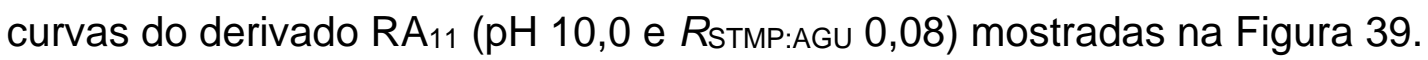


Figura 39 - Curvas de $\mu \mathrm{DSC}$ com a linha de base corrigida do primeiro (a) e do segundo ensaio (b) do derivado $\mathrm{RA}_{11}\left(\mathrm{pH}\right.$ 10,0 e $R_{\mathrm{STMP}: A G U}$ 0,08) na razão mássica amido:água 1:3.

(a)

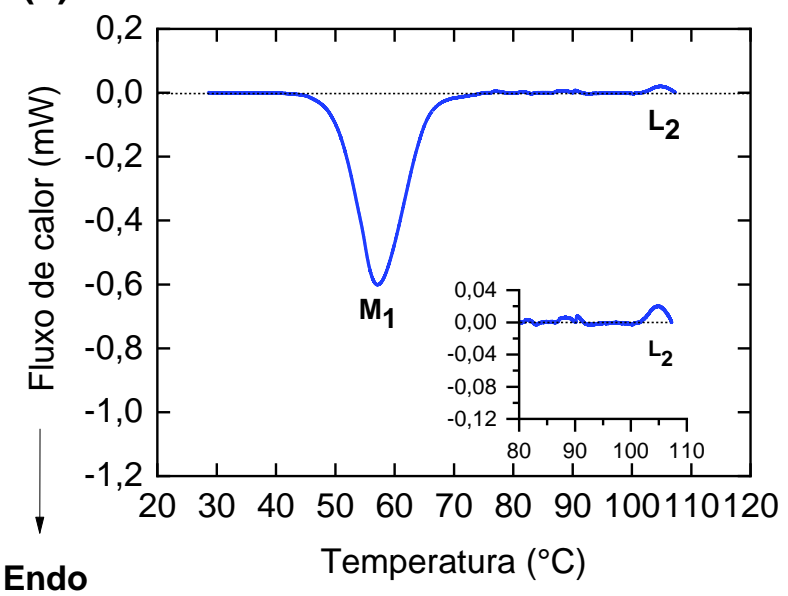

(b)

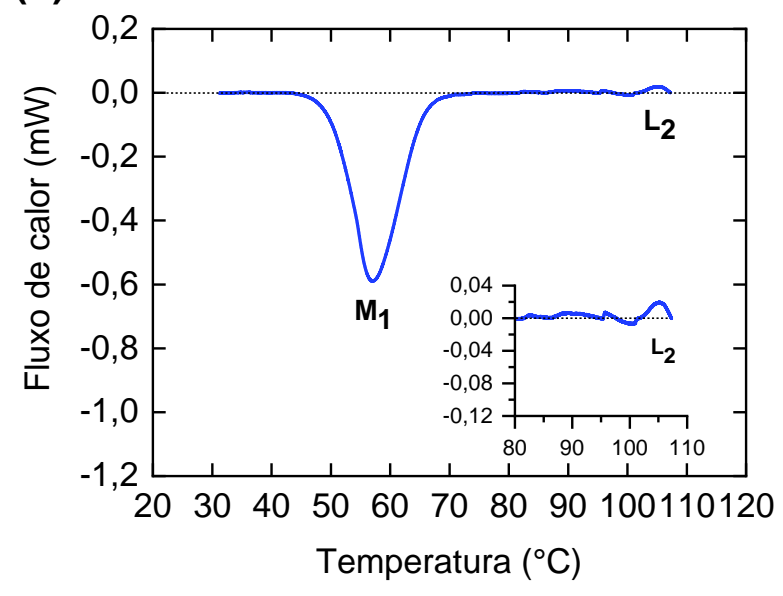

Fonte: Elaborado pela autora (2019).

Visualiza-se nos detalhes da Figura 39.(a) e da Figura 39 (b) oscilações da linha de base do instrumento nos lugares em que as transições $M_{2}$ e $L_{1}$ normalmente ocorreram.

As curvas de $\mu \mathrm{DSC}$ dos derivados acetilados de amido de mandioca evidenciaram que o pico de gelatinização foi influenciado pela acetilação das moléculas do amido de mandioca. A presença de grupos acetila nas moléculas do amido e a de ácido acético nos grânulos do amido de mandioca provocaram o abaixamento das temperaturas pico de gelatinização.

Semelhante à deconvolução das curvas de $\mu \mathrm{DSC}$ dos derivados reticulados, as diferenças nos perfis das curvas dos derivados acetilados se refletiram na convolução do sinal de fluxo de calor do pico de gelatinização, como no caso do derivado $\mathrm{RA}_{1}$ e no do derivado $\mathrm{RA}_{14}(\mathrm{pH} 11,0$ e Rstmp:Agu 0,03) apresentados na Figura 40. 
Figura 40 - Curvas de $\mu$ DSC com a linha de base corrigida do primeiro ensaio do derivado

$\mathrm{RA}_{1}$ (pH 10,0 e RStMP:AGu 0,03) deconvoluída (a) no tempo e do segundo ensaio deconvoluída na (b) temperatura na razão mássica amido:água 1:3, e do primeiro ensaio do derivado $\mathrm{RA}_{14}\left(\mathrm{pH} 11,0\right.$ e $R_{\mathrm{STMP}: A G \cup} 0,03$ ) deconvoluída no (c) tempo e do segundo ensaio deconvoluída na (d) temperatura.

(a)

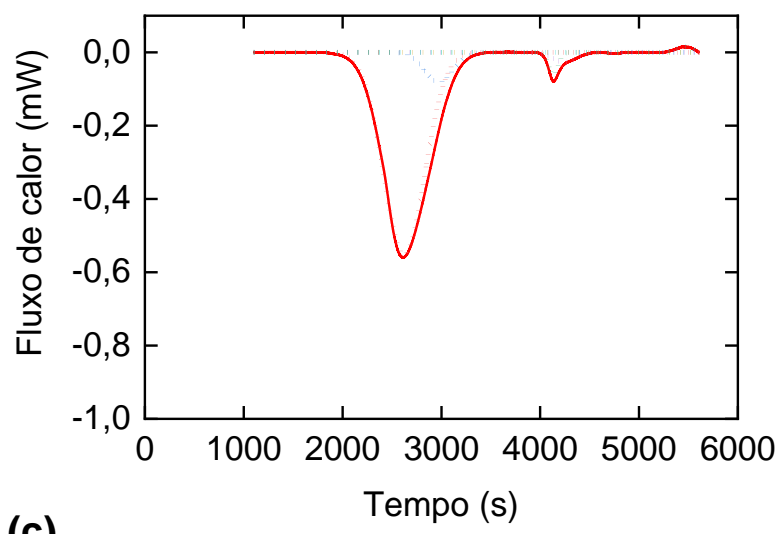

(c)

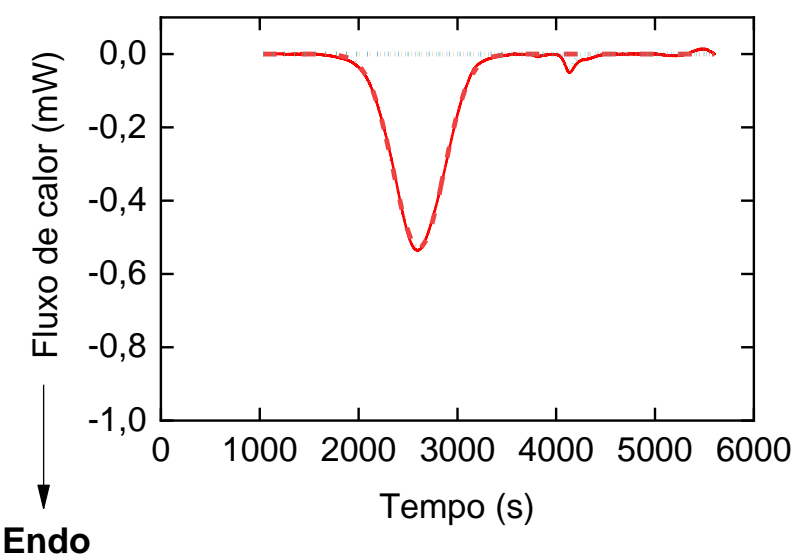

(b)

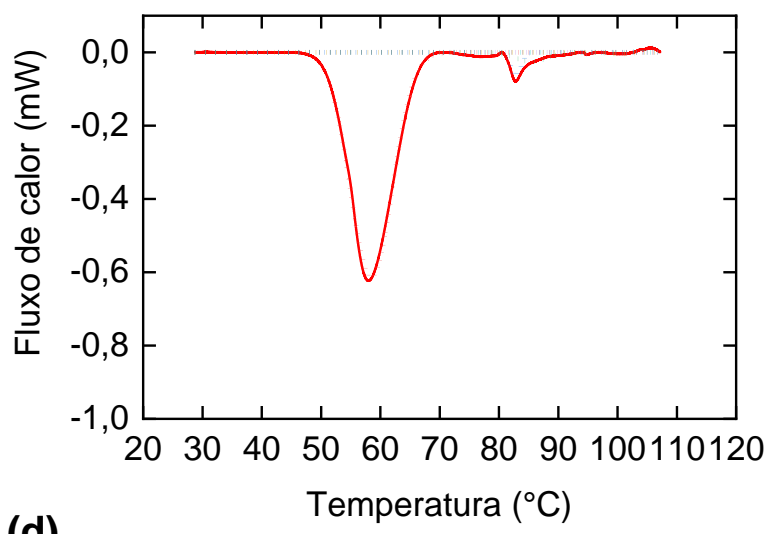

(d)

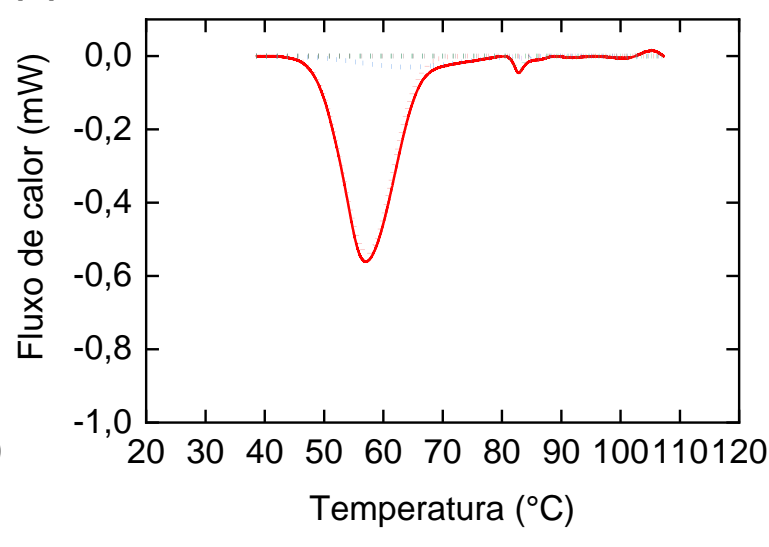

Fonte: Elaborado pela autora (2019).

Observa-se na Figura 40 (a), a deconvolução do pico de gelatinização por duas funções gaussiana de uma das curvas de $R A_{1}$. A deconvolução do pico de gelatinização por uma única função foi o caso, também, de $\mathrm{RA}_{1}$ e de uma curva de $\mathrm{RA}_{14}$, como mostram a Figura 40 (b) e a Figura 40 (c), respectivamente.

Uma exceção a essas duas situações foi a deconvolução da curva de $\mu \mathrm{DSC}$ de $R_{14}$, a qual está mostrada na Figura 40 (d), a altura da segunda função gaussiana diminuiu. $\mathrm{O}$ achatamento da função foi por causa da linha de base do instrumento que levou mais tempo para se reestabelecer após o pico de gelatinização.

Dessa forma, os parâmetros de gelatinização dos derivados acetilados de amido de mandioca estão apresentados na Tabela 9. 
Tabela 9 - Valores médios dos parâmetros de gelatinização dos derivados acetilados de amido de mandioca separados por condição de reação na reticulação

\begin{tabular}{|c|c|c|c|c|c|c|c|}
\hline \multirow[b]{2}{*}{ Condição de reação } & \multirow[b]{2}{*}{ Derivado } & \multicolumn{6}{|c|}{ Parâmetros de gelatinização ${ }^{1}$} \\
\hline & & $\begin{array}{c}A \\
(\mathrm{~mW})\end{array}$ & $\begin{array}{c}F W H M \\
(\mathrm{~s})\end{array}$ & $\begin{array}{c}\Delta_{\mathrm{m}} H \\
\left(\mathrm{~J} \mathrm{~g}^{-1}\right)\end{array}$ & $\begin{array}{c}T_{\mathrm{m}} \\
\left({ }^{\circ} \mathrm{C}\right)\end{array}$ & $\begin{array}{l}T_{\mathrm{m}, \mathrm{i}} \\
\left({ }^{\circ} \mathrm{C}\right)\end{array}$ & $\begin{array}{l}T_{\mathrm{m}, \mathrm{f}} \\
\left({ }^{\circ} \mathrm{C}\right)\end{array}$ \\
\hline \multirow[t]{4}{*}{ \#1 (Grupo 5) } & $\mathrm{RA}_{1}$ & 0,6 & 515,4 & 10,8 & 58,2 & 50,8 & 65,6 \\
\hline & $\mathrm{RA}_{5}$ & 0,6 & 561,0 & 10,8 & 57,7 & 49,6 & 65,8 \\
\hline & $\mathrm{RA} 9$ & 0,6 & 538,9 & 10,3 & 57,8 & 50,1 & 65,7 \\
\hline & $\mathrm{RA}_{13}$ & 0,6 & 548,1 & 10,9 & 58,3 & 50,5 & 66,1 \\
\hline \multirow[t]{4}{*}{ \#2 (Grupo 6) } & $\mathrm{RA}_{2}$ & 0,6 & 491,5 & 9,9 & 57,6 & 50,6 & 64,5 \\
\hline & $\mathrm{RA}_{6}$ & - & - & - & - & - & - \\
\hline & $\mathrm{RA}_{10}$ & 0,6 & 544,0 & 10,8 & 58,3 & 50,6 & 66,0 \\
\hline & $\mathrm{RA}_{14}$ & 0,5 & 589,6 & 11,0 & 57,4 & 49,1 & 65,8 \\
\hline \multirow[t]{4}{*}{ \#3 (Grupo 7) } & $\mathrm{RA}_{3}$ & - & - & - & - & - & - \\
\hline & $\mathrm{RA}_{7}$ & 0,6 & 554,3 & 10,8 & 57,4 & 49,4 & 65,3 \\
\hline & $\mathrm{RA}_{11}$ & 0,6 & 546,2 & 11,2 & 57,5 & 49,8 & 65,2 \\
\hline & $\mathrm{RA}_{15}$ & 0,6 & 555,2 & 11,5 & 57,6 & 49,7 & 65,6 \\
\hline \multirow[t]{4}{*}{ \#4 (Grupo 8)² } & $\mathrm{RA}_{4}$ & - & - & - & - & - & - \\
\hline & $\mathrm{RA}_{8}$ & - & - & - & - & - & - \\
\hline & $R A_{12}$ & - & - & - & - & - & - \\
\hline & $\mathrm{RA}_{16}$ & 0,5 & 544,9 & 9,54 & 56,2 & 48,6 & 63,6 \\
\hline
\end{tabular}

Fonte: Elaborado pela autora (2019).

(1) Valores médios da duplicata.

(2) Grupo excluído da análise por falta de resultado.

* O teste de Levene não paramétrico verificou a homogeneidade de variância $(p>0,05)$ dos dados.

O resultado da comparação entre os grupos dos derivados reticulados e os grupos dos derivados acetilados de amido de mandioca, com base nas condições do meio de reticulação, está mostrado na Tabela 10. 
Tabela 10 - Valores (Média \pm Desvio Padrão) dos parâmetros de gelatinização dos derivados de amido de mandioca comparados com base nas condições de reação da reticulação e na acetilação dos derivados reticulados de amido de mandioca

\begin{tabular}{|c|c|c|c|c|c|c|c|c|}
\hline \multirow[b]{2}{*}{ Grupo(1) } & \multicolumn{2}{|c|}{ Condiçoes de reação } & \multicolumn{6}{|c|}{ Parâmetros de gelatinização } \\
\hline & $\mathrm{pH}$ & $R_{\mathrm{STMP}: \mathrm{AGU}}$ & $A(\mathrm{~mW})$ & $F W H M(s)$ & $\Delta_{\mathrm{m}} H\left(\mathrm{~J} \mathrm{~g}^{-1}\right)$ & $T_{\mathrm{m}}\left({ }^{\circ} \mathrm{C}\right)$ & $T_{\mathrm{m}, \mathrm{i}}\left({ }^{\circ} \mathrm{C}\right)$ & $T_{\mathrm{m}, \mathrm{f}}\left({ }^{\circ} \mathrm{C}\right)$ \\
\hline 1 & 10,0 & 0,03 & $0,8 \pm 0,0^{a}$ & $422,4 \pm 51,4^{a}$ & $12,6 \pm 1,9^{a}$ & $63,5 \pm 0,5^{a}$ & $57,9 \pm 0,2^{a}$ & $69,2 \pm 1,1^{a}$ \\
\hline 2 & 11,0 & 0,03 & $0,9 \pm 0,0^{a}$ & $398,9 \pm 76,3^{a}$ & $12,4 \pm 2,6^{a}$ & $63,4 \pm 0,2^{a}$ & $58,4 \pm 0,2^{a}$ & $68,4 \pm 0,2^{a}$ \\
\hline 3 & 10,0 & 0,08 & $0,9 \pm 0,0^{a}$ & $402,0 \pm 14,8^{a}$ & $12,5 \pm 0,5^{a}$ & $63,9 \pm 0,3^{a}$ & $58,2 \pm 0,2^{a}$ & $69,6 \pm 0,5^{a}$ \\
\hline 5 & 10,0 & 0,03 & $0,6 \pm 0,0^{b}$ & $540,8 \pm 19,2^{b}$ & $10,7 \pm 0,3^{a}$ & $58,0 \pm 0,3^{b}$ & $50,2 \pm 0,5^{b}$ & $65,8 \pm 0,2^{b}$ \\
\hline 6 & 11,0 & 0,03 & $0,6 \pm 0,0^{b}$ & $541,7 \pm 49,1^{b}$ & $10,6 \pm 0,6^{a}$ & $57,8 \pm 0,5^{b}$ & $50,1 \pm 0,9^{b}$ & $65,4 \pm 0,8^{b}$ \\
\hline 7 & 10,0 & 0,08 & $0,6 \pm 0,0^{b}$ & $551,9 \pm 5,0^{b}$ & $11,2 \pm 0,4^{a}$ & $57,5 \pm 0,2^{b}$ & $49,6 \pm 0,2^{b}$ & $65,4 \pm 0,2^{b}$ \\
\hline
\end{tabular}

(1) Grupos 1, 2 e 3 referem-se aos derivados reticulados e os grupos 5, 6 e 7 aos derivados acetilados de amido de mandioca.

* Letras iguais na mesma coluna indicam que não há diferença significativa entre as médias $(p>0,05)$ de acordo com o teste de Games-Howell. 
Observa-se na Tabela 10 que o aumento do pH do meio de reticulação de 10,0 para 11,0 não influenciou nos parâmetros de gelatinização $(p>0,05)$ dos derivados reticulados. Da mesma forma, o aumento da razão molar de trimetafosfato trisódio por unidade de anidroglicose também não influenciou os parâmetros de gelatinização $(p>0,05)$ dos derivados reticulados de amido de mandioca.

Como consequência, os parâmetros de gelatinização dos derivados acetilados do amido de mandioca também não foram influenciados $(p>0,05)$ pelo $\mathrm{pH}$ e pela razão molar de trimetafosfato trisódio por unidade de anidroglicose no meio de reticulação do derivado utilizado para a síntese do seu par acetilado, como pode ser verificado na Tabela 10.

Esses resultados evidenciaram a ausência de grupos fosfato entre as moléculas dos derivados reticulados, apontando para o fato que as moléculas de amido de mandioca não reticularam.

Como pode ser verificado na Tabela 10, a acetilação das moléculas do amido de mandioca influenciou $(p<0,05)$ nos parâmetros de gelatinização dos derivados acetilados.

O máximo valor do sinal de fluxo de calor $(A)$ diminuiu, indicando que uma parcela de energia deixou de contribuir para a transição. A largura à meia altura ( $F W H M$ ) aumentou. Ou seja, a transição durou um intervalo de tempo maior, indicando maior heterogeneidade de componentes no derivado acetilado. A temperatura de gelatinização $\left(T_{\mathrm{m}}\right)$, a temperatura inicial $\left(T_{\mathrm{m}, \mathrm{i}}\right)$ e final $\left(T_{\mathrm{m}, \mathrm{f}}\right)$ da transição diminuíram, indicando o abaixamento do ponto de fusão da amilopectina.

A entalpia de gelatinização $\left(\Delta_{\mathrm{m}} H\right)$ também diminuiu, mas a diferença entre as médias não alcançou significância estatística $(p>0,05)$, como pode ser verificado na Tabela 10.

\subsection{ESTRUTURA MOLECULAR DO AMIDO DE MANDIOCA QUIMICAMENTE MODIFICADO GELATINIZADO}

Os espectros Raman das moléculas gelatinizadas do amido de mandioca reticulado não apontaram a presença de ligações químicas de grupos fosfato, nem evidenciaram mudança no espectro devido à solubilização dos grânulos. Por outro lado, os espectros Raman das moléculas gelatinizadas do amido de mandioca 
acetilado foram desconsiderados por causa da interferência de bandas do material do substrato.

Assim como os espectros de absorção no infravermelho dos derivados reticulados não demonstraram absorção de luz em frequências associadas aos modos vibracionais $\delta_{\text {axial }}(\mathrm{P}=0)$ e $\delta_{\text {axial }}(\mathrm{C}-\mathrm{P}-\mathrm{O})$, os espectros Raman também não indicaram o espalhamento da luz $(\lambda=785 \mathrm{~nm})$ em frequências associadas aos modos vibracionais das ligações nos grupos fosfato, como pode ser visualizado na Figura 41.

Figura 41 - Espectro Raman normalizado das moléculas gelatinizadas e na forma granular do (a) derivado reticulado $\mathrm{R}_{13}\left(\mathrm{pH} 10,0\right.$ e $R_{\text {STMP:AGU }} 0,03$ ), do (b) derivado reticulado $\mathrm{R}_{2}(\mathrm{pH}$ 11,0 e $R_{\text {STMP:AGU }} 0,03$ ), do (c) derivado reticulado $R_{15}\left(\mathrm{pH} 10,0\right.$ e $R_{\text {STMP:AGU }} 0,08$ ) e do (d) derivado reticulado $\mathrm{R}_{16}\left(\mathrm{pH} 11,0\right.$ e $\left.\boldsymbol{R}_{\text {STMP:AGu }} 0,08\right)$.

(a)

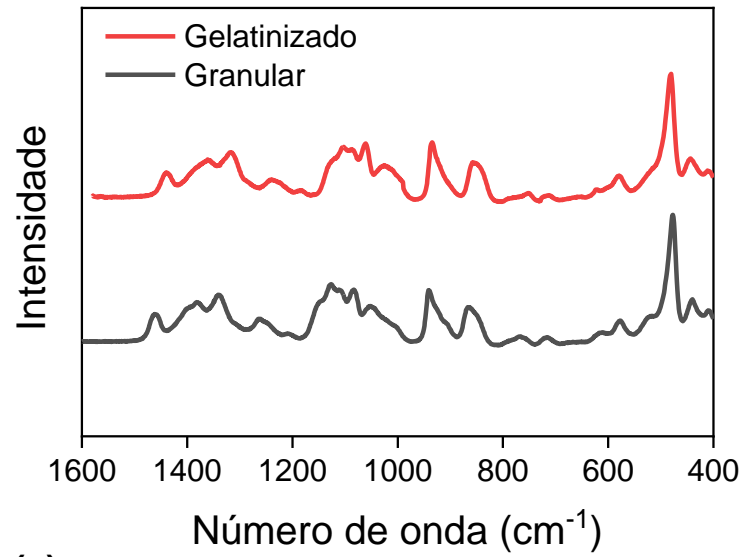

(c)

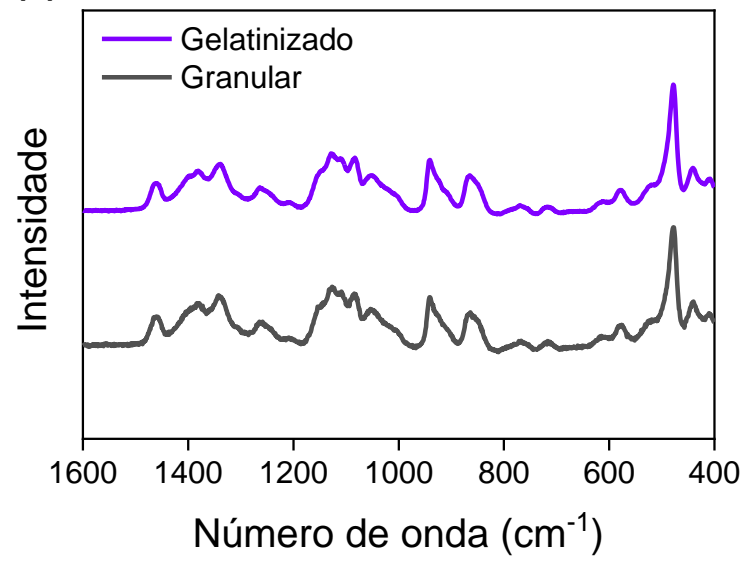

(b)

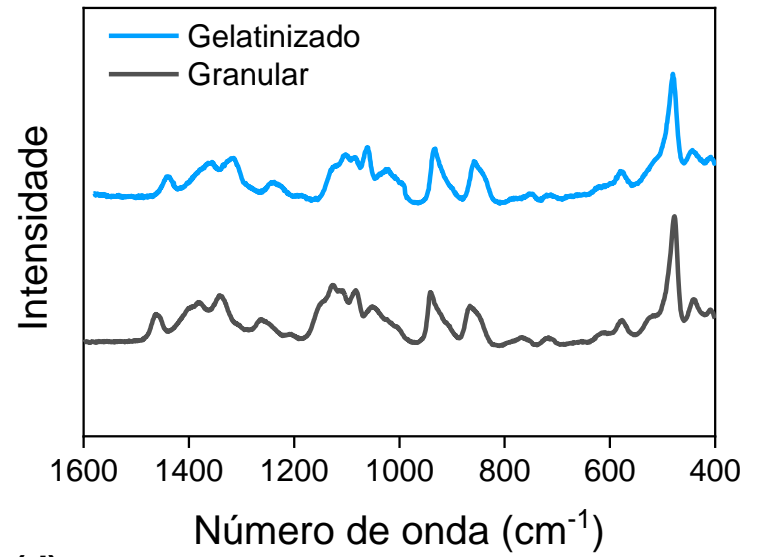

(d)

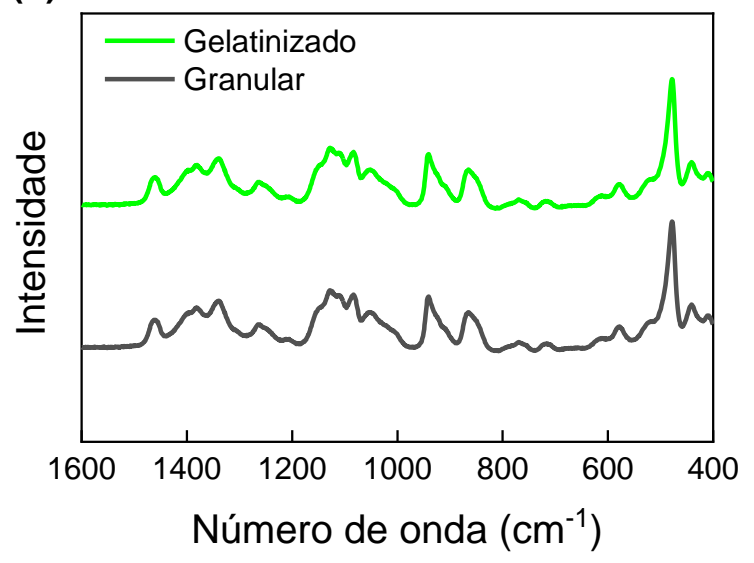

Fonte: Elaborado pela autora (2019).

Observa-se na Figura 41 que as transições estruturais pelas quais as moléculas dos derivados reticulados passaram nos ensaios de microcalorimetria exploratória 
diferencial não afetaram a intensidade Raman das bandas das ligações químicas nas moléculas do amido de mandioca. Ou seja, as bandas do espectro Raman do amido de mandioca foram insensíveis à perda de cristalinidade e à solubilização dos componentes do amido de mandioca na água.

Neste trabalho os resultados de microscopia Raman das moléculas gelatinizadas dos derivados reticulados estão diretamente relacionados aos de microcalorimetria exploratória diferencial, portanto, mais uma evidência de que não houve mudança química nas moléculas do amido de mandioca nas quatro condições de reação estudadas.

Os espectros Raman dos derivados acetilados de amido de mandioca mostraram perda de intensidade de modo que as bandas do poliestireno cristal, o substrato no qual as amostras gelatinizadas foram colocadas, se sobrepuseram às bandas do amido ao longo de todo o espectro e, por isso, não houve resultados. 


\section{DISCUSSÃO}

\subsection{SÍNTESE DO AMIDO DE MANDIOCA QUIMICAMENTE MODIFICADO}

Com base nos resultados, foi possível argumentar que os próprios ânions do trimetafosfato trisódio inibem a formação de ligações cruzadas entre as moléculas do amido e causam o inchamento do grânulo do amido de mandioca a depender das condições de $\mathrm{pH}$ e temperatura do meio de reticulação.

$\mathrm{O}$ pH do meio de reticulação diminui à medida que o intermediário tripolifosfato de sódio enxertado é formado. Este intermediário é o promotor de ligações cruzadas entre as moléculas dos polissacarídeos (LACK et al., 2007).

Woo e Seib (2002) sintetizaram amido de mandioca reticulado com trimetafosfato trisódio na razão molar por unidade de anidroglicose de $0,06, \mathrm{pH} 11,5$, temperatura $45^{\circ} \mathrm{C}$, tempo de reação de $3 \mathrm{~h}$ e na presença de sulfato de sódio $\left(\mathrm{Na}_{2} \mathrm{SO}_{4}\right)$ e de tripolifosfato de sódio $\left(\mathrm{Na}_{5} \mathrm{P}_{3} \mathrm{O}_{10}\right)$, com o intuito de utilizar o derivado como amido resistente. Os pesquisadores argumentam ter registrado queda do $\mathrm{pH}$ do meio de reticulação entre 0,2 a 0,3 , mas não informaram como monitoraram o pH nem apresentaram curvas de variação do $\mathrm{pH}$ ao longo do tempo de reação.

As curvas de variação do $\mathrm{pH}$ do meio de reticulação deste trabalho não indicaram tal diminuição. Os experimentos dos derivados $R_{10}, R_{16}$ e $R_{14}$, todos reticulados à pH 11,0, mostraram variação do $\mathrm{pH}$ de 0,1 (Tabela $6, \mathrm{p} .73$ ).

Isto pode estar associado com o baixo consumo de $\mathrm{NaOH}(\mathrm{aq})$ para formar o tripolifosfato enxertado de amilose e de amilopectina, denotando que a reticulação das moléculas do amido é lenta e a difusão dos ânions $\mathrm{P}_{3} \mathrm{O}_{9}{ }^{3-}(\mathrm{aq})$ do meio de reticulação para o interior do grânulo seja a etapa limitante (LACK et al., 2007).

Alternativamente, isto pode estar associado com o fato que o $\mathrm{NaOH}(\mathrm{aq})$ estava em excesso em relação ao trimetafosfato trisódio nas quatro condições de reação estudadas e, nessas circunstâncias, as moléculas do reagente foram degradadas a tripolifosfato de sódio sem promover a reticulação das moléculas do amido (LACK et al., 2007).

Neste cenário, os grânulos do amido estão hidratados, reversivelmente inchados com carga negativa e na presença dos íons $\mathrm{H}_{3} \mathrm{O}^{+}(\mathrm{aq}), \mathrm{OH}^{-}(\mathrm{aq}), \mathrm{Na}^{+}(\mathrm{aq})$, $\mathrm{P}_{3} \mathrm{O}_{9}{ }^{3-}(\mathrm{aq}), \mathrm{P}_{2} \mathrm{O}_{7}{ }^{4-}(\mathrm{aq})$ e $\mathrm{P}_{3} \mathrm{O}_{10}{ }^{5-}(\mathrm{aq})$ ao longo de $5 \mathrm{~h}$ (LACK et al., 2007). Quanto 
mais alcalino estiver o meio de reticulação, maior quantidade de íons $\mathrm{H}_{3} \mathrm{O}^{+}(\mathrm{aq})$ migrarão das moléculas do amido para a suspensão devido à diferença de concentração, aumentando a densidade de carga negativa nas moléculas do amido (OOSTEN, 1982; OOSTEN, 1990).

Isso dificulta a difusão dos ânions $\mathrm{P}_{3} \mathrm{O}_{9}{ }^{3-}(\mathrm{aq})$ para o interior do grânulo por causa da ação de forças eletrostáticas de repulsão, os ânions $\mathrm{P}_{2} \mathrm{O}_{7}{ }^{4-}(\mathrm{aq})$ e $\mathrm{P}_{3} \mathrm{O}_{10}{ }^{5-}$ (aq) aumentam também a densidade de carga negativa no meio de reação e eles podem ter se distribuído ao redor dos grânulos, dificultando ainda mais a difusão dos ânions $\mathrm{P}_{3} \mathrm{O}_{9}{ }^{3-}(\mathrm{aq})$ (JANE, 1993).

Wongsagonsup et al. (2014) sintetizaram amido de mandioca reticulado na razão molar de trimetafosfato trisódio por unidade anidroglicose de 0,001 a $0,03, \mathrm{pH}$ 11,0 , temperatura de $45^{\circ} \mathrm{C}$ e tempo de reação de $3 \mathrm{~h}$, com o propósito de utilizar o derivado em fórmulas de sopas prontas.

Os autores mostraram, por termogravimetria, que o teor de fósforo nos derivados reticulados de amido de mandioca aumentou, sendo a diferença máxima entre o amido reticulado de mandioca ( $R_{\mathrm{STMP}: A G U}=0,03$ ) e o amido de mandioca nativo de $0,026 \%$. Contudo, tal resultado sozinho não é evidência de ligação cruzada nas moléculas do amido de mandioca. Ele facilmente pode revelar a presença de monoésteres de fosfato ou de sais de fosfato que se formam no meio de reticulação e que não foram removidos na lavagem do derivado.

Além da hipótese de ausência de reticulação das moléculas do amido, os grânulos do derivado reticulado na razão molar de 0,08 e pH 11,0 incharam na etapa de lavagem como consequência das interações dos ânions $\mathrm{P}_{3} \mathrm{O}_{9}{ }^{3-}(\mathrm{aq}), \mathrm{P}_{2} \mathrm{O}_{7}{ }^{4-}(\mathrm{aq}) \mathrm{e}$ $\mathrm{P}_{3} \mathrm{O}_{10}{ }^{5-}(\mathrm{aq})$ com as moléculas do amido de mandioca (GOUGH, PHYBUS, 1973). Essa hipótese do inchamento dos grânulos de $\mathrm{R}_{4}$ (dois experimentos de síntese), $\mathrm{R}_{8}$ e $R_{16}$ (dois experimentos de síntese) explicaria porque não foi possível recuperar esses derivados por filtração na lavagem.

Woo e Seib (2002) recuperaram o amido de mandioca reticulados na etapa de lavagem por centrifugação, isto é, o inchamento dos grânulos do derivado não seria prontamente percebido. Já Wongsagonsup et al. (2014) não especificaram se os derivados de amido de mandioca foram recuperados por filtração ou por centrifugação e não mencionaram problemas, que poderiam ser atribuídos ao inchamento.

Partindo da suposição de excesso de cargas negativas no grânulo e no meio de reticulação, as moléculas do amido nas camadas mais externas se deformaram no 
interior dos grânulos, contudo eles não incharam por causa da presença dos íons $\mathrm{Na}^{+}$(aq) que geraram forças eletrostáticas de atração, as quais mantiveram a estrutura do grânulo unida. Entretanto, conforme os grânulos foram sendo lavados, os íons foram sendo removidos e quando as forças eletrostáticas de atração ficaram fracas os grânulos incharam, impedindo a filtração (JANE, 1993; GOUGH; PHYBUS, 1973).

As moléculas desses derivados também podem ter gelatinizado. Oosten (1982) propôs que os ânions seriam os verdadeiros agentes do inchamento e da gelatinização. Eles desestabilizam as ligações intramoleculares de hidrogênio da água nos cristais de amilopectina e isso aumenta a mobilidade das moléculas de água e facilita as hélices duplas de amilopectina se desprenderem do conjunto cristalino (JANE, 1993; LECHERT, 1981). Os ânions $\mathrm{P}_{3} \mathrm{O}_{10}{ }^{5-}(\mathrm{aq})$ aumentam a densidade de carga negativa no meio de reticulação de modo que enfraquecem as ligações de hidrogênio das moléculas de água nos cristais de amilopectina e desencadeam a gelatinização.

Se os grânulos tivessem sido observados ao longo do experimento de síntese e das etapas de purificação em um microscópio óptico de luz polarizada, a perda do sinal de birrefringência teria sido constatada e haveria evidência para o inchamento do grânulo e a gelatinização das moléculas do amido de mandioca.

Os resultados deste trabalho sugerem que, a depender da concentração, 0 trimetafosfato trisódio $\left(\sim 0,1 \mathrm{~mol} \mathrm{~L}^{-1}\right)$ desestabiliza os grânulos do amido de mandioca nativo em supensões à $\mathrm{pH}$ próximo de 11,0 e a temperatura de $50^{\circ} \mathrm{C}$. O efeito dessa desestabilização pode não ser necessariamente percebido durante a síntese, ele pode se manifestar nas etapas subsequentes.

Como os efeitos das interações iônicas sobre o comportamento de inchamento e de gelatinização dependem da concentração e da densidade de carga, a força iônica $(\mu)$

$$
\mu=\frac{1}{2} \times \sum_{i}^{n} c_{i} \times z_{i}^{2}
$$

seria um parâmetro prático na definição das condições de reticulação de amidos com trimetafosfato trisódio porque no seu cálculo são consideradas a concentração de cada íon ( $\left.c_{i}\right)$ e a contribuição de sua carga $\left(z_{i}\right)$. 
Com base no que foi discutido, o derivado $R_{16}$ foi descartado como resultado porque sua síntese foi ao acaso; um sucesso em cinco tentativas. De qualquer modo, este derivado foi acetilado e caracterizado assim como os demais.

Sem uma parte dos derivados, a matriz dos experimentos de síntese dos derivados reticulados de amido de mandioca foi reduzida de 16 para nove derivados, como mostra a Tabela 11.

Tabela 11 - Matriz final dos experimentos de síntese dos derivados reticulados de amido de mandioca, com os respectivos pH de reação e razão molar de trimetafosfato trisódio por unidade de anidroglicose

\begin{tabular}{|c|c|c|c|}
\hline \multicolumn{3}{|c|}{ Derivados por condição de reação } & Tamanho amostra \\
\hline \multirow[b]{2}{*}{$\mathrm{pH}$} & \multicolumn{2}{|c|}{$R_{S T M P: A G U}$} & $\mathrm{~N}$ \\
\hline & 0,03 & 0,08 & Total \\
\hline 10,0 & $\mathrm{R}_{1} ; \mathrm{R}_{5} ; \mathrm{R}_{9}$ e $\mathrm{R}_{13}$ & $R_{7} ; R_{11}$ e $R_{15}$ & 7 \\
\hline 11,0 & $R_{2}$ e $R_{10}$ & - & 2 \\
\hline Total & 6 & 3 & 9 \\
\hline
\end{tabular}

Fonte: Elaborado pela autora (2019).

O derivado $R_{14}$ foi excluído da matriz final de experimentos porque ele foi acidentalmente contaminado durante a execução dos ensaios de determinação do teor de umidade.

Por tudo isso, não se pôde diferenciar o efeito do aumento da quantidade de trimetafosfato trisódio do efeito do $\mathrm{pH}$ sobre os parâmetros de gelatinização do amido de mandioca reticulado. Uma análise de variância fatorial não faria sentido para uma matriz de experimentos cujo número de amostras a pH 11,0 é duas vezes menor que o número de amostras reticuladas a pH 10,0, sendo que a maior parte das amostras neste $\mathrm{pH}$ foram sintetizadas na menor proporção de trimetafosfato trisódio (Tabela 11).

Precaução deve ser tomada ao definir as proporções de trimetafosfato trisódio, os limites de pH e de temperatura de reação para que as moléculas do amido não se desestabilizem, rompendo o grânulo ou que impeça a difusão dos ânions fosfato para o interior do grânulo, prevenindo a reticulação das moléculas do amido. 
A integridade dos grânulos de amido tem de ser garantida desde a síntese até o momento do uso do produto, tendo em vista que o inchamento e a gelatinização inesperados dos grânulos normalmente comprometem a utilidade do produto. Por isso, as implicações das moléculas do amido estarem confinadas no grânulo e das interações íons-moléculas de amido desencadearem a gelatinização devem ser consideradas para definir a abordagem experimental e as condições de reação que assegurem a integridade do grânulo e a eficácia do processo de modificação química.

O sistema de controle do pH não foi exato, por isso, o pH do meio de acetilação não convergiu para o valor de referência, mas o sistema atendeu ao propósito de manter o meio de reação alcalino e em condições seguras ao grânulo do amido de mandioca. Se o ajuste do $\mathrm{pH}$ tivesse sido feito manualmente seria alta a probabilidade de perder os derivados por descontrole do $\mathrm{pH}$ e de sintetizar derivados em condições diferentes, prejudicando a comparação dos resultados e a credibilidade das conclusões deste trabalho (VAUX; FIDLER; CUMMING, 2012).

Curvas de consumo de $\mathrm{NaOH}(\mathrm{aq})$ a 3,0 $\mathrm{mol} \mathrm{L}^{-1}$ do sistema de acetilação sem e com amido de mandioca nativo estão mostradas na Figura 42. Estas curvas foram adquiridas usando o sistema de controle de $\mathrm{pH}$ aprimorado com dosagem de $\mathrm{NaOH}($ aq) via seringa (Figura 13, p. 59). 
Figura 42 - Relação entre os volumes gastos de $\mathrm{NaOH}(\mathrm{aq})$ a 3,0 $\mathrm{mol} \mathrm{L}^{-1}$ para manter o meio de acetilação alcalino próximo de 10,0 do (a) sistema de reação sem amido de mandioca nativo e do (b) sistema de reação com amido de mandioca nativo.

(a)

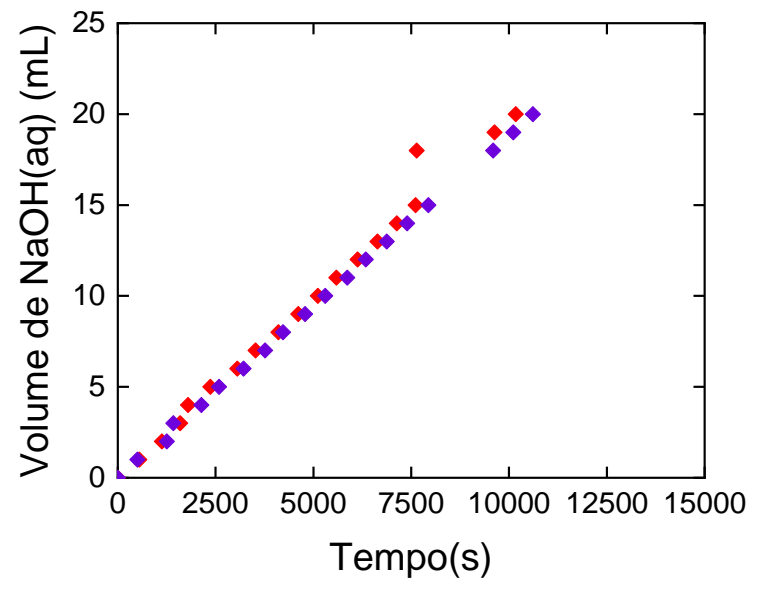

(b)

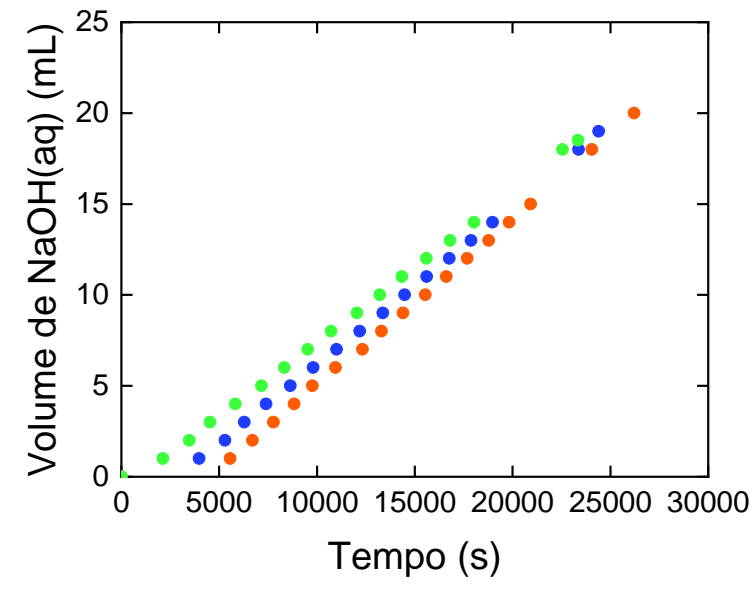

Fonte: Elaborado pela autora (2019).

A reação de acetilação do amido em meio aquoso é a neutralização do ácido e, secundariamente, forma o acetato de amido. As curvas de consumo de $\mathrm{NaOH}(\mathrm{aq})$ da Figura 42 evidenciam o potencial do dano que a hidrólise ácida pode causar ao grânulo por meio da quantidade de ácido acético gerado.

A presença dos grânulos de amido de mandioca diminui a taxa de consumo de $\mathrm{NaOH}(\mathrm{aq})$. A inclinação das curvas da Figura 42 (b) foi menor que a inclinação das curvas na Figura 42 (a) porque uma parte das moléculas do anidrido acético formaram acetato com as moléculas do amido. Entretanto, a proporção é pequena e a formação do ácido acético prevalece, o qual pode tamponar o meio de acetilação e degradar os grânulos se não for rapidamente neutralizado.

Com base nisso, é possível identificar que a vazão da solução de $\mathrm{NaOH}(a q)$ poderia ser usada para o acompanhamento indireto do progresso da reação e, desta forma, estabelecer o instante em que a adição de anidrido acético poderia ser encerrada. Entretanto, isto requerirá um projeto com a integração mecânica de cada sistema à montagem experimental.

Os estudos disponíveis não discorrem sobre o fato de que a neutralização inadequada do ácido acético causaria a hidrólise das moléculas do amido e que a adição exagerada do $\mathrm{NaOH}(\mathrm{aq})$ causaria a gelatinização. Além disto, os autores constatam que os grânulos dos derivados erodiram ou se aglutinaram, mas não correlacionam essas evidências às condições em que o derivado foi sintetizado 
(GOLACHOWSKI et al., 2015; HUANG et al., 2006; HUNG; MORITA, 2005; SINGH; CHAWLA; SINGH, 2004; SINGH; KAUR; MCCARTHY, 2007; WURZBURG, 1986).

Não foi possível encontrar na literatura curvas de $\mathrm{pH}$ ao longo do tempo de sistemas de acetilação de amido, apesar da abundância de trabalhos sobre a acetilação de diversos tipos de amidos para aplicações nas indústrias alimentícia e biomédica.

\subsection{ESTRUTURA MOLECULAR DO AMIDO DE MANDIOCA QUIMICAMENTE MODIFICADO GRANULAR}

Os espectros vibracionais no infravermelho dos derivados reticulados de amido de mandioca não demonstraram modificação química das moléculas do amido no grânulo e fortaleceram a hipótese que as moléculas do amido não reticulam nas condições de reação estudadas. Já os espectros vibracionais no infravermelho dos derivados acetilados de amido de mandioca, além da presença de grupos acetila nas moléculas do amido, demonstraram a presença de moléculas de ácido acético na estrutura do grânulo.

Mesmo que a deconvolução dos espectros no infravermelho dos derivados reticulados do amido de mandioca não tenham indicado absorção em frequências associadas com os modos de vibração das ligações no grupo fosfato, essas bandas podem estar sobrepostas e ocultas por outras mais intensas.

Isto ocorre quando poucos grupos fosfato são inseridos nas moléculas do amido, ou quando as moléculas modificadas estão localizadas em regiões fora do alcance da luz infravermelha (ASTM, 2013; WARREN et al., 2013).

Porém, a hipótese de que não houve reticulação tem evidência experimental. Aguiar (2014) empregou a técnica de transmissão para avaliar a estrutura molecular de derivados reticulados de amido de mandioca no infravermelho. A autora avaliou estrutura molecular dos derivados reticulados com maior quantidade de trimetafosfato trisódio (RSTMP:AGu de 0 a $0,16, \mathrm{pH} 11,0$, temperatura de $50^{\circ} \mathrm{C}$ e tempo de reação de $5 \mathrm{~h}$ ) em comparação a deste trabalho e os resultados também não indicaram a presença de grupos fosfato na moléculas do amido.

Os demais estudos sobre amido de mandioca reticulado com trimetafosfato trisódio avaliados não empregaram técnicas espectroscópicas para caracterizar a 
estrutura molecular do amido de mandioca modificado (KASEMSUWAN; BAILEY; JANE, 1998; WONGSAGONSUP et al., 2014; WOO; SEIB, 1997; WOO; SEIB, 2002).

Com base nos resultados dos experimentos de síntese dos derivados reticulados de amido de mandioca e nos resultados de espectroscopia no infravermelho deste trabalho e do de Aguiar (2014), a hipótese de que não houve reticulação das moléculas do amido é plausível.

Mais, é possível supor que o tripolifosfato de sódio não foi enxertado nas moléculas do amido e, por isso, a ligação cruzada não ocorreu nem houve a formação de monoésteres (LACK et al., 2007). Para o tripolifosfato de sódio enxertado se formar, os ânions $\mathrm{P}_{3} \mathrm{O}_{9}^{3-}(\mathrm{aq})$ precisam difundir do meio de reação para o interior do grânulo e isso não ocorreu.

Os resultados de espectroscopia no infravermelho confirmaram a presença dos grupos acetila $\left(\mathrm{CH}_{3} \mathrm{CO}-\right)$ nas moléculas do amido e indicaram a presença de moléculas de ácido acético no interior do grânulo do amido de mandioca.

Huang et al. (2006) acetilaram o amido de feijão verde com acetato de vinila ou com anidrido acético na mesma razão de $0,088 \mathrm{~mol}$ de agente acetilante por mol de unidade de anidroglicose e compararam o padrão de substituição dos grupos hidroxilas nas moléculas dos dois derivados. Os autores demonstraram que as moléculas de amilopectina apresentaram cerca de $45 \%$ dos grupos acetila do total inserido nas moléculas do amido e que os grupos acetila se distribuíram mais uniformemente nas moléculas do amido de feijão quando acetiladas com anidrido acético.

Com base nos resultados acima, os grupos acetila inseridos nas unidades de anidroglicose fazem das moléculas modificadas unidades copolimerizadas, como se tivessem sido formadas por mais um monômero.

Sabendo que apenas as moléculas de amilopectina localizadas nas regiões amorfas das camadas de crescimento são modificadas, as unidades copolimerizadas aí formadas estão sujeitas à hidrólise pelo ácido acético e as moléculas hidrolisadas dessas unidades atuam como contaminantes no grânulo (BERTOFT et al., 2010; BERTOFT, 2013; FLORY, 1953). 


\subsection{PARÂMETROS DE GELATINIZAÇÃO DO AMIDO DE MANDIOCA QUIMICAMENTE MODIFICADO}

Os resultados de microcalorimetria exploratória diferencial e os de espectroscopia no infravermelho se conciliaram e reforçaram a hipótese que os ânions fosfato $\mathrm{P}_{3} \mathrm{O}_{9}{ }^{3-}, \mathrm{P}_{2} \mathrm{O}_{7}{ }^{4-}$ e $\mathrm{P}_{3} \mathrm{O}_{10}{ }^{5-}$ inibem a reticulação das moléculas do amido de mandioca.

As causas para a falta de grupos fosfato nas moléculas do amido de mandioca poderiam ser o tempo de reação insuficiente e os íons não alcançaram as moléculas suscetíveis à reticulação, ou a movimentação dos íons no meio de reticulação foi tal que eletrostaticamente blindou os grânulos, repelindo os ânions $\mathrm{OH}^{-}(\mathrm{aq}), \mathrm{P}_{3} \mathrm{O}_{9}{ }^{3-}(\mathrm{aq})$, $\mathrm{P}_{2} \mathrm{O}_{7}{ }^{4-}(\mathrm{aq})$ e $\mathrm{P}_{3} \mathrm{O}_{10}{ }^{5-}(\mathrm{aq})$.

A segunda causa é a mais coerente com os resultados deste trabalho porque os grânulos dos derivados reticulados no $\mathrm{pH} 11,0$ e razão molar de reagentes 0,08 se desestabilizaram quando eles foram recuperados do meio de reticulação e lavados.

Woo e Seib (2002) também analisaram os derivados reticulados por calorimetria exploratória diferencial nas seguintes condições: razão em massa de amido e de água $1: 4$, faixa de temperatura de 20 a $120^{\circ} \mathrm{C}$ e taxa de aquecimento de $10^{\circ} \mathrm{C} \mathrm{min}^{-1}$.

Os pesquisadores não apresentaram os resultados da análise para o amido de mandioca. A temperatura de gelatinização dos derivados reticulados de amido de trigo, trigo ceroso, milho, milho ceroso e batata $(60,9 ; 66,9 ; 69,6 ; 73,6$ e 59,4$){ }^{\circ} \mathrm{C}$ aumentou quando comparada a temperatura de gelatinização de um branco $(56,6$; $60,0 ; 64,3 ; 65,2$ e 57,3$)^{\circ} \mathrm{C}$ e isso foi atribuído às ligações cruzadas nas moléculas do amido.

A entalpia de gelatinização dos derivados reticulados $(8,9 ; 12,2 ; 10,5 ; 12,4$; 12,3) $\mathrm{J} \mathrm{g}^{-1}$ diminuiu quando comparada com a do branco $(9,8 ; 13,1 ; 11,9 ; 15,7$; $11,6) \mathrm{J} \mathrm{g}^{-1}$. Neste caso, os autores explicaram que houve annealing do grânulo de amido ao longo do tempo de reação e, por tanto, a entalpia de gelatinização diminuiu.

Esses resultados não confirmaram nem esclareceram os resultados deste trabalho para o amido de mandioca. $\mathrm{O}$ annealing promove $\mathrm{o}$ reordenamento $\mathrm{e}$ recristalização das hélices duplas de amilopectina e isto aumenta a entalpia de gelatinização de acordo com o estudo de Vamadevan et al. (2013). Além disso, o 
tempo de $3 \mathrm{~h}$ ou de $5 \mathrm{~h}$ não seria suficiente para promover tal reorganização dos cristais de amilopectina no amido de mandioca (BILIADERIS, 2009; VAMADEVAN et al., 2013)

No estudo de Wongsagonsup et al. (2014), os pesquisadores caracterizaram os derivados reticulados por calorimetria exploratória diferencial nas seguintes condições: razão em massa de amido e de água 1:3, faixa de temperatura de 25 a $100{ }^{\circ} \mathrm{C}$ e taxa de aquecimento de $10^{\circ} \mathrm{C} \mathrm{min}^{-1}$.

Os pesquisadores mostraram que a temperatura de gelatinização dos derivados reticulados de amido de mandioca foi insensível à variação da quantidade de trimetafosfato trisódio o que condiz com os resultados deste trabalho.

Nas condições estudadas por Wongsagonsup et al. (2014), a entalpia de gelatinização dos derivados reticulados de amido de mandioca aumentou, à medida que a quantidade de trimetafosfato trisódio foi maior no meio de reticulação o que foi atribuído à presença de ligações cruzadas nas moléculas do amido de mandioca.

Entretanto, essa explicação não tem evidência que mostre os grupos fosfato na estrutura molecular dos derivados e é contestada pelo fato de que as ligações cruzadas ocorrem nas regiões amorfas do grânulo entre as moléculas de amilose e amilopectina (KASEMSUWAN; JANE, 1994; JANE, 2009). O efeito direto disso, na realidade, é o aumento das temperaturas da transição, visto que o inchamento do grânulo é inibido pelas ligações cruzadas, que são covalentes (SINGH; KAUR; MACCARTHY, 2006).

À parte as diferenças nos resultados devido às condições de ensaio, os resultados de Woo e Seib (2002) e de Wongsagousung et al. (2014) não se conciliaram com os deste trabalho e a hipótese de que as moléculas do amido de mandioca não reticularam ainda é plausível.

Múltiplas transições endotérmicas ocorrem quando suspensões de amido são aquecidas até $150^{\circ} \mathrm{C}$. Não há consenso, mas as transições abaixo de $100^{\circ} \mathrm{C}$ estariam relacionadas à fusão dos cristais de amilopectina (BILIADERIS, 2009). Com base nisso e levando em consideração a natureza semicristalina do grânulo, é plausível supor que a transição endotérmica $\left(\mathrm{M}_{2}\right)$ corresponda à fusão de cristais de amilopectina mais estáveis (FLORY, 1953).

Esses cristais se recristalizaram ao longo do ensaio de microcalorimetria exploratória diferencial, a recristalização pode ocorrer quando o grânulo é lentamente aquecido na presença de água. Nestas condições, as regiões amorfas hidratadas 
aumentam de volume e os cristais menos estáveis de amilopectina se fundem, aliviando tensões na rede cristalina onde os cristais remanescentes têm as condições para se recristalizarem, tornando-se mais estáveis e fundindo a temperatura maior (FLORY,1953).

Outra explicação para a natureza da transição $M_{2}$ seria a de que se trata de uma transição reversível de fase de cristal líquido (BILIADERIS, 2009; FLORY, 1984; RANDZIO et al., 2002). Se a etapa de resfriamento tivesse sido realizada à taxa de $1,0^{\circ} \mathrm{C} \mathrm{min}^{-1}$, igual à taxa de aquecimento, a curva de resfriamento poderia ter sido usada para confirmar a natureza de $\mathrm{M}_{2}$.

As transições $L_{1}$ e $L_{2}$ podem ser acomodações das hélices de amilopectina e de amilose entre fases de cristal líquido (FLORY, 1984). Isso é possível porque o sistema amido-água deste trabalho foi lentamente aquecido e tinha a proporção de amido e água (1:3) que favorecia à formação de coloide-sol após a solubilização dos componentes do grânulo (FISCH; KUMAR, 2001; FLORY, 1984; NEUBERT; 2001; RANDZIO et al., 2002).

As moléculas de amilopectina, que estão em maior quantidade, são as que comandam essas transições de fase. Os cristais de amilopectina vagarosamente se soltam da rede cristalina, as hélices continuam emparelhadas e assim se dispersam na água voltadas para uma mesma direção e com mesmo ângulo em relação ao eixo dessa direção principal. Dessa forma, vários agrupamentos organizados de hélices duplas formam uma fase e o sistema exibe comportamento de cristal líquido (FISCH; KUMAR, 2001; FLORY, 1984).

Essa fase é que teria passado pelas transições $L_{1}$ e $L_{2}$ (Smética $\rightarrow$ nemática $\rightarrow$ isotrópica) até as hélices completamente se desorganizarem. Reiterando, a curva de resfriamento do sistema poderia ter ajudado a esclarecer se essas transições de fase ocorreram (FISCH; KUMAR, 2001; NEUBERT; 2001).

Em relação ao tratamento dos dados de microcalorimetria exploratória diferencial, num primeiro momento, a deconvolução do sinal de fluxo de calor seria a estratégia mais adequada para maximizar a sensibilidade do calorímetro e estimar os parâmetros térmicos do fenômeno de fusão dos cristais de amilopectina.

A motivação para essa abordagem baseou-se nas evidências experimentais de que o pico de gelatinização é uma transição de energia de um evento médio entre a 
fusão dos cristais de amilopectina e o desemparelhamento das hélices recémliberadas da rede cristalina (BILIADERIS, 2009; PÉREZ; BALDWIN; GALLANT, 2009).

A fusão seria o evento que mais contribui para a transição e a contribuição do desemparelhamento das hélices estaria oculta. A intenção foi separa-los, deconvoluindo o pico de gelatinização com duas funções gaussianas. Sem a pretensão de descrever matematicamente os fenômenos, a escolha do tipo de função foi arbitrária e levou apenas em consideração o formato de sino que as transições de energia nas curvas de calorimetria exploratória diferencial normalmente assumem.

Entretanto, na prática, essa abordagem levou a uma manipulação excessiva dos dados durante o tratamento em um esforço de padronizar as curvas de microcalorimetria exploratória diferencial para o ajuste das funções gaussianas. Apesar dos detalhes nas transições que a microcalorimetria exploratória diferencial oferece, o tratamento dos dados pode impor limitações ao uso da técnica.

As condições do meio de reticulação não influenciaram os parâmetros térmicos de gelatinização dos derivados acetilados do amido de mandioca. Isto pode ser explicado, assumindo que os grupos acetila ligaram-se às moléculas das camadas mais externas do grânulo e que os grupos fosfato estariam ligados às moléculas das camadas mais internas e, por isso, não influenciaram na acetilação das moléculas dos derivados reticulados (HUNG; MORITA, 2005; SINGH; KAUR; MCCARTHY, 2006).

A explicação alternativa é que não havia grupos fosfato nas moléculas dos derivados reticulados e, por isso, a acetilação afetou igualmente os parâmetros térmicos de gelatinização dos derivados acetilados de amido de mandioca.

Isto é outro fato associado com a ausência de ligações cruzadas nas moléculas do amido de mandioca reticulado, visto que as moléculas sujeitas à reticulação seriam as mesmas a receber os grupos acetila. Nesta situação, os grupos fosfato dificultariam a entrada dos grupos acetila, interferindo no padrão e na razão molar de substituição dos derivados acetilados (HUNG; MORITA, 2005; SINGH; KAUR; MCCARTHY, 2006).

A acetilação das moléculas do amido de mandioca diminuiu a estabilidade térmica dos grânulos devido ao abaixamento do ponto de fusão dos cristais de amilopectina causado pela presença de moléculas de amido hidrolisadas na fase fundida (BILIADERIS, 2009; COOKE; GIDLEY, 1992; FLORY, 1953). 
Por isso, o pico de gelatinização apresentou-se mais largo, em comparação ao pico de gelatinização dos derivados reticulados, abriu e avançou para valores menores de temperatura.

Do ponto de vista físico, o aumento do tempo de gelatinização revelou novas interações entre o componente (hélice de amilopectina) envolvido diretamente com a transição e os novos componentes (moléculas hidrolisadas) na fase fundida. As moléculas hidrolisadas com grupos acetila agiriam como se fossem unidades copolimerizadas, isto é, impurezas no interior do grânulo (FLORY, 1953).

Essa hipótese está alinhada com os resultados de espectroscopia no infravermelho que apontaram para a presença de grupos acetila nas moléculas do amido e de ácido acético no interior dos grânulos.

A queda de intensidade do sinal de fluxo de calor revelou que uma parcela de energia deixou de contribuir para a transição. Como as moléculas de amilopectina das regiões cristalinas não são modificadas na acetilação, a contribuição do calor latente de fusão dos cristais de amilopectina não mudaria.

Parte da energia liberada no desemparelhamento das hélices de amilopectina pode ter deixado de contribuir para a transição; o desemparelhamento foi facilitado (BILIADERIS; 2009; COOKE; GIDLEY, 1992). As cadeias-backbone interconectam as hélices dos arranjos cristalinos, formando uma rede que está imersa nas áreas armorfas das camadas de crescimento e sujeita a interagir com reagentes, diluentes e impurezas que se difundem pelo grânulo (BERTOFT et al., 2010; BERTOFT, 2013; LAOHPHATANALEART et al., 2010).

O ácido acético pode ter hidrolisado as cadeias-backbone durante os experimentos de microcalorimetria exploratória diferencial. Se for fato que as cadeias- backbone hidrolisaram, as hélices de amilopectina se desorganizaram com maior facilidade e, como os ácidos aleatoriamente quebram as moléculas do amido, a heterogeneidade de componentes na fase fundida aumentou.

Os resultados evidenciaram a ausência de reticulação das moléculas dos derivados de amido de mandioca e levantou-se a hipótese de que a causa da menor estabilidade térmica dos derivados acetilados de amido de mandioca pode ser a presença de moléculas hidrolisadas na fase fundida da amilopectina, levando ao abaixamento do ponto de fusão. 


\subsection{ESTRUTURA MOLECULAR DO AMIDO DE MANDIOCA QUIMICAMENTE MODIFICADO GELATINIZADO}

Os espectros Raman confirmaram a inexistência de ligações covalentes cruzadas nas moléculas do amido de mandioca reticulado, corroborando os resultados de microcalorimetria exploratória diferencial. As transições estruturais, marcadas pela quebra de ligações de hidrogênio, das moléculas do amido de mandioca reticulado na gelatinização não alteraram o perfil do espectro Raman em relação ao contraparte granular, no qual as moléculas do amido estão organizadas no grânulo.

As amostras após os experimentos de microcalorimetria diferencial estavam gelificadas e com algum grau de organização das moléculas do amido, como mostram as curvas de microcalorimentria exploratória diferencial no resfriamento dos derivados $R_{13}, R_{2}, R_{15}$ e $R_{16}$ na Figura 43.

Figura 43 - Curva de $\mu \mathrm{DSC}$ com a linha de base corrigida no resfriamento do (a) derivado $\mathrm{R}_{13}$ (pH 10,0 e $R_{\text {StMP:AGU }}$ 0,03), do (b) derivado $\mathrm{R}_{2}$ (pH 11,0 e $R_{\text {STMP:AGU }} 0,03$ ), do (c) derivado $R_{15}\left(\mathrm{pH} 10,0\right.$ e $R_{\text {StMP:AGU }} 0,08$ ) e do (d) derivado $R_{16}\left(\mathrm{pH} 11,0\right.$ e $\left.R_{\text {StMP:AGU }} 0,08\right)$.

(a)

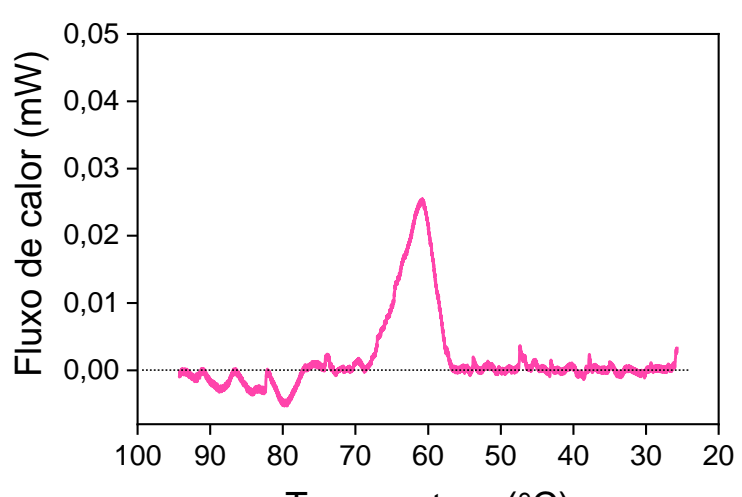

(c)

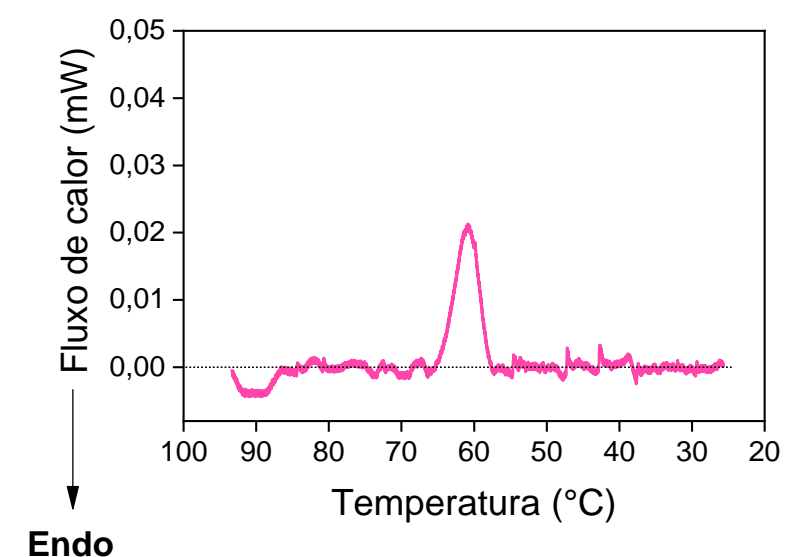

(b)

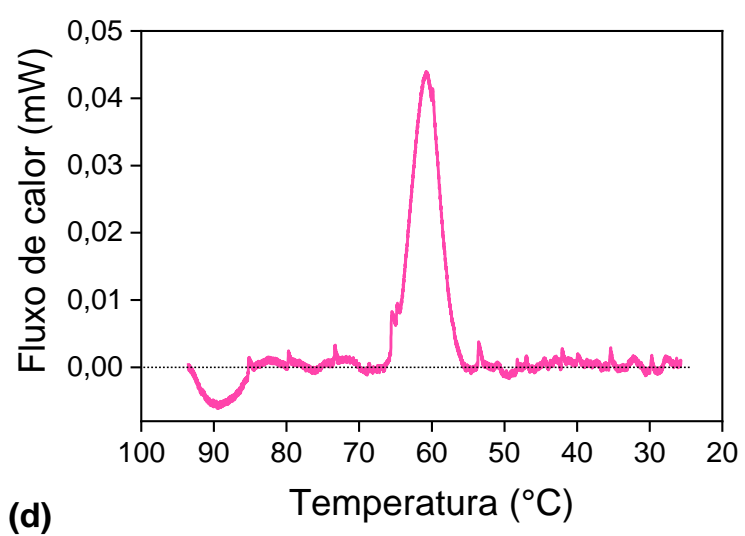

(d)

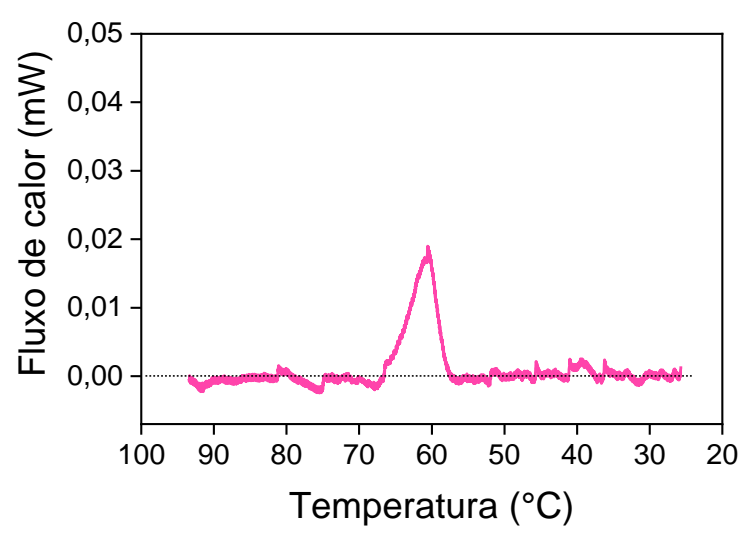

Fonte: Elaborado pela autora (2019). 
Observa-se na Figura 43 que as curvas de microcalorimentria exploratória diferencial do resfriamento evidenciaram uma transição exotérmica entre 50 e $70{ }^{\circ} \mathrm{C}$ com valor máximo de fluxo de calor próximo de $61^{\circ} \mathrm{C}$.

Esta transição está associada com o reordenamento ou recristalização das moléculas do amido de mandioca e demonstra que o sistema no aquecimento tornouse de fato um sol e as condições do resfriamento o levou de sol para gel (BILIADERIS, 2009; FLORY, 1984).

Trata-se de uma inconsistência nas análises, as amostras não estavam amorfas. De qualquer forma, não inválida os resultados, visto que a quantidade de cristais formados no resfriamento não ocultaria uma alteração no espectro causada pela fusão dos cristais de amilopectina.

O alinhamento dos resultados de espectroscopia no infravermelho, de microcalorimetria diferencial e de microscopia Raman permite argumentar que as moléculas do amido de mandioca não se reticularam nas condições de reação estudadas.

Uma forma de comprovar isso seria analisar a distribuição da massa molecular das moléculas de amilopectina dos derivados reticulados por cromatografia de permeação em gel. $O$ aumento da massa molecular revelaria se as moléculas de amilose se reticularam às de amilopectina e daria uma noção relativa da densidade de ligação cruzada (JANE; XU; RADOSAVLJEVIC;SEIB, 1992; KASEMSUWAN; JANE, 1994).

A indústria e a academia lançam mão de ensaios reológicos nos quais curvas da razão entre o módulo dinâmico de armazenamento e o módulo de perda em função da frequência de oscilação qualitativamente informam a presença de ligações cruzadas no amido (DULONG et al., 2011; KASEMSUWAN; JANE, 1994; KASEMSUWAN; BAILEY; JANE, 1998; WONGSAGONSUP et al., 2014; WURZBURG, 1986).

O problema é que usar uma propriedade macroscópica para comprovar ou identificar alteração da estrutura molecular nos grânulos pode levar a conclusões equivocadas. ĺons de sais não removidos durante a lavagem dos grânulos do derivado reticulado com trimetafosfato trisódio, por exemplo, podem interferir nas análises das moléculas solubilizadas, porque geram forças eletrostáticas de atração, e isso pode ser equivocadamente atribuído à presença de ligações cruzadas. 
Os espectros Raman dos derivados acetilados sofreram interferência das bandas do poliestireno cristal do substrato de um modo que não foi possível recuperálos, como pode ser visualizado na Figura 44 .

Figura 44 - Espectro Raman da (a) placa de Petri de poliestireno cristal na frequência de 3200 a $400 \mathrm{~cm}^{-1}$ adquirido nas condições em que os ensaios dos derivados acetilados foram realizados e o espectro Raman do (b) derivado $R A_{9}$ na frequência de 3200 a $400 \mathrm{~cm}^{-1}$ no qual as bandas do substrato predominaram.

(a)

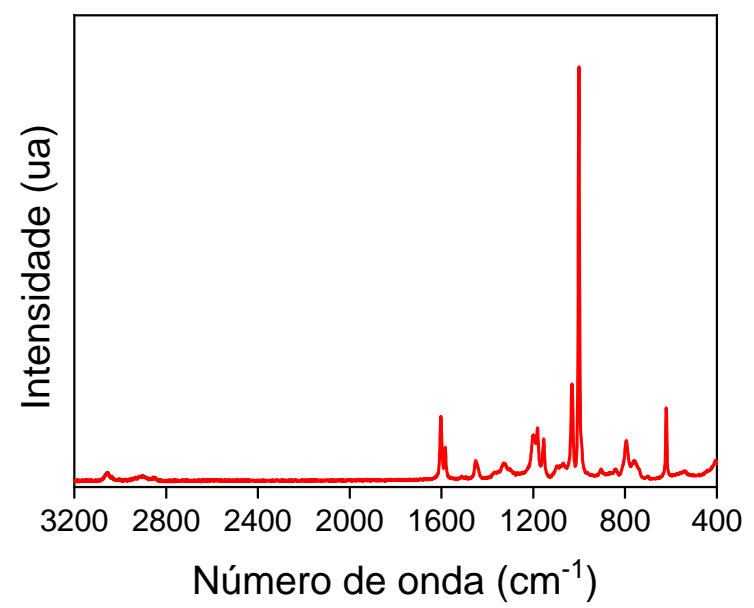

(b)

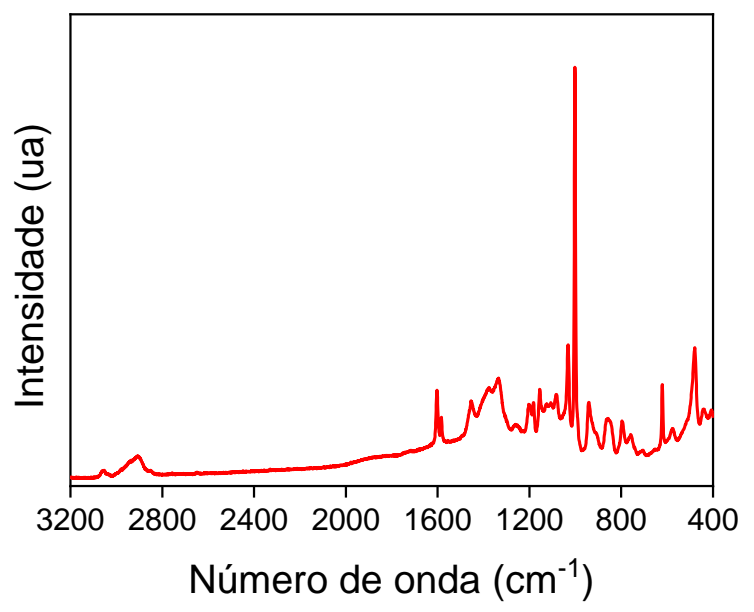

Fonte: Elaborado pela autora (2019).

$\mathrm{Na}$ Figura 44 (b) observa-se que apagar as bandas do poliestireno ou subtrair o espectro do poliestireno do espectro do derivados descaracterizaria o espectro vibracional do amido de mandioca.

Para o material do substrato ter interferido no espectro da amostra, duas situações podem ter ocorrido ou os géis de amido acetilado comportaram-se como se fossem meios transparentes e a luz atravessou a amostra, incidindo no substrato, ou os géis encolheram com o calor gerado pela luz, expondo o substrato ao feixe de luz.

Como isso não ocorreu com os géis dos derivados reticulados, a hidrólise ácida das moléculas dos derivados acetilados foi a causa da diminuição da intensidade do espalhamento Raman, visto que as ligações químicas quebraram.

Uma solução para evitar bandas do material do substrato no espectro da amostra teria sido usar folhas de alumínio como o próprio substrato. O espectro Raman do alumínio na frequência de 2000 a $400 \mathrm{~cm}^{-1}$ praticamente é uma reta em torno de valores baixos de intensidade que não interfeririam no espectro do amido de 
mandioca. Além disso, outra vantagem do alumínio é o seu espectro apresentar baixo ruído de fundo (BUTLER et al., 2016; CUI; BUTLER; MARTIN, 2016).

Dessa forma, o espectro dos derivados acetilados seria preservado e haveria evidência da quebra das ligações químicas nas moléculas do amido de mandioca. 


\section{CONCLUSÃo}

O estudo das condições do meio de reticulação e de acetilação do amido de mandioca mostrou que a reticulação é inibida por ânions fosfato, as condições do meio de reticulação comprometem a estrutura do grânulo e a acetilação diminui sua estabilidade.

A unidade química automatizada construída para conduzir os experimentos de síntese do amido modificado correspondeu ao propósito de monitorar o $\mathrm{pH}$ e a temperatura de reação com controle do $\mathrm{pH}$. Não houve perdas de derivados de amido de mandioca por causa do descontrole de $\mathrm{pH}$ e a repetibilidade das condições do meio de reação foi assegurada.

Reticular o amido de mandioca no pH 10,0 ou pH 11,0 e razão molar de trimetafosfato trisódio por unidade de anidroglicose de 0,03 ou 0,08 não alterou o perfil do $\mathrm{pH}$ do meio de reticulação ao longo do tempo de reação, denotando ausência de reticulação das moléculas do amido de mandioca.

Os grânulos dos derivados reticulados no pH 11,0 e razão molar de trimetafosfato trisódio por unidade de anidroglicose de 0,08 sofreram alteração física ou química. O provável é que os ânions $\mathrm{P}_{3} \mathrm{O}_{9}{ }^{3-}, \mathrm{P}_{2} \mathrm{O}_{7}{ }^{4-}$ ou $\mathrm{P}_{3} \mathrm{O}_{10}{ }^{5-}$ tenham deformado as moléculas do amido nas camadas mais externas devido à ação de forças eletrostáticas de repulsão que causaram o inchamento do grânulo. Os experimentos de síntese nessa condição foram perdidos.

A entalpia $(12,2 \pm 1,3) \mathrm{J} \mathrm{g}^{-1}$ e a temperatura $(63,6 \pm 0,4){ }^{\circ} \mathrm{C}$ de gelatinização dos derivados reticulados foram, em média, iguais.

Os espectros vibracionais de absorção no infravermelho exibiram o mesmo perfil, sem evidência de absorção de radiação nas frequências associadas com as ligações $(\mathrm{P}=\mathrm{O})$ e $(\mathrm{C}-\mathrm{P}-\mathrm{O})$ em grupos fosfato, em relação ao espectro do amido de mandioca nativo.

Os espectros Raman das moléculas gelatinizadas dos derivados reticulados não registraram transições em frequências associadas com as das ligações em grupos fosfato e as transições vibracionais das moléculas do amido permaneceram inalteradas mesmo após o inchamento, a fusão dos cristais de amilopectina e a solubilização do grânulo. 
Disto tudo, concluiu-se que os ânions fosfato presentes no meio de reticulação alteram o grânulo, levando ao inchamento e à gelatinização, e que as moléculas do amido de mandioca não reticulam nas condições estudadas.

$\mathrm{O}$ amido de mandioca reticulado foi acetilado na faixa desejada de $\mathrm{pH} 8,0$ a 8,5. A taxa de adição do anidrido acético controlada e constante reduziu o risco de hidrólise ácida das moléculas do amido. Nenhum experimento de síntese dos derivados acetilados de amido de mandioca foi perdido.

A entalpia $(10,8 \pm 0,4) \mathrm{J} \mathrm{g}^{-1}$ e a temperatura $(57,8 \pm 0,4)^{\circ} \mathrm{C}$ de gelatinização dos derivados acetilados foram, em média, iguais.

Comparando os derivados acetilados com os reticulados, a entalpia de gelatinização diminuiu sem alcançar significância estatística e a temperatura de gelatinização diminuiu significativamente.

Os espectros de absorção no infravermelho indicaram absorção de radiação em frequências associadas com o estiramento das ligações $(\mathrm{C}=\mathrm{O})$ e $(\mathrm{C}-\mathrm{O})$ de grupos acetila nas moléculas do amido e indicaram também absorção em frequência associada com a deformação das ligações $\left(-\mathrm{CH}_{3}\right)$ e $(\mathrm{O}-\mathrm{H})$ em ácidos carboxílicos.

Os espectros Raman das moléculas gelatinizadas dos derivados acetilados demonstraram perda de intensidade do espalhamento Raman devido à quebra das ligações químicas causada pela hidrólise ácida das moléculas do amido de mandioca.

A partir disto, concluiu-se que a acetilação das moléculas do amido de mandioca diminui a estabilidade térmica do grânulo devido ao abaixamento do ponto de fusão da amilopectina decorrente da presença de moléculas modificadas e hidrolisadas na fase fundida.

Sistemas amido-água com reação química e presença de ânions fosfato demostraram que as condições do meio de reação alteram o padrão de inchamento dos grânulos. Portanto, as condições do meio devem ser monitoradas e controladas, o que se torna imperativo se o propósito for obter derivados de amido para aplicações biomédicas. 


\section{SUGESTÕES PARA TRABALHOS FUTUROS}

I. Conduzir um estudo preliminar de viabilidade técnico-econômica sobre polissacarídeos empregados como biomateriais com ênfase em amidos para avaliar:

i. a possibilidade de usar um amido geneticamente modificado como matéria-prima - o amido de milho ceroso é utilizado na manufatura do expansor de plasma sanguíneo;

ii. a necessidade de alterar a arquitetura granular antes de proceder com a modificação química das moléculas_padronização da massa molecular média do derivado por meio da hidrólise controlada das moléculas;

iii. a possibilidade de empregar rotas limpas de modificação do amido e com menor consumo de utilidades-esterificação das moléculas de amilopectina e amilose por enzimas e a utilização de líquidos iônicos como meio de reação;

iv. a relação valor e custo no desenvolvimento de um novo biomaterial com base no desempenho e na confiabilidade-produtos ou sistemas que garantam o diagnóstico ou o tratamento médico a custo reduzido e acessível;

v. as aplicações em áreas relacionadas-amidos quimicamente modificados poderiam ser comercializados como amido resistente ou alimento com atividade imunorreguladora.

II. Quantificar os grupos funcionais introduzidos nas moléculas do amido de mandioca, identificar as posições de substituição e quais são as moléculas preferencialmente modificadas e sua posição no grânulo, correlacionando essas informações com propriedades macroscópicas de interesse para aplicações biomédicas.

III. Aperfeiçoar e propor um protótipo, com cárater modular, da montagem experimental para ser utilizado em laboratórios de ensino e de pesquisa. Neste caso, ele auxiliaria a definir condições de reação na síntese de derivados e parâmetros de scale-up para projetar unidades de síntese de amido quimicamente modificado. 


\section{REFERÊNCIAS 1}

AGÊNCIA NACIONAL DE VIGILÂNCIA SANITÁRIA. Informação técnica. Medicamentos expansores de volume à base de hidroxietilamido (HES): Risco de danos renais e aumento de sangramento. Contraindicação de uso em pacientes nefropatas, pacientes com risco aumentado de sangramento, pacientes graves e aqueles com maior risco de retenção hídrica. ANVISA, Brasília, DF, 05 ago. 2013. Disponível em: < http://portal.anvisa.gov.br > Acesso em 30 jul. 2018.

. Alerta do Sistema Nacional de Vigilância Sanitária Gfarm no 06, de 05 de agosto de 2013. Anvisa alerta quanto às restrições da indicação e mudanças na bula dos produtos à base de hidroxietilamido (HES). ANVISA, Brasília, DF, 05 ago. 2013. Disponível em: < http://portal.anvisa.gov.br > Acesso em 30 jul. 2018.

AGUIAR, H.F. Desenvolvimento e caracterização de filme biodegradável à base de amido de mandioca como suporte de liberação de NO. 2014. 141p. Tese (Doutorado). Escola Politécnica, Universidade de São Paulo, 2014.

AI, Y.; JANE, J. Gelatinization and rheological properties of starch. Starch/Stärke, v. 67, n. $3-4$, p. $213-224,2015$.

ALSBERG, E.; ANDERSON, K. W.; ALBEIRUTI, A.; ROWLEY, J. A.; MOONEY, D. J. Engineering growing tissues, Proceedings of the National Academy of Sciences of the United States of America, v. 19, n. 99, p. 12025 - 12030, 2002.

AMERICAN SOCIETY FOR TESTING AND MATERIALS. Standard specification for reagent water - D1193 - 06. ASTM International, 2018. $6 p$

Standard practices for general techniques of infrared quantitative analysis E168 - 16. ASTM International. 2016. 18p.

Standard test method for transition temperatures and enthalpies of fusion and crystallization of polymers by differential scanning calorimetry - D3418 - 15. ASTM International. 2015. 7p.

Standard practice for general techniques for obtaining infrared spectra for qualitative analysis - E1252- 98. ASTM International. 2013. 13p.

International. 2013. 17p.

Standard practices for internal reflection spectroscopy - E573 - 01. ASTM

BEJENARU, A.; POPA, M.; DULONG, V.; PICTON, L.; LE CERF, D. Trisodium trimetaphosphate cross-linked xanthan networks: synthesis, swelling, loading and releasing behaviour. Polymer Bulletin, v. 62, n. 4, p. 525 - 538, 2009.

BERTOFT, E. On the building block and backbone concepts of amylopectin structure. Cereal Chemistry, v. 4, n. 90, p. $294-311,2013$.

On the nature of categories of chains in amylopectin and their connection to the super helix model. Carbohydrate Polymers, v. 57, n. 2, p. 211 - 224, 2004.

\footnotetext{
1 De acordo com a Associação Brasileira de Normas Técnicas (ABNT NBR 6023).
} 
BERTOFT, E.; ANNOR, G. A.; SHEN, X.; RUMPAGAPORN, P.; SEETHARAMAN, K.; HAMAKER, B. R. Small differences in amylopectin fine structure may explain large functional differences of starch. Carbohydrate Polymers, v. 140, p. $113-121,2016$.

BERTOFT, E.; LAOHAPHATANALERT, K.; PIYACHOMKWAN, K., CHATAKANONDA, P., SRIROTH, K. The fine structure of cassava starch amylopectin. Part 2: building block structure of clusters. International Journal of Biological Macromolecules, v.47, n.3, p. $325-335$, 2010.

BERTOFT, E., PIYACHOMKWAN, K., CHATAKANONDA, P., SRIROTH, K. Internal unit chain composition in amylopectins. Carbohydrate Polymers, v.74, n. 3, p. $527-543,2008$.

BESHEER, A.; HAUSE, G.; KRESSLER, J.; MÄDER, K. Hydrophobically modified hydroxyethyl starch: synthesis, characterization, and aqueous self-assembly into nanosized polymeric micelles and vesicles. Biomacromolecules, v. 8, n. 2, p. $359-367,2007$.

BILIADERIS, C. G. Structural transitions and related physical properties of starch. In: BEMILLER, J.; WHISTLER, R. (Ed.). Starch: Chemistry and Technology. 3rd ed. London: Academic Press, 2009, p. $293-372$.

BIODATA TOOLBOX: Data system coupled to chemometric algorithms that consequently stores spectra and related data. 2008. Kris de Gussem, Raman Spectroscopy Research Group, Department of Analytical Chemistry. Ghent University. Disponível em: < https://www.mathworks.com/matlabcentral/fileexchange/22068-biodata-toolbox > . Acesso em 30 mai. 2018.

BRUBACH, J. B.; MERMET, A.; FILABOZZI, A.; GERSCHEL, A.; ROY, R. Signatures of the hydrogen bonding in the infrared bands of water. The Journal of Chemical Physics, v. 122, n.18, p. 184509-1 - 184509-7, 2005.

BUTLER, H. J.; ASHTON, L.; BIRD B.; CINQUE, G.; CURTIS, K.; DORNEY, J.; ESMONDEWHITE, K.; FULLWOOD, N. J.; GARDNER, B.; MARTIN-HIRSCH; P. L.; WALSH, M. J.; MCAINSH, M. R.; STONE, N.; MARTIN, F. L. Using Raman spectroscopy to characterize biological materials. Nature Protocols, v. 11, n. 4, p. $664-687,2016$.

CALVERT, P. The structure of starch. Nature, v. 389, n. 6649, p. 338 - 339, 1997.

CHARNLEY, J. Anchorage of the femoral head prosthesis to the shaft of the femur. The Journal of Bone and Joint Surgery, v. 42B, n. 1, p. $28-30,1960$.

CHEN, Q.; YU, H.; WANG, L.; ULABDIN, Z.; CHEN, Y.; WANG, J.; ZHOU, W.; YANG, X.; KHAN, R. U.; ZHANG, H.; CHEN, X. Recent progress in chemical modification of starch and its applications. Royal Society of Chemistry, v. 5, n. 83, p. $67459-67474,2015$.

CHENG, C. J.; LIETJEN, G. T.; SAUCIER-SAWYER, J. K.; SALTZMAN, W. M. A holistic approach to targeting disease with polymeric nanoparticles. Nature Reviews Drug Discovery, v. 14, n. 5, p. $239-247,2015$. 
CHIU, C.; SOLAREK, D. Modification of Starches. In: BEMILLER, J.; WHISTLER, R. (Ed.). Starch: Chemistry and Technology. 3rd ed. London: Academic Press, 2009, p. $629-655$.

COOKE, D.; GIDLEY, M. Loss of crystalline and molecular order during starch gelatinization: on the origin of the enthalpic transition. Carbohydrate Research, v. 22, p. 103. - 112, 1992.

CORN PRODUCTS COMPANY. Ralph W. Kerr; Frank C. Cleveland Jr. Thickening agent and method of making the same. US 3021222, 13 feb. 1962.

CUI, L.; BUTLER, H. J.; MARTIN, F. L. Aluminium foil as potential substrate for ATR-FTIR, transflection FTIR or Raman spectrochemical analysis of biological specimens. Analytical Methods, v. 8, n.3, p. $481-487,2016$.

DEUTSCHES INSTITUT FÜR NORMUNG. Starch - Determination of moisture content by oven-drying method (ISO 1666:1996) - DIN EN ISO 1666:1997- 01. DIN, 1998. 5p

DULONG, V.; FORBICE, R.; CONDAMINE, E.; LE CERF, D.; PICTON, L. Pullulan-STMP hydrogels: a way to correlate cross-linking mechanism, structure and physicochemical properties. Polymer Bulletin, v. 67, n. 3, p. 455 - 466, 2011.

EUROPEAN MEDICINES AGENCY. Pharmacovigilance Risk Assessment Committee recommends suspending marketing authorisations for infusion solutions containing hydroxyethyl starch. EMA, London, UK, 14 jun. 2013. Disponível em:

$<$ http://www.ema.europa.eu/docs/en GB/document library/Referrals document > Acesso em 07 ago. 2018.

Press release. Hydroxytheyl-starch solution (HES) no longer to be used in patients with sepsis or burn injuries or in critically ill patients. EMA, London, UK, 19 dec. 2013. Disponível em:

$<$ http://www.ema.europa.eu/docs/en GB/document library/Referrals document > Acesso em 07 ago. 2018.

Press Release. Hydroxyethyl starch solutions: CMDh introduces new measures to protect patients. EMA, London, UK, 17 jul. 2018. Disponível em:

$<$ http://www.ema.europa.eu/docs/en GB/document library/Referrals document $>$. Acesso em 07 ago. 2018.

FISCH, M. R; KUMAR, S. Introduction to liquid crystals. In: KUMAR, S. (Ed.). Introduction to liquid crystals. 1st ed. Cambridge: Cambridge University Press, 2001, p. 1 - 28.

FLORY, P. J. Principles of polymer chemistry. $6^{\text {th }}$ ed. Ithaca: Cornell University Press, 1953. Molecular theory of liquid crystals . In: GORDON, M. R.; PLATE, N. A. (Ed.). Advances in polymer science. New York: Springer-Verlag, 1984, v. 59, p. $1-36$. 
FOOD AND DRUG ADMINISTRATION. Safety communication. Boxed warning on increased mortality and severe renal injury, and additional warning on risk of bleeding, for use of hydroxyethyl starch solutions in some settings. FDA, Washington, DC, 24 jun. 2013. Disponível em: < http://www.fda.gov > Acesso em 30 jul. 2018.

\section{Select committee on GRAS substances database.}

Disponível em: <http://www.accessdata.fda.gov/scripts/fdcc/?set=SCOGS> Acesso em: 20 nov. 2017.

GALAS, J.; HAGHIRI-GOSNET, A.; ESTÉVEZ-TORRES, A. A nanoliter-scale open chemical reactor. Lab on a Chip, v. 13, n. 3, p. $415-423,2013$.

GATTA, G. D.; RICHARDSON, M. J.; SARGE, S. M.; STOLEN, S. Standards, calibration, and guidelines in microcalorimetry. Part 2. Calibration standards for differential scanning calorimetry (IUPAC technical report). Pure and Applied Chemistry, v. 78, n. 7, p. 1455 1476, 2006.

GHIASI, K.; HOSENEY, R.C.; VARRIANO-MARSTON, E. Gelatinization of wheat starch. III. comparison by differential scanning calorimetry and light microscopy. Cereal Chemistry, v. 54, n. 4, p. $258-262,1982$.

GODET, M. C.; BOUCHET, B.; COLONNA, P.; GALLANT, D. J.; BULÉON, A. Crystalline amylose - fatty acid complexes: morphology and crystal thickness. Journal of Food Science, v. 61, n. 6, p. 1196-1201, 1996.

GOLACHOWSKI, A.; ZIEBA, T.; KAPELKO-ZEBERSKA, M.; DROZDZ, A.; GRYSZKIN, A.; GRZECHAC, M. Current research addressing starch acetylation. Food Chemistry, v. 176, p. $350-356,2015$.

GOREN, A. Modelling amilopectin biosynthesis with evolved stigmergic building algorithms. 2017. 108p. Thesis (MSc). University of Guelph. 2017.

GOUGH, B. M.; PHYBUS, J. N. Effect of metal cations on the swelling and gelatinization behaviour of large wheat starch granules. Starch/Stärke, v. 25, n. 4, p. $123-130,1973$.

GRINIAS, J. P.; WHITFIELD, J. T.; GUESTCHOW, E. D.; KENNEDY. R. T. An expensive, open-source USB arduino data acquisition device for chemical instrumentation. Journal of Chemical Education, v. 93, n.7, p. 1316 - 1319, 2016.

HAN, F.; LIU, M.; GONG, H.; LÜ, S.; N, BO.; ZHANG, B. Synthesis, characterization and functional properties of low substituted acetylated corn starch. International Journal of Macromolecules, v. 50, n. 4, p. 1026 - 1034, 2012. 
lymph-node metastases in prostate cancer. The New England Journal of Medicine, v. 348, n. 25, p. $2491-2499,2003$.

HARTOG, C. S.; KOHL, M.; REINHART, K. A systematic review of third-generation hydroxyethyl starch (HES 130/0.4) in ressuscitation: safety not adequately addressed. Anesthesia \& Analgesia, v. 112, n. 3, p. $635-645,2011$.

HEINZE, T.; LIEBERT, T.; KOSCHELLA, A. Esterification of polysaccharides. 1st ed. Berlin: Springer, 2006.

HIZUKURI, S. Relationship between the distribution of the chain length of amylopectin and the crystalline structure of starch granules. Carbohydrate Research, v. 141, n. 2, p. $295-306$, 1985.

Polymodal distribution of the chain lengths of amylopectin, and its significance. Carbohydrate Research, v. 147, n.2, p. 342 - 347, 1986.

HIZUKURI, S.; KANEKO, T.; TAKEDA, Y. Measurement of the chain length of amylopectin and its relevance to the origin of crystalline polymorphism of starch granules. Biochimia et Biophysica Acta, v. 760, n.1, p. 188 - 191, 1983.

HUANG, P. V.; SCHOLS, H. A.; KLAVER, R.; JIN, Z.; VORAGEN, A. G. J. Acetyl substitution patterns of amylose and amylopectin populations on cowpea starch modified with acetic anhydride and vinyl acetate. Carbohydrate Polymers, v. 67, n.4, p. 542 - 550, 2006.

HUNG, P. V.; MORITA, N. Effects of granule sizes in physicochemical properties of crosslinked and acetylated wheat starches. Starch/Stärke, v. 57, n.9, p. 413 - 420, 2005.

JANE, J. Mechanism of starch gelatinization in neutral salt solutions. Starch/Stärke, v.45, n. 5, p. $161-166,1993$.

Structural features of starch granules II. In: BEMILLER, J.; WHISTLER, R. (Ed.). Starch: Chemistry and Technology. 3rd ed. London: Academic Press, 2009, p. $193-236$.

JANE, J.; XU, A.; RADOSAVLJEVIC, F.; SEIB, P. A. Location of amylose in normal starch granules. I. Susceptibility of amylose and amylopectin to cross-linking reagents. Cereal Chemistry, v.69, n. 4, p. $405-409,1992$.

JAROWENKO, W. Acetylated starch and miscellaneous organic esters. In: WURZBURG, O. B. (Ed.). Modified starches: properties and uses. 1st ed. CRC Press, 1986, p. $55-77$.

JARVIS, P.; LÓPEZ-JUEZ, E. Biogenesis and homeostasis of chloroplasts and other plastids. Nature Reviews Molecular Cell Biology, v.14, n.2, p. 787 - 802, 2013. 
JETTEN, W.; STAMHUIS, E. J.; JOOSTEN, G. E. H. Acetylation of potato starch to a low degree of substitution. Starch/Stärke, v.32, n.11, p. $364-368,1980$.

JUSZCZAK, L.; FORTUNA, T.; KROK, F. Non-contact atomic force microscopy of starch granules surface. Part I. potato and tapioca starches. Starch/Stärke, v.55, n.1, p. 1 - 7, 2003.

KALKMAN, C. J. LabView: a software system for data acquisition, data analysis, and instrument control. Journal of Clinical Monitoring, v. 11, n. 1, p. $51-58,1995$.

KASEMSUWAN, T.; BAILEY, T.; JANE, J. Preparation of clear noodles with mixtures of tapioca and high-amylose starches. Carbohydrate Polymers, v.32, n.4, p. $301-312,1998$.

KASEMSUWAN, T.; JANE, J. Location of amylose in normal starch granules. II. Location of phosphodiester cross-linking revealed by phosphorus - 31P nuclear magnetic resonance. Cereal Chemistry, v.71, n. 3, p. $282-287,1994$.

KNORPP, C. T.; MERCHANT, W. R.; GIKAS, P. W.; SPENCER, H. H.; THOMPSON, N. W. Hydroxyethyl starch: extracellular cryophylactic agent for erythrocytes, Science, v. 157, n. 3794, p. $1312-11313,1967$.

KUPFERSCHMIDT, K. Squabble over NEJM paper puts spotlight on antishock drug. Science News. Washington, 2 Aug. 2012.

Disponível em: <http://www.sciencemag.org/news/2012/08/squabble-over-nejm-paper-putsspotlight-antishock-drug >. Acesso em: 28 jul. 2018.

Antishock drug may be dangerous. Science News. Washington, 16 Oct. 2012. Disponível em:

< http://www.sciencemag.org/news/2012/10/antishock-drug-may-be-dangerous > Acesso em: 28 jul. 2018.

KWON, E. J.; LO, J. H.; BHATIA, S. N. Smart nanosystems: bio-inspired technologies that interact with the host environment. Proceedings of the National Academy of Sciences of the United States of America, v. 112, n. 47, p. 14460 - 14466, 2015.

LACK, S.; DULONG, V.; PICTON, L.; LE CERF, D.; CONDAMINE, E. High-resolution nuclear magnetic resonance spectroscopy studies of polysaccharides cross-linked by sodium trimetaphosphate: proposal for the reaction mechanism. Carbohydrate Research, v. 324, n.7, p. $943-953,2007$.

LANGER, R.; TIRRELL, D. A. Designing materials for biology and medicine. Nature, v. 428, n. 6982 , p. $487-492,2004$.

LECHERT, H.T. Water binding on starch: NMR studies on native and gelatinized starch. In: 
ROCKLAND, L. B.; STEWART, G. F. (Ed.). Water activity: influences on food quality. 3rd ed. New York: Academic Press, 1981, p. $223-245$.

LEVER, T.; HAINES, P.; ROUQUEROL, J.; CHARSLEY, E. L.; VAN ECKEREN, P.; BURLETT, D. J. ICTAC nomenclature of thermal analysis (IUPAC Recommendations 2014). Pure and Applied Chemistry, v. 86, n. 4, p. 545 - 553, 2014.

MABBOTT, G. A. Teaching electronics and laboratory automation using microcontroller boards. Journal of Chemical Education, v. 91, n. 9, p. $1458-1463,2014$.

MARIJNISSEN, W. J. C. M.; VAN OSCH, G. J. V. M.; AIGNER, J.; VAN DER VEEN, S. W.; HOLLANDER, A. P.; VERWOERD-VERHOEF, H. L.; VERHAAR, J. A. N. Alginate as a chondrocyte delivery substance in combination with a non-woven scaffold for cartilage tissue engineering. Biomaterials, v. 23, n. 6, p. 1511 - 1517, 2002.

MASINA, N.; CHOONARA, Y. E.; KUMAR, P.; DU TOIT, L. C.; GOVENDER, M.; INDERMUN, S.; PILLAY, V. A review of the chemical modification techniques of starch. Carbohydrate Polymers, v. 157, p. $1226-1236,2017$.

MCCULLEN, S. D.; CHOW, A. G.; STEVENS, M. M. In vivo tissue engineering of musculoskeletal tissues. Current Opinion in Biotechnology, v. 22, n.5, p. $715-720,2011$.

MIZRAHY, S.; PEER, D. Polysaccharides as building blocks for nanotherapeutics. Chemical Society Reviews, v. 41, n. 7, p. 2623 - 2640, 2012.

MOSER, K. B. Hydroxyethylated starches. In: WURZBURG, O. B. Modified starches: properties and uses. CRC Press, ed. 1, p. $79-88,1986$.

MYBURGH, J.A.; FINFER, S.; BELLOMO, R.; BILLOT, L.; CASS, A.; GATTAS, D.; GLASS, P.; LIPMAN, J.; LIU, B.; MCARTHUR, C.; MCGUINNESS, S.; RAJBHANDARI, D.; TAYLOR, C. B.; WEBB, S. A. R. Hydroxyethyl starch or saline for fluid resuscitaton in intensive care. The New England Journal of Medicine, v. 367, n. 20, p. $1901-1911,2012$.

Hydroxyethyl starch or saline for fluid resuscitaton in intensive care. The New England Journal of Medicine, v. 374, n.13, p.1298, 2016.

NEUBERT, M. E. Characterization of mesophase types and transitions. In: KUMAR, S. (Ed.). Introduction to liquid crystals. 1st ed. Cambridge: Cambridge University Press, 2001, p. 29 -64 .

NORDSTOKKE, D. W.; ZUMBO, B. D. A new nonparametric Levene test for equal variances. Psicológica, v.31, n.2, p. $401-430,2010$. 
temperature of starches in water. Starch/Stärke, v.34, n. 7, p. $233-239,1982$.

1990.

Interactions between starch and electrolytes. Starch/Stärke, v. 42, n. 9, p. 327 - 330,

OOSTERGETEL, G. T.; VAN BRUGGEN, E. F. J. The crystalline domains in potato starch granules are arranged in a helical fashion. Carbohydrate Polymers, v. 21, n. 1, p. $7-12$, 1993.

PAVIA, D.L.; LAMPMAN, G. M.; KRIZ, G. S.; VYVYAN, J. R. Introduction to spectroscopy. 4th ed. Belmonte: Cengage Learning, 2009.

PEARCE, J. M. Cut costs with open-source hardware. Nature, v. 505, n. 7485, p. 618, 2014.

PEER, D.; KARP, J.M.; HONG, A.; FAROKHZAD, O. C.; MARGALIT, R.; LANGER, R. Nanocarriers as an emerging platform for cancer therapy. Nature Nanotechnology, v. 2, n.12, p. $751-760,2007$.

PHILLIPS, D. L.; LIU, H.; PAN, D.; CORKE, H. General application of raman spectroscopy for the determination of level of acetylation in modified starches. Cereal Chemistry, v. 76, n. 3, p. $439-443,1999$.

PEK, Y. S.; WAN, A. C. A.; SHEKARAN, A.; ZHUO, L.; YING, J. Y. A thixotropic nanocomposite gel for three-dimensional cell culture. Nature Nanotechnology, v. 3, n.11, p. $671-675,2008$.

PÉREZ, S.; BALDWIN, P. M.; GALLANT, D. J. Structural features of starch granules I In: BEMILLER, J.; WHISTLER, R. (Ed.). Starch: Chemistry and Technology. 3rd ed. London: Academic Press, 2009, p. $149-192$.

PÉREZ, S.; BERTOFT, E. The molecular structures of starch component and their contribution to the architecture of starch granules: a comprehensive review. Starch/Stärke, v. 62, n.8, p. $389-420,2010$.

RAGUIN, A.; EBENHOH , O. Design starch: stochastic modeling of starch granule biogenesis. Biochemical Society Transactions, v. 45, n. 4, p. $885-893,2017$.

RANDZIO, S. L.; FLIS-KABULSKA, I.; GROLIER, J. E. Reexamination of phase transformations in the starch-water system. Macromolecules, v. 35, n. 23, p. $8825-8859$, 2002.

RATNER, B. D. Healing with medical implants: the body battles back. Science Translational Medicine, v. 7, n. 272, p. $1-4,2015$.

RYCERZ, L. Practical remarks concerning phase diagrams determination on the basis of 
differential scanning calorimetry measurements. Journal of Thermal Analysis and Calorimetry, v. 113, n. 1, p. $231-238,2013$.

SALA, O. Fundamentos da espectroscopia Raman e no infravermelho. 2 ed. São Paulo: Editora Unesp, 2008.

.$I_{2}$ - uma molécula didática. Química Nova, v. 31, n. 4, p. 914 - 920, 2008.

SHAH, A. M.; JUNG, H.; SKIRBOLL, D. Materials used in cranioplasty: a history and analysis. Neurosurgical Focus, v. 36, n. 4, p. 1-7, 2014.

SILVERSTEIN, R. M.; BASSLER, G. C.; MORRIL, T. C. Spectrometric identification of organic compounds. 3rd ed. New York: Wiley, 1974.

1991.

Spectrometric identification of organic compounds. 5th ed. New York: Wiley,

SINGH, N.; CHAWLA, D.; SINGH, J. Influence of acetic anhydride on physicochemical, morphological and thermal properties of corn and potato starch. Food Chemistry, v. 86, n. 4, p. $601-608,2004$.

SINGH, J.; KAUR, D.; MCCARTHY, O. J. Factors influencing the physico-chemical, morphological, thermal and rheological properties of some chemically modified starches for food applications-a review. Food Hydrocolloids, v. 21, n. 1, p. 1 - 22, 2007.

SLEIGHTHOLM, R.; YANG, B.; YU, F.; XIE, Y.; OUPICKY, D. Chloroquine-modified hydroxyethyl starch as a polymeric drug for cancer therapy. Biomacromolecules, v. 18, n. 8, p. $2247-2257,2017$.

STEVENS, M. M.; MARIANI, R. P.; SCHAEFER, D.; ARONSON, J.; LANGER, R.; SHASTRI, $V$. P. In vivo engineering of organs: The bone bioreactor, Proceedings of the National Academy of Sciences of the United States of America, v. 102, n.32, p. $11450-11455$, 2005.

TIBBITT, M. W.; LANGER, R. Living biomaterials. Accounts of Chemical Research, v. 50, n. 3 , p. $508-513,2017$.

TOLLEMAR, V.; COLLIER, Z. J.;MOHAMMED, M. K.; LEE, M. J; AMEER, G. A.; REID, R. R. Stem cells, growth factors and scaffolds in craniofacial regenerative medicine, Genes \& Diseases, v. 3, n. 1, p. $56-71,2016$.

TREIB, J.; HAASS, G. P.; PINDUR, G.; GRAUER, M. T.; WENZEL, E.; SCHIMRICK, K. All medium starches are not the same: influence of the degree of hydroxyethyl substitution of hydroxyethyl starch on plasma volume, hemorrheologic conditions, and coagulation. 
Transfusion, v. 36, n. 5, p. $450-455,1996$.

VAMADEVAN, V.; BERTOFT, E. Structure-function relationships of starch components. Starch/Stärke, v. 67, n. $1-2$, p. $55-68,2015$.

VAMADEVAN, V.; BERTOFT, E.; SOLDATOV, D. V.; SEETHARAMAN, K. Impact on molecular organization of amylopectin in starch granules upon annealing. Carbohydrate Polymers, v. 98, n. 1, p. 1045 - 1055, 2013.

VAUX, D. L.; FIDLER, F.; CUMMING, G. Replicates and repeats-what is the difference and is it significant? A brief discussion of statistics and experimental design. Science and Society, v. 13, n. 4, p. $291-296,2012$.

WANG, S.; LI, C.; ZHANG, X.; COPELAND, L.; WANG, S. Retrogradation enthalpy does not always reflect the retrogradation behavior of gelatinized starch. Scientific Reports, v. 6, p. 1 $-10,2016$.

WARREN, F. J.; PERSTON, B. P.; ROYALL, P. G.; BUTTERWORTH, P. J.; ELLIS, P. R. Infrared spectroscopy with heated attenuated total internal reflectance enabling precise measurement of thermally induced transitions in complex biological polymers. Analytical Chemistry, v. 85, n. 8, p. $3999-4006,2013$.

WILLIAMS, D. F. On the mechanisms of biocompatibility. Biomaterials, v. 29, n. 20, p. 2941 - 2953, 2008.

WILSON, J. T. A sweeter approach to vaccine design - glycoengineering may improve nextgeneration vaccines and immunotherapies, Science, v. 363, n. 6427, p. 584', 2019.

WINKLER, T.; SASS, F. A.; DUDA, G. N.; SCHMIDT-BLEEK, K. A review of biomaterials in bone defect healing, remaining shortcomings and future opportunities for bone tissue engineering -the unsolved challenge. Bone Joint Research, v. 7, n. 3 p. $232-243,2018$.

WOJDYR, M. Fityk: a general-purpose peak fitting program. Journal of Applied Crystallography, v. 43, p. $1126-1128,2010$.

WONGSAGONSUP, R.; PUJCHAKARN, T.; JITRAKBUMRUNG, S.; CHAIWAT, W.; FUONGFUCHAT, A.; VARAVINIT, S.; DANGTIP, S.; SUPHANTHARIKA, M. Effect of crosslinking on physicochemical properties of tapioca starch and its application in soup products. Carbohydrate Polymers, v. 101, p. 656 - 665, 2014.

WOO, K. S.; SEIB, P. A. Cross-linking of wheat starch and hydroxypropylated wheat starch in alkaline slurry with sodium trimetaphosphate. Carbohydrate Polymers, v. 33, n. 4, p. $263-271,1997$. 
n. 6, p. $819-825,2002$.

WURZBURG, O. B. Cross-linked starches. In: Modified starches: properties and uses. CRC Press, ed. 1, p. $41-53,1986$.

ZARYCHANSKI, R.; ABOU-SETTA, A. M.; TURGEON, A. F.; HOUSTON, B. L.; MCINTYRE, L.; MARSHALL, J.C.; FEGUSSON, D. A. Association of hydroxyethyl starch administration with mortality and acute kidney injury in critically ill patients requiring volume resuscitation: a systematic review and meta-analysis. Journal of American Medical Association, v. 309, n. 7 , p. $678-688,2013$.

ZHAO, K.; LI, D.; XU, W.; DING, J.; JIANG, W.; LI, M.; WANG, C.; CHEN, X. Targeted hydroxyethyl starch prodrug for inhibiting the growth and metastasis of prostate cancer. Biomaterials, v. 116, p. $82-94,2017$.

ZOBEL, H. F. Starch crystal transformations and their industrial importance. Starch/Stärke, v. 40, n. 1 , p. $1-7,1988$. 